DOE/EIA - 0523(90/2Q)

Distribution Category UC-98

\title{
International Oil and Gas Exploration and Development Activities
}

\author{
Quarterly Report \\ April - June 1990
}

DOE/E IA- $-0523(90 / 2 Q)$

DE91 002442

\author{
Energy Information Administration \\ Office of Oil and Gas \\ U.S. Department of Energy \\ Washington, D.C. 20585
}

This report was prepared by the Energy Information Administration, the independent statistical and analytical agency within the Department of Energy. The information contained herein should not be construed as advocating or rel'ecting any policy position of the Department of Energy or any other organization. 


\section{Preface}

This report is pirt of a serie's of quarterly publications prepared by the Energy Information Administration (EIA) in response to the world's rapidly changing oil supply. The series began with the fourth quarter of 1988. It was developed to provide interested analysts with a single source for monitoring international oil and gas exploration and development activities. The systemattic compilation of oil industry activities provides a means for tracking the location and magnitude of significant discoveries which will yield our future supplies of oil and natural gas. Specific information regarding the preparation or contents of this puhlicattion may be obtained from John H. Wood or Gary R. Long of the EIA Dallas Field Office, telephone $214 / 767-22(k)$. 


\section{Contents}

Page

Introduction $\ldots \ldots \ldots \ldots \ldots \ldots \ldots \ldots \ldots \ldots \ldots \ldots \ldots \ldots \ldots \ldots \ldots \ldots \ldots \ldots \ldots$

Overview $\ldots \ldots \ldots \ldots \ldots \ldots \ldots \ldots \ldots \ldots \ldots \ldots \ldots \ldots \ldots \ldots \ldots \ldots \ldots \ldots \ldots \ldots$

Reserve Additions for the 2 nd Quarter $1990 \ldots \ldots \ldots \ldots \ldots \ldots \ldots \ldots \ldots \ldots$

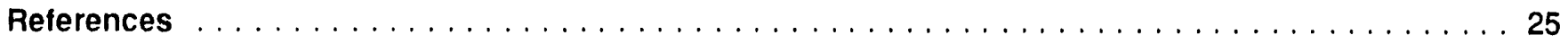

\section{Appendices}

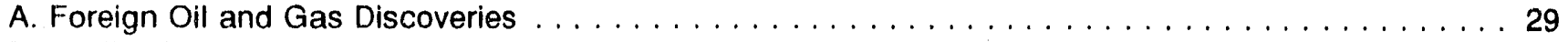

B. Modified Petroconsultants Reserve Additions $\ldots \ldots \ldots \ldots \ldots \ldots \ldots \ldots \ldots \ldots \ldots \ldots \ldots \ldots$

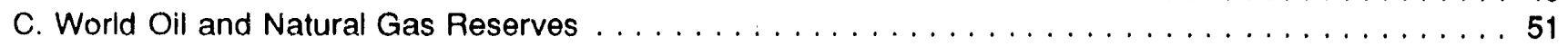

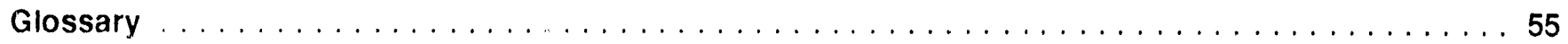

\section{Tables}

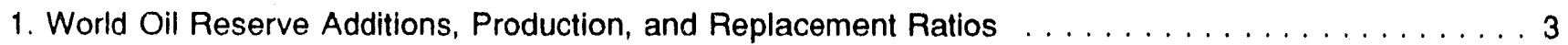

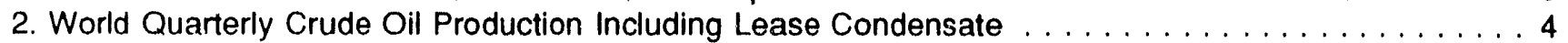

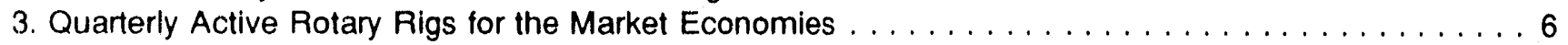

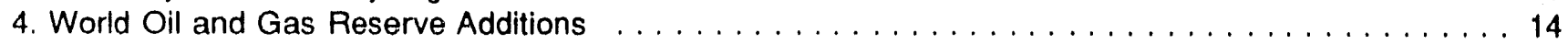

\section{Figures}

1. World Average Daily Crude Oil Production Including Lease Condensate $\ldots \ldots \ldots \ldots \ldots \ldots \ldots$

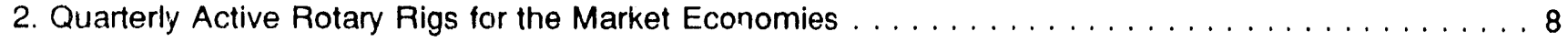

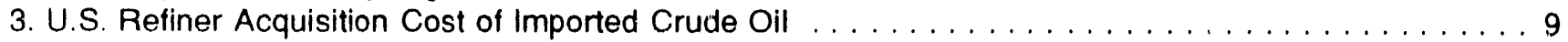

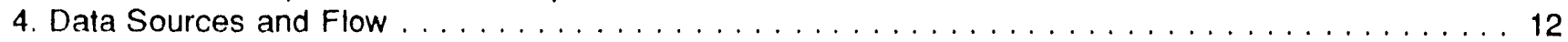

5. European Reserve Additions for the 2nd Quarter $1990 \ldots \ldots \ldots \ldots \ldots \ldots \ldots \ldots \ldots \ldots \ldots$

6. Asian, U.S.S.R., and Middle Eastern Reserve Additions for the 2nd Quarter $1990 \ldots \ldots \ldots \ldots \ldots$

7. African Reserve Additions for the 2nd Quarter $1990 \ldots \ldots \ldots \ldots \ldots \ldots \ldots \ldots \ldots \ldots$

8. Oceanian Reserve Additions for the 2nd Quarter $1990 \ldots \ldots \ldots \ldots \ldots \ldots \ldots \ldots \ldots \ldots$ 


\section{Introduction}

This report is part of an ongoing series of quarterly publications that monitors discoveries of oil and natural gas in foreign countries and provides an analysis of the reserve additions that result. The report is prepared by the Energy Information Administration (EIA) of the U.S. Department of Energy (DOE) under the Foreign Energy Supply Assessment Program (FESAP). It presents a summary of discoveries and reserve additions that result from recent international exploration and development activities. It is intended for use by petroleum industry analysts, various government agencies, and political leaders in the development, implementation, and evaluation of energy plans, policy, and legislation.

A discovery, as used in this publication, is a published estimate of the ultimately recoverable reserves for either a new field, reservoir, or well. This ultimate recovery is defined in this report as cumulative production plus remaining reserves. These discoveries are obtained from various oil industry periodicals and company annual or quarterly reports. The discoveries are not verified by EIA but simply restated in this publication. The reported reserves do not necessarily follow the EIA definition of proved reserves. Each reserve entry follows the defining criteria of the originator. These reserve definitions may be less restrictive than the definition used by EIA. It is important to keep in mind that not all discoveries are announced and not all announced discoveries are published. Some discoveries may be exaggerated or understated for political or other reasons. Therefore, the data in this report should be used with caution.

There are 4 tables and 3 figures showing oil production, oil and gas reserve additions, active rotary rigs, and crude oil prices. The data are given by country or group of countries such as the Organization of Petroleum Exporting Countries (OPEC), the Non-OPEC Market Economies (Non-OPEC ME), and the Centrally Planned Economies (CPE). A few of the more significant discoveries are discussed in this report, and their approximate locations are shown on four continental maps. The appendices list discoveries reported in industry periodicals and company reports, Petroconsultants oil and gas reserve additions, remaining oil and gas reserves, and a glossary of abbreviations.

Note: The information in this report was compiled as of the end of June 1990, about a month prior to the Irayi invasion of Kuwait. Since that time, the United Nations has imposed an embargo on imports and exports of Iray and Kuwait, and world oil prices have soared. 


\section{Overview}

\section{Oil Reserve Additions}

World oil reserve additions have more than replaced production for the last 12 -month and 36-month pericds ending in June 1990. For tne last 12 months, the Non-OPEC Market Economies (Non-OPEC ME) and Centrally Planned liconomies (CPE) each added more oil reserves than were produced while OPEC was even. World reserve additions ware 32.2 billion barrels and production was 22.2 billion barrels of oil, a replacement ratio of 1.5:1 (Table 1). Similarly, reserve additions for the Non-()PEC ME were 9.8 billion barrels while production was 8.2 billion barrels of oil which yielded a replacement ratio of 1.2:1. The reserve replacement ratio for OPEC was 1.0:1 for the last 12 months. The CPE had a replacement ratio of 2.7:1. The CPE replacement ratio would have been 1.9:1 except for the upward revision of 4 billion barrels in the past 12 months for the Tengiz. field in the U.S.S.R.(Appendix A). For the last 36 months, world reserve additions were 243 billion barrels and production was 65 billion barrels of oil, a replacement ratio of 3.7:1. Also, for the last 36 months, the Non-OPEC ME had a replacement ratio of $2.3: 1$, while OPEC and CPE countries had ratios of 6.4:1 and 1.9:1, respectively.

Compared to last quarter's report for the last 12 months, reserve additions are lower for the world, OPEC, and Non-OPEC ME. Reserve additions are higher for the CPE. Production for the last 12 months is slightly higher for the world, OPEC, and Non-OPEC ME, but lower for the CPE. Replacement ratios are the same for the world, lower for OPEC and Non-OPEC ME, and higher for the CPE. The U.S.S.R. has the highest reserve additions in the last 12 months at 8.7 billion barrels of oil (Table 4).

Compared to last quarter's report for the liw, 36 months, reserve additions are lower for the world and OPEC, and higher for Non-OPEC ME arid CPE. Production is higher for the world and OPEC, but lower for the Non-OPEC ME and CPE. Replacement ratios are lower for the world and OPEC, and steady for the Non-OPEC ME and CPE. Countries with reserve additions over 10 billion barrels in the last 36 months are: Mexico (19.2), Venezuela (21.3), U.S.S.R. (19.4), Abu Dhabi (27.9), Iran (25.7), iray (49.6), Kuwait (17.9), Saudi Arabia (11.8), and China (12.7) (Table 4).

Table 1. World Oil Reserve Additions, Production, and Replacement Ratios

\begin{tabular}{|c|c|c|c|c|}
\hline \multirow{2}{*}{ Category } & \multirow[b]{2}{*}{ World } & \multicolumn{3}{|c|}{ Non-OPEC } \\
\hline & & OPEC & ME & CPE \\
\hline & \multicolumn{4}{|c|}{$\begin{array}{c}\text { Last } 36 \text { Months } \\
7 / 87-6 / 90 \\
\end{array}$} \\
\hline Reported Reserve Additions (MMbbls) & 242,557 & 153,597 & 57,790 & 31,170 \\
\hline Production (MMbbis) & 64,772 & 24,010 & 24,727 & 16,034 \\
\hline Net Reserve Additions (MMbbls) ${ }^{\prime}$ & 177,785 & 129,587 & 33,063 & 15,136 \\
\hline \multirow[t]{2}{*}{ Replacement Ratio ${ }^{2}$} & $\ldots 3.7$ & 6.4 & 2.3 & 1.9 \\
\hline & \multicolumn{4}{|c|}{$\begin{array}{c}\text { Last } 12 \text { Months } \\
7 / 89-6 / 90\end{array}$} \\
\hline Reported Reserve Additions (MMbbls) & 32,186 & 8,493 & 9,803 & 13,890 \\
\hline Production (MMbbls) ....... & 22,162 & 8,730 & 8,195 & 5,236 \\
\hline Net Reserve Additions (MMbbls) ${ }^{1}$ & ${ }^{1} 0,024$ & -237 & 1,608 & 8,654 \\
\hline Replacement Patio? & .1 .5 & 1.0 & 1.2 & 2.7 \\
\hline
\end{tabular}

'Net Reseive Additions - Reported reserve additions minus production

"Replacement Ratio :- Reported reserve additions divided by production

Note. A listing of OPEC, CPE, and ME countries is contained in the Glossary

Source Reserve additions are derived from Table 4 . Production is derived from Tabla 2. 


\section{Production}

OPEC oil production for the second quarter of 1990 is estimated at 24.3 million barrels per day (Table 2.). This estimate is 2.1 million barrels per day more than was produced in the second quarter of 1989 , slightly more than was produced in the first quarter 1990, and 1.6 million barrels per day above the new OPEC crude oil quota of 22.6 million barrels of crude oil per day. The new quota was in effect from May through July 1990. Non-OPEC ME production increased 384,000 barrels of oil per day compared to the second quarter of 1989 and dropped 184,000 barrels per day ( 0.8 percent) compared to the first quarter 1990. CPE production has been declining through 1989 and the first half of 1990. Compared to the second quarter of 1989. CPE production is 345,000 barrels of oil per day less. CPE oil production is 190,000 barrels per day less than in the first quarter of 1990). Compared to 1 year earlier, production in the second quarter of 1990 is 3.7 percent higher for the world, 9.5 percent higher for OPEC, 1.7 percent higher for the Non-OPEC ME, and 2.4 percent lower for the CPE.

Table 2. World Quarterly Crude OII Production Including Lease Condensate (Milliori Barrels per Day)

\begin{tabular}{ccccc}
\hline Qtr/Year & World & OPEC & $\begin{array}{c}\text { Non-OPEC } \\
\text { ME }\end{array}$ & CPE \\
\hline 1st/1987 & 54.581 & 17.150 & 22.664 & 14.767 \\
2nd/1987 & 54.969 & 17.798 & 22.404 & 14.767 \\
3rd/1987 & 57.924 & 20.452 & 22.601 & 14.870 \\
4th/1987 & 57.699 & 19.935 & 22.974 & 14.790 \\
Annual Average $\ldots \ldots$ & 56.306 & 18.846 & 22.661 & 14.799 \\
& & & & \\
1st/1988 & 57.043 & 18.984 & 23.249 & 14.811 \\
2nd/1988 & 57.333 & 19.783 & 22.769 & 14.782 \\
3rd/1988 & 58.349 & 21.123 & 22.420 & 14.806 \\
4th/1988 & 61.105 & 23.674 & 22.551 & 14.880 \\
Annual Average $\ldots .$. & 58.464 & 20.899 & 22.746 & 14.820 \\
1st/1989 & & & & \\
2nd $/ 1989$ & 58.181 & 21.101 & 22.347 & 14.733 \\
3rd/1989 & 58.668 & 22.155 & 22.010 & 14.503 \\
4th/1989 & 59.814 & 23.012 & 22.300 & 14.502 \\
Annual Average $\ldots \ldots$ & 59.461 & 22.634 & 22.300 & 14.370 \\
& & & & 14.526 \\
1st/1990 & 61.105 & 24.179 & 22.578 & 14.348 \\
2nd/1990' & 60.815 & 24.263 & 22.394 & 14.158 \\
\hline
\end{tabular}

'Production data for the second quarter 1990 are ElA estimates.

Note: A listing of OPEC, CPE, and ME countries is contained in the Glossary. Data for 1989 and 1990 have been revised.

Source: Energy Information Administration, Monthly Energy Review, DOE/EIA-0035(90/04).

Beginning in 1986, Non-OPEC ME production leveled off while OPEC production, and thus world production, rose (Figure 1). OPEC production exceeded Non-OPEC ME production in the fourth quarter of 1988 and from the second quarter of 1989 forward. OPEC's share of world production peaked in 1973 at 55.6 percent. The OPEC share then declined to 31 percent in 198.5 and increased to 38.1 percent in 1989 and 39.9 percent in the second quarter of 1990.

\section{New Production Quotas}

The (OPEC crude oil production quota at the start of 199() was 22.086 million barrels of crude oil per day. Beginning in May, OPEC adopted new production guidelines to be in effect through July 1990.' Seven OPEC members agreed to adhere to their first half quotas (Ecuador, Gabon, Kuwait, Libya, Nigeria, Saudi Arabia, and Venezuela). Five members agreed to production limits slightly below their first half quotas (Algeria, Indonesia, Iran, Iraq, and Qatar). The U.A.E. agreed to cut production 
Flgure 1. World Average Dally Crude Oll Production Including Lease Condensate (18t Qtr 1960 - 2nd Qtr 1990)

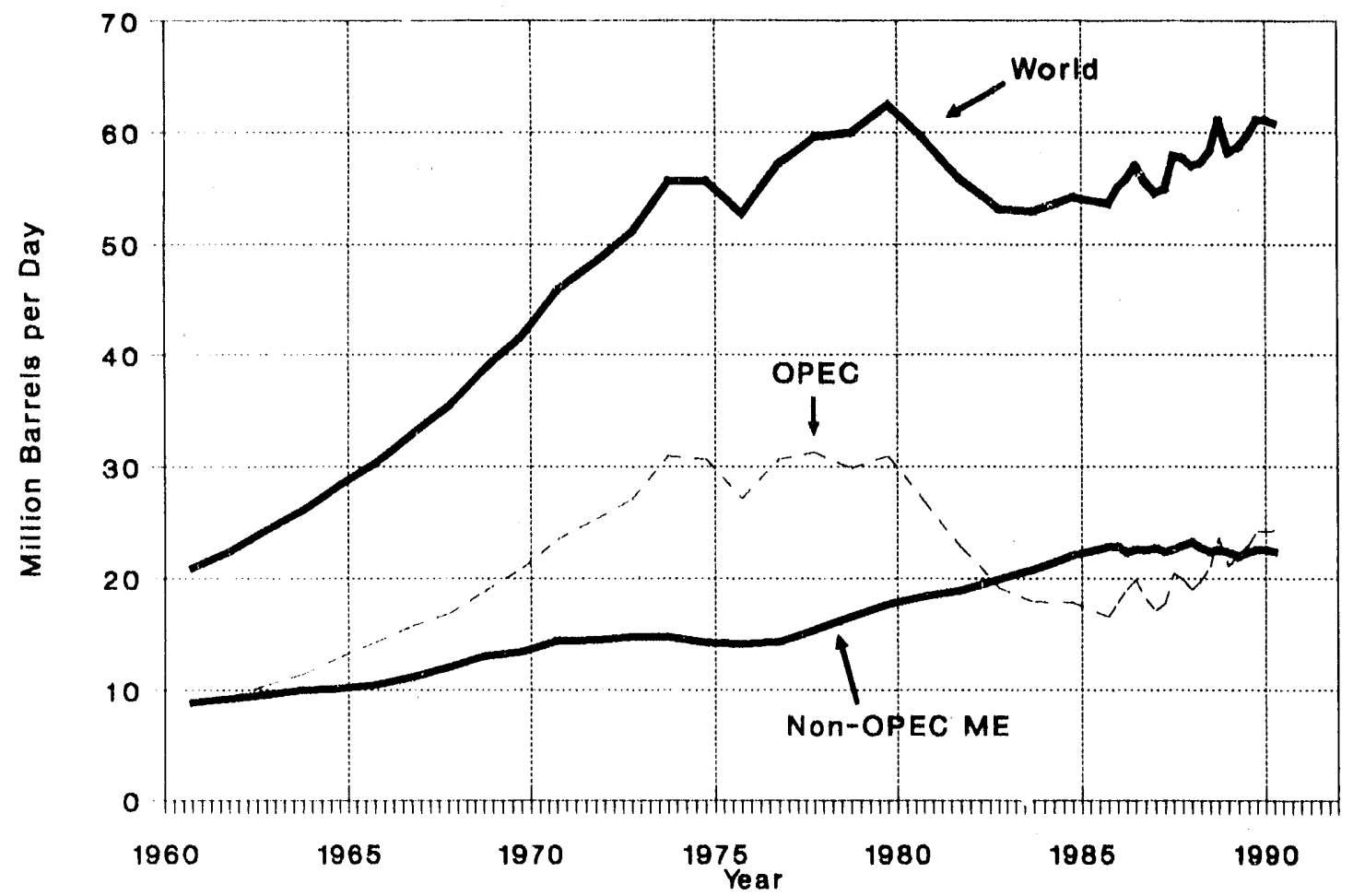

Note: Data prior to 1986 are annual averagea.

Sources: Table 2 and EIA Annual Energy Revluw 1888.

to 1.9 million barrels of crude oil per day, still well above its first half quota. Strict adherence to the new production limits should limit total (OPEC crude oil production to 22.6 million barrels per day for May, June, and July 1990. The OPEC crude oil production quota for the second half of 1990 will be 22.491 million barrels per day. Individual quotas will be the same as first half quotas except for the U.A.E. The U.A.E. quota will increase from 1.1 to 1.5 million barrels of crude oil per day.

Norway reduced its production curtailment from 7.5 to 5 percent of capacity for the first half of 1990 and may completely eliminate it in the second half of 1990. Eliminating the production curtailment could add 90,000 barrels of oil per day to Norwegian production in the second half of $1990 .^{2}$

\section{Active Rotary Drilling Rigs and World Oil Prices}

The total number of active rigs in the ME countries increased by 9 percent from the second quarter 1987 to the second quarter 1990) (Tathle 3). Rig counts have declined by 50) percent or more since the second quarter 1989 in: Ecuador, Peru, Greece, Spain, Kuwait, Kenya, and New Zealand. Countries where rig counts have declined by 50 percent or more since the second quarter 1987 are: Brazil, Peru, Austria, Greece, Spain, Kuwait, North Yemen, New Zealand, and Taiwan. Compared to the second quarter 1989, (Oman. Papua New Guinea, and Congo were able to at least double their rig counts. Denmark, the Netherlands, Iraty. Saudi Arabia, Gabon, Papua New Guinea, and the Philippines have at least doubled their rig counts compared to the second quarter 1987. 
Table 3. Quarterly Active Rotary Rigs for the Market Economies

\begin{tabular}{|c|c|c|c|c|c|c|c|c|c|c|c|c|c|}
\hline \multirow[b]{2}{*}{ Region/Country } & \multicolumn{3}{|c|}{1987} & \multicolumn{4}{|c|}{1988} & \multicolumn{4}{|c|}{1989} & \multicolumn{2}{|c|}{1990} \\
\hline & 2nd & $3 r d$ & 4 th & ist & 2nd & $3 r d$ & 4th & $1 s t$ & 2nd & $3 r d$ & $4 \mathrm{th}$ & $1 \mathrm{st}$ & 2nd \\
\hline \multicolumn{14}{|l|}{ North America } \\
\hline Canada & 81 & 196 & 248 & 271 & 146 & 206 & 158 & 177 & 90 & 103 & 148 & 197 & 78 \\
\hline Mexico & 137 & 145 & 154 & 156 & 156 & 155 & 152 & 146 & 91 & 89 & 88 & 87 & 87 \\
\hline United States & 768 & 1,001 & 1.146 & 1,002 & 902 & 923 & 922 & 786 & 773 & 890 & 1,030 & 939 & 965 \\
\hline Total & 986 & 1,342 & 1,549 & 1,429 & 1,204 & 1,284 & 1,232 & 1,108 & 954 & 1,083 & 1,265 & 1,223 & 1,130 \\
\hline \multicolumn{14}{|l|}{ South America } \\
\hline Argentina & 62 & 67 & 64 & 69 & 64 & 61 & 59 & 56 & 55 & 53 & 54 & 63 & 73 \\
\hline Bollvia & 6 & 6 & 6 & 6 & 5 & 5 & 6 & 6 & 6 & 5 & 5 & 5 & 5 \\
\hline Brazil & 62 & 55 & 53 & 42 & 43 & 32 & 39 & 35 & 34 & 22 & 20 & 22 & 24 \\
\hline Chile & 7 & 7 & 6 & 6 & 5 & 5 & 5 & 4 & 4 & 5 & 6 & 6 & 6 \\
\hline Colombia & 13 & 13 & 16 & 16 & 21 & 20 & 17 & 16 & 17 & 15 & 13 & 11 & 9 \\
\hline Costa Rica & 0 & 1 & 1 & 1 & 0 & 0 & 0 & 0 & 0 & 0 & 0 & 0 & 0 \\
\hline Ecuador & 2 & 4 & 5 & 5 & 5 & 5 & 7 & 7 & 5 & 5 & 4 & 2 & 2 \\
\hline Peru & 18 & 12 & 12 & 10 & 11 & 11 & 11 & 10 & 10 & 9 & 9 & 6 & 5 \\
\hline Trinidad & 9 & 7 & 8 & 8 & 8 & 7 & 6 & 6 & 6 & 6 & 7 & 9 & 8 \\
\hline Venezuela & 17 & 18 & 21 & 23 & 23 & 27 & 28 & 28 & 27 & 28 & 29 & 29 & 29 \\
\hline Other & 0 & 1 & 1 & 1 & 0 & 0 & 0 & 1 & 0 & 0 & 0 & 0 & 0 \\
\hline Total & 196 & 191 & 193 & 186 & 184 & 173 & 178 & 168 & 164 & 148 & 146 & 153 & 162 \\
\hline \multicolumn{14}{|l|}{ Western Europe } \\
\hline Austria & 4 & 3 & 4 & 5 & 5 & 5 & 3 & 3 & 2 & 2 & 1 & 2 & 2 \\
\hline Denmark & 1 & 4 & 5 & 3 & 1 & 2 & 2 & 2 & 3 & 2 & 1 & 2 & 2 \\
\hline France & 6 & 8 & 12 & 9 & 8 & 8 & 9 & 4 & 8 & 9 & 7 & 8 & 7 \\
\hline Greece & 1 & 2 & 2 & 2 & 2 & 2 & 2 & 2 & 2 & 0 & 0 & 0 & 0 \\
\hline Netherlands & 8 & 10 & 11 & 14 & 13 & 17 & 10 & 9 & 10 & 14 & 16 & 17 & 16 \\
\hline Italy & 25 & 26 & 25 & 23 & 23 & 24 & 26 & 28 & 25 & 19 & 17 & 20 & 20 \\
\hline Norway & 12 & 12 & 16 & 15 & 16 & 15 & 14 & 11 & 13 & 13 & 13 & 10 & 12 \\
\hline Spain & 3 & 2 & 2 & 2 & 2 & 2 & 3 & 3 & 3 & 4 & 1 & 2 & 1 \\
\hline United Kingdom & 36 & 45 & 61 & 64 & 57 & 56 & 50 & 51 & 50 & 42 & 43 & 47 & 47 \\
\hline West Germany & 9 & 12 & 16 & 12 & 10 & 10 & 5 & 7 & 8 & 9 & 9 & $\theta$ & 11 \\
\hline Other & 2 & 0 & 0 & 0 & 2 & 1 & 0 & 0 & 1 & 0 & 0 & 0 & 0 \\
\hline Total & 108 & 125 & 154 & 148 & 140 & 141 & 124 & 12.0 & 124 & 114 & 109 & 116 & 118 \\
\hline \multicolumn{14}{|l|}{ Middle East } \\
\hline Abu Dhabi & 10 & 8 & 7 & 7 & 7 & 7 & 8 & 7 & 5 & 6 & 7 & 7 & 9 \\
\hline Dubai & 2 & 1 & 2 & 3 & 4 & 3 & 4 & 3 & 2 & 3 & 2 & 3 & 3 \\
\hline Iran & 15 & 20 & 19 & 18 & 18 & 18 & 18 & 19 & 18 & 18 & 25 & 20 & 20 \\
\hline Iraq & 7 & 10 & 17 & 21 & 23 & 22 & 24 & 25 & 27 & 25 & 23 & 31 & 38 \\
\hline Jordan & 2 & 2 & 3 & 3 & 2 & 2 & 2 & 3 & 3 & 3 & 3 & 2 & 2 \\
\hline Kuwait & 6 & 6 & 6 & 5 & 6 & 6 & 5 & 5 & 4 & 3 & 4 & 3 & 1 \\
\hline North Yemen & 4 & 4 & 5 & 4 & 3 & 3 & 3 & 2 & 2 & 1 & 3 & 3 & 2 \\
\hline Oman & 11 & 9 & 10 & 10 & 9 & 8 & 10 & 11 & 9 & 14 & 18 & 19 & 18 \\
\hline Qatar & 2 & 1 & 1 & 2 & 3 & 3 & 3 & 4 & 3 & 3 & 3 & 3 & 2 \\
\hline Saudi Arabia & 5 & 5 & 4 & 4 & 4 & 5 & 5 & 6 & 6 & 5 & . 4 & 6 & 10 \\
\hline Syria & 20 & 23 & 25 & 22 & 21 & 26 & 29 & 24 & 23 & 26 & 22 & 21 & 18 \\
\hline Turkey & 29 & 25 & 23 & 22 & 21 & 24 & 18 & 25 & 19 & 18 & 17 & 17 & 17 \\
\hline Other & 1 & 1 & 0 & 0 & 0 & 0 & 0 & 2 & 1 & 1 & 2 & 2 & 1 \\
\hline Total & 114 & 114 & 120 & 122 & 122 & 126 & 129 & 136 & 122 & 126 & 134 & 136 & 142 \\
\hline
\end{tabular}

See footnotes at end of table 
Table 3. Quarterly Active Rotary Rigs for the Market Economies (Continued)

\begin{tabular}{|c|c|c|c|c|c|c|c|c|c|c|c|c|c|}
\hline \multirow[b]{2}{*}{ Reglon/Country } & \multicolumn{3}{|c|}{1987} & \multicolumn{4}{|c|}{1988} & \multicolumn{4}{|c|}{1989} & \multicolumn{2}{|c|}{1990} \\
\hline & 2nd & $3 r d$ & 4 th & $1 \mathrm{st}$ & 2nd & 3rd & 4th & $1 \mathrm{st}$ & 2nd & $3 r d$ & $4 t h$ & $19 t$ & 2nd \\
\hline \multicolumn{14}{|l|}{ Africa } \\
\hline Algeria & 46 & 39 & 34 & 34 & 33 & 33 & 28 & 19 & 19 & 25 & 33 & 35 & 37 \\
\hline Angola & 9 & 10 & 10 & 9 & 13 & 10 & 10 & 9 & 8 & 8 & $\theta$ & 8 & 8 \\
\hline Congo & 3 & 3 & 2 & 2 & 2 & 2 & 2 & 1 & 0 & 0 & 3 & 1 & 3 \\
\hline Egypt & 26 & 21 & 19 & 22 & 22 & 19 & 21 & 20 & 19 & 19 & 15 & 17 & 17 \\
\hline Gabon & 2 & 4 & 4 & 3 & 3 & 7 & 8 & 8 & 5 & 6 & 5 & 6 & 5 \\
\hline Kenya & 0 & 0 & 1 & 2 & 1 & 0 & 1 & 3 & 2 & 2 & 3 & 2 & 0 \\
\hline Libya & 11 & 13 & 15 & 16 & 17 & 15 & 17 & 19 & 18 & 16 & 15 & 15 & 15 \\
\hline Nigeria & 12 & 9 & 11 & 10 & 12 & 14 & 16 & 14 & 15 & 14 & 13 & 16 & 17 \\
\hline South Atrica & 3 & 3 & 4 & 5 & 5 & 4 & 3 & 3 & 3 & 3 & 3 & 3 & 3 \\
\hline Tunisia & 3 & 5 & 4 & 2 & 5 & 3 & 3 & 5 & 3 & 3 & 2 & 3 & 3 \\
\hline Other & 4 & 6 & 4 & 4 & 7 & 5 & 5 & 5 & 4 & 3 & 3 & 3 & 2 \\
\hline Tolal & 119 & 114 & 108 & 108 & 120 & 113 & 113 & 107 & 96 & 98 & 102 & 109 & 110 \\
\hline \multicolumn{14}{|l|}{ Asia-Pacific } \\
\hline Australia & 12 & 21 & 20 & 13 & 14 & 22 & 26 & 15 & 13 & 15 & 14 & 14 & 12 \\
\hline Bangladesh & 6 & 4 & 2 & 2 & 2 & 3 & 3 & 5 & 5 & 5 & 5 & 5 & 5 \\
\hline Brunei & 3 & 3 & 3 & 3 & 4 & 4 & 4 & 5 & 4 & 4 & 4 & 4 & 4 \\
\hline Burma & 32 & 28 & 26 & 26 & 26 & 26 & 24 & 24 & 24 & 24 & 20 & 18 & 19 \\
\hline India & 118 & 119 & 121 & 131 & 128 & 130 & 134 & 135 & 135 & 133 & 139 & 137 & 138 \\
\hline Indonesia & 38 & 31 & 36 & 43 & 42 & 46 & 45 & 45 & 46 & 46 & 47 & 50 & 52 \\
\hline Japan & 7 & 14 & 12 & 11 & 9 & 11 & 11 & 6 & 4 & 6 & 6 & 7 & 7 \\
\hline Malaysite & 9 & 9 & 9 & 8 & 8 & 9 & 10 & 11 & 11 & 11 & 13 & 14 & 15 \\
\hline New Zealand & 4 & 1 & 3 & 3 & 2 & 2 & 2 & 3 & 2 & 1 & 1 & 0 & 0 \\
\hline Pakistan & 15 & 14 & 12 & 12 & 13 & 14 & 14 & 13 & 15 & 13 & 12 & 13 & 9 \\
\hline Papua New Guinea & 2 & 2 & 2 & 2 & 3 & 2 & 4 & 3 & 2 & 3 & 4 & 4 & 4 \\
\hline Ph'ippines & 1 & 1 & 4 & 4 & 3 & 3 & 3 & 5 & 6 & 7 & 7 & 6 & 5 \\
\hline Taiwan & 6 & 3 & 4 & 4 & 5 & 4 & 4 & 5 & 5 & 4 & 5 & 5 & 3 \\
\hline Thailand & 5 & 7 & 7 & 6 & 5 & 5 & 6 & 7 & 5 & 5 & 6 & 5 & $\theta$ \\
\hline Other & 0 & 0 & 1 & 0 & 1 & 1 & 1 & 1 & 1 & 0 & 1 & 1 & 1 \\
\hline Total & 258 & 257 & 261 & 267 & 265 & 285 & 291 & 282 & 278 & 278 & 284 & 283 & 280 \\
\hline Total OPEC' & 176 & 170 & 181 & 194 & 201 & 211 & 215 & 210 & 201 & 203 & 217 & 228 & 242 \\
\hline Total Non-OPEC ME & 1.604 & 1.973 & 2,204 & 2,065 & 1,833 & 1,911 & 1,852 & 1,711 & 1,537 & 1,044 & 1,823 & 1,791 & 1,701 \\
\hline NON-OPEC ME WO U.S. & 836 & 973 & 1,058 & 1,063 & 932 & 988 & 930 & 925 & 764 & 754 & 793 & 852 & 736 \\
\hline Total ME wo U.S. & 1,011 & 1,142 & 1,239 & 1,257 & 1,133 & 1,199 & 1,145 & 1,134 & 965 & 956 & 1,010 & 1,080 & 978 \\
\hline Total MF & 1.780 & 2,143 & 2,385 & 2,259 & 2,034 & 2,122 & 2,067 & 1,920 & 1,738 & 1,847 & 2,040 & 2,019 & 1,943 \\
\hline
\end{tabular}

'Includes Middle East Other.

Note Fontary rigs are average for each quarter. A listing of OPEC, CPE, and ME countries is contained in the Glossary. ME denotes Market Economies, Column totals mily not add due to independent rounding.

Source Batker Hughes Inc. Ind Oil and Gas Journal Energy Database 
A sharp drop in rig counts occurred in 1986 (Figure 2). The drop correlates with the oil price collapse of 1986, and the rig counts have remained below pre-1986 levels. Due to its large number of drilling rigs, the United States is not included in the Non-OPEC ME and Total ME curves because it would mask the trends for these countries. Compared to 1 year ago, rig counts are 20.4 percent higher for OPEC, 3.7 percent lower for Non-OPEC ME excluding the United States, and 1.3 percent higher for the ME excluding the United States. Compared to 3 years ago, rig counts are 37.5 percent higher for OPEC, 12.0 percent lower for Non-OPEC ME excluding the United States, and 3.3 percent lower for the ME excluding the United States.

Figure 2. Quarterly Active Rotary Rigs for the Market Economles (ME)

(18t Qtr 1960 - 2nd Qtr 1990)

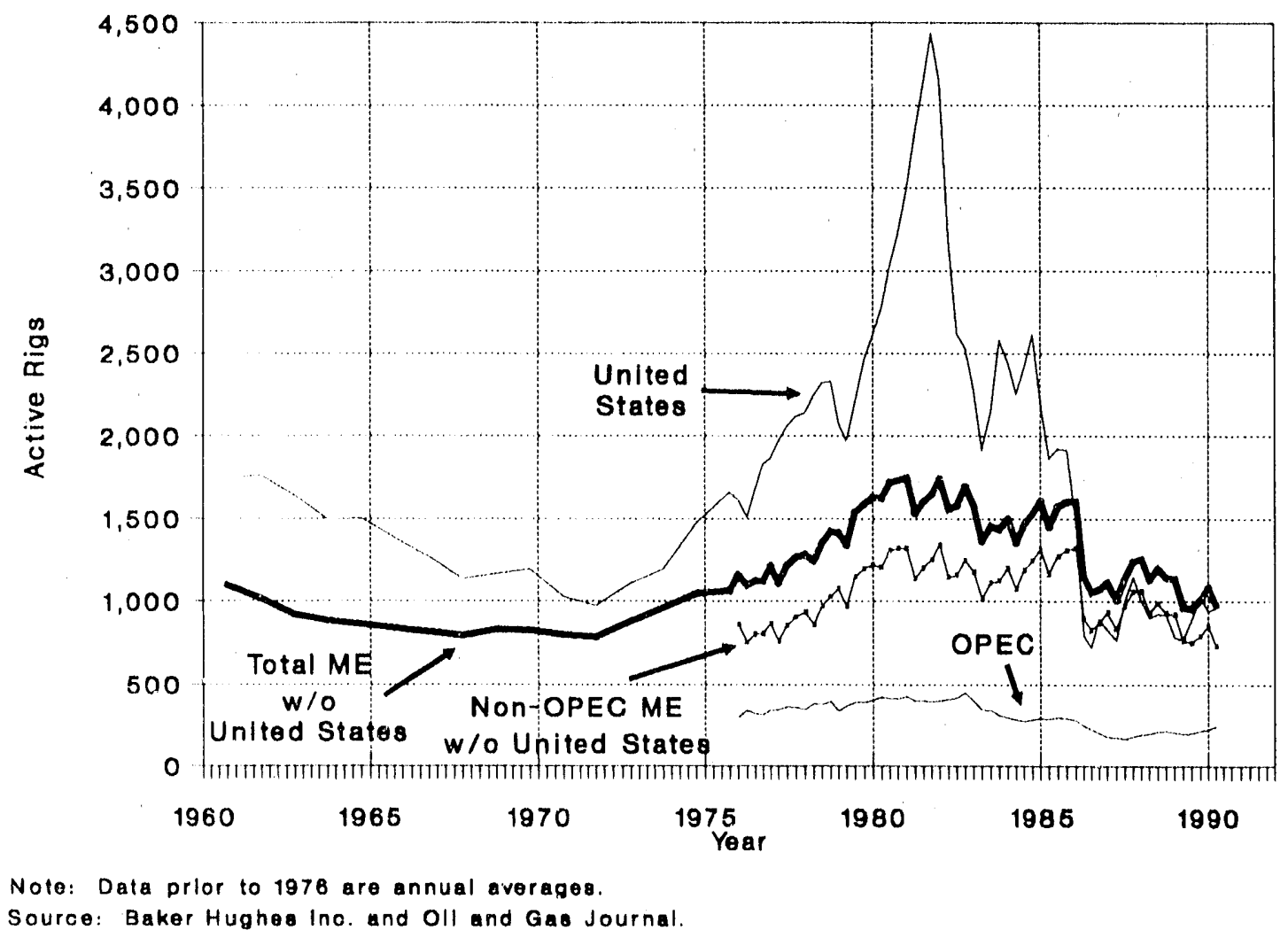

The price of imported crude oil paid by U.S. refiners reflects the trends in world oil prices (Figure 3 ). Three sharp changes in historical oil prices coincide with three events in the Persian Gulf. In 1973, oil prices increased due to the Arab oil embargo. Oil prices increased again in 1979 due to the Iranian revolution and the start of the Iran-Iraq war. Then in 1986, OPEC increased production beyond demand and oil prices collapsed.

\section{Highlights}

Selected items taken from industry trade joumals considered to be important to future supplies of oil and gas are discussed briefly. Although significant, some activities and their expected results may be highly speculative. Reserve figures mentioned here that are considered to be unrealistic are not included in tata or calculations contained elsewhere in this report. Conversely, reserve estimates considered to be realistic are included in the tables and appendices of this report. 
Figure 3. U.S. Refiner Acquisition Cost of Imported Crude OII (1st Qtr 1968 - 2nd Qtr 1990)

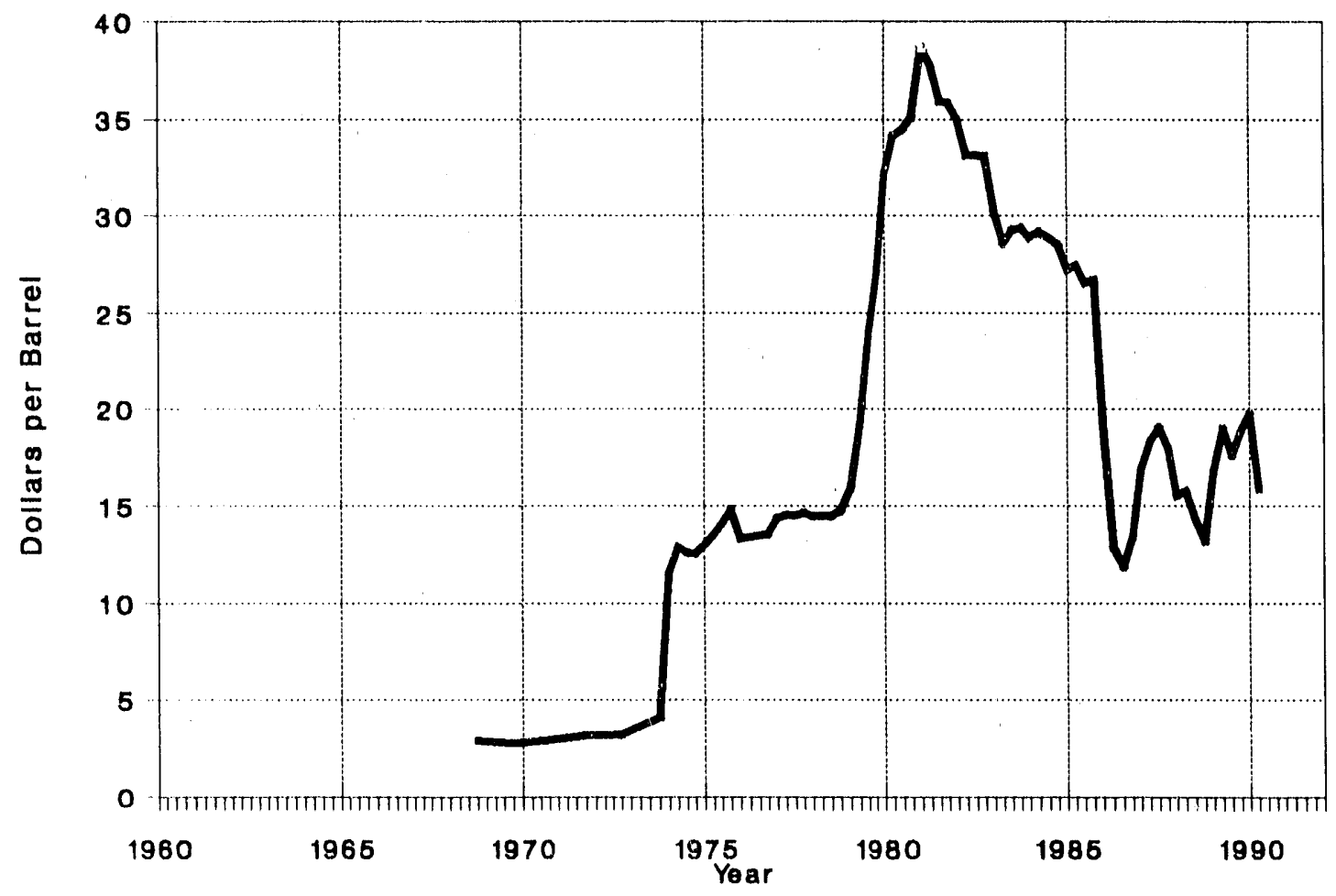

Note: Data prlor to 1974 are annual averages.

Source: 1968-1986, ElA Annual Energy Reviow 1989;

1987-1890, ElA Weekly Petroleum Status Report 8/10/80.

Countries in the Middle East are beginning production capacity expansion programs in anticipation of increasing world demand for their oil. ${ }^{3}$ Saudi Arabia plans an increase to 10 million barrels of oil per day (close to peak Saudi production achieved in 1980-81) by the year $2(x) 0{ }^{4}$ Included in the Saudi program is a $\$ 1.7$-billion project to increase capacity of the east-west crude oil pipeline to Yanbu from 3.2 to 5 million barrels per day. This involves expansion of the 11 pump stations along the line as well as the export facilities on the Red Sea. For large gas oil separation plants for the offshore Safaniya field are planned at a cost of $\$ 400$ million for a gain of 270,000 barrels per day. Also planned is a $\$ 120$-million expenditure for two gas oil separation plants in Uthmaniyah field to increase productior. to 300,000 barrels per day. Development of the remote Shaybith field, located close to the borders of the U.A.E. and Oman, should be completed by 2003 at a cost of $\$ 2.96$ billion. Productive capaciry of the field will be 500,000 batrels of oil per day. Saudi Arabia and other Middle East countries are starting to reactivate production facilities that have been mothballed for 6 to 7 years.

Iraq's current productive capacity is 4.5 million barrels of oil per day, and according to Iraq's Oil Minister, another 1.5 to 2 million harrels per day will be added through the exploitation of proved undeveloped reserves. ${ }^{3}$ Suba field has added $60,()(0)$ barrels per day this year, and Khabbaz and Saddam fielss are expected to add a combined 80,000 barrels per day later in the year. Work in the Zuhair field should increase production from 70,000 to 230,000 barrels per day. Development of West Qurna field is expected to add 200,000 barrels per day this year and another 400,000 barrels per day before the end of the decade. Iraq's oil export capacity is just under 4 million barrels per day. Capacity of the pipeline through Saudi Arabia to Muajijiz on the Red Sea is 1.65 million barrels per day with 10 million barrels of storage on the coast. Iray's pipeline capacity to the Mediterranean through Turkey is 1.5 million barrels per day and the Mina al-Bakr terminal on the Persian Gulf has 
an export capacity of 800,000 barrels per day. Plans are being made to expand export capacity at Mina al-Bakr to the prewar (Iran-Iraq war) level of 1.6 million barrels per day and to repair the Khor al-Amaya offshore facility.

Oman plans to increase oil production this year to 700,000 barrels per day from 640,000 barrels per day in $1989 .{ }^{3}$ Two-thirds of the net increase will be from the development of 25 to 30 fields. Oman's Oil Minister said Oman found 300 million barrels of oil reserves in 989 and now has remaining reserves of 4.3 billion barrels of oil.

Abu Dhabi has a $\$ 5(1)$-million program to increase onshore oil productive capacity by 360,000 to 1.125 million barrels per day by 1995." Already underway is a program to increase offshore oil productive capacity by 200,000 to 1 million barrels per day. Asab lield capacity should increase from 60,000 to 280,000 barrels per day. Infill drilling in Bab field should increase production by $17(0,0)(0)$ to 210,000 barrels per day by 1995. In Bu Hasa field, water injection will be upgraded to increase capacity by 100,000$)$ to 550,000 barrels per day. Shah and Sahil fields are expected to add a combined 15,000 to a total of $45,000)$ barrels per day.

Kuwait signed an exploration agreement with the Soviet Union allowing their oil companies to operate in the other's country. ${ }^{6}$ Kuwait can now explore for oil in the Turkmenian Republic of the U.S.S.R. The Soviet's Technoexport is working on a $\$(6)$-million project for Kuwait Oil Co. for desalting and dehydration. ${ }^{7}$ This work was previously done by U.S. ar ${ }^{4}$ Japanese firms. The Soviets are also considering developing Bahrah oil field in northern Kuwait.

After an 11 year suspension, Iran has resumed gas exports to the Soviet Union from its southern gas fields. ${ }^{8}$ The 15 -year contract is for sales of 94 billion cubic feet per year, but could climb to 313 billion cubic feet per year.

The two countries of North and South Yemen merged into the Republic of Yemen on May 22, $1990 .{ }^{9}$ The govemment reported estinuted reserves for the new country of 4.75 billion barrels of oil, 3.75 billion in the south and 1 billion in the north."

Nigeria may increase drilling this year by 30 percent to 155 wells." Shell, Nigeria's busiest operator, is planning 94 wells. Shell added more than 700 million barrels of oil to Nigeria's reserves in the last 4 years. ${ }^{12}$ During the next 4 years, Nigeria plans to add 6 billion harrels of oil reserves from 16 to 22 billion barrels. Also planned is a production increase from 1.85 to 2.4 million barrels per day.

Enhanced oil recovery is expected to add 21 billion barrels of oil to Libya's reserves according to Libya's Oil Minister. ${ }^{13}$ He said, of Lihya's 180 billion barrel resource, only 45 billion barrels are recoverable by primary and secondary means (without enhanced recovery methods).

The main proxlucing nations of West Africa contain at least 359 undeveloped oil and gas discoveries. ${ }^{14}$ Nigeria has the largest number, but half of the fields are in Angola, Gabon, Congo, and Cameroon. Two-thirds of the fields are offshore in easily accessible coastal waters, and three-fourths of the undevelopeci discoveries are oil fields.

The U.S.S.R.'s Tengiz field may be added to a proposed joint venture between Chevron and the Soviet Union. ${ }^{15}$ Recoverable reserves in Tengiz. are currently estimated at 10 to 11 billion barrels of oil from 25 billion barrels in place. Some estimates of in-place resources are as high as 40 billion barrels of oil and 46 trillion cubic feet of gas. Tengiz production is highly corrosive and must be processed through an oil and gas processing plant which is currently under construction. When finished, the plant will have expected production of 180,000 barrels per day of oil, 230 million cubic feet per day of dry gas, and 3,700 metric tons per diay of sulfur. The Soviet Union exported 21 percent of its oil production and 12.7 percent of its gas production in 1989. ${ }^{16}$ ()il and refined product exports for 1989 were 3.694 million barrels per day, down from 4.104 million harrels per dily in 1988. (ias exports, however, increased in 1989 to about 3.57 trillion cubic feet compared to 3.07 trillion cubic feet in 1988. The increased gas sales did not offset the loss of revenue from the lower oil and product sales.

The Inited Kingdom's oil production is expected to drop by, 300,000 barrels per day this summer. ${ }^{17}$ The drop is due to the installation and relocation of emergency shutdown valves on offshore platforms which requires the platforms to be shutdown 10 perform the work. The installation must be completed by the end of the year. There are 57 oil and gas fields in the II.K. North Sea waiting to be developed that could be approved in the next 2 to 3 years. ${ }^{18}$ The 57 projects have combined reserves of 3.8 billion barrels of oil and 14.4 trillion cubic feet of gas. Liquid production from the group may peak 
in 1996 at 1.2 million barrels per day, about half of total U.K. production in that year. Gas production is expected to peak later at 3.1 billion cubic feet per day. Of the 57 fields, 31 are in the central North Sea, 14 in the northern North Sea, 11 in the southem gas province, and 1 in the Irish Sea.

Norway has announced the results of its 1990 report that doubles the estimate of Norwegian North Sea undiscovered oil and gas resources compared to a 1989 report. ${ }^{19}$ Resources that are still to be found are now estimated at 5.9 billion barrels of oil and 31.95 trillion cubic feet of gas.

Permission has been granted to develop the Ballycotton gas field off Ireland in the Celtic Sea. ${ }^{20}$ The small gas field will be the second operating offshore field and the first subsea development in Irish waters. The field is expected to extend Irish reserves about one year.

The Duri field steamflood project in Indonesia has added 2 billion barrels of oil to the country's reserves. ${ }^{21}$ Current oil production from Duri field is 160,000 barrels per day. Peak proluction of 330,000 barrels per day should be reached in the mid-1990's and will begin declining in the next decade. There is another 1 billion barrels of tertiary oil potentially recoverable from other reservoirs in the field. Also, a change from a peripheral waterflood to a pattem waterflood in the Minas field is expected to increase recovery by 500 milhon barre. Exploratory drilling is on the rise from 82 wells in 1987 to an expected 120 wells in 1990) to a projected peak of 190 in 195. "Indonesiar vil production is expected to increase through 1991 and then decline to less than 1.3 million barrels per day in 1998 when the country will become a net importer of oil.

Oil India Lid. of India has requested approval to develop the Disang oit shales in the northeast. ${ }^{23}$ Tire 3,860 square mile area is estimated tn contain a resource of 438 billion barrels of oil equivalent.

Brazil estimates the developmer: .ost of the deep water Albacora and Marlim fields at $\$ 10$ billion over the next 10 years. ${ }^{24}$ For the Marlim field, the plan includes a tension leg platform in 3,280 feet of water with a production capacity of 100,000 barrels of oil per day.

Argentina announced an oil policy that will enable foreign companies to purchase nroduction rights in and operate major fields. ${ }^{25}$ The foreign contractors can dispose of their share of production or sell it to the Argentina state oil company at world oil prices.

\section{Data Sources and Analysis}

There are three main sources of information used in this report: 1) Petroconsultants, S.A, 2) industry tmde journals, and 3) the Energy Information Administration (EIA) (Figure 4).

The quarterly production in Table 2 is a summary of the monthly data presented in the ElA Monthly Energy Review. The average quarterly drilling rig counts of Table 3 are derived from Baker Hughes' data published monthly and weekly in industry trade joumals. Also, remaining reserves by country shown in Appendix C, "World Oil and Natural Gas Reserves," are taken directly from industry trade journals. Subtotals at the ends of Table 3 and Appendix $C$ are added for the readers' comvenience

Petroconsultants provides an updated data base each quarter containing field level estimates of ultimate recovery. Field ultimate recovery estimates are summed to the country level and then compared to country totals of previous editions of the datla hase 10 get the changes in ultimate recovery over time. These changes are the reserve additions shown in Appendix B, "Mordified Petroconsultants Reserve Additions." for the last 3 months, 12 months, and 36 months. For example, reserve additions for the last 12 months are calculated by subtracting the ultimate recovery values of the second quarter 1989 from the ultimate recovery values of the second quart : 1990 . The reserve additions for any given time period are the latest ultimate recovery estimates in that lime period minus the ultimate recovery estimates prior to that time perickl. The modification of Petroconsultants data nccurs when a field which has a reserve history in Appendix A, appears for the first time in the Petroconsultants data hase. The reserve history of the field from Appendix $A$ is then eritered into the pre. us editions of the Petroconsultants ditat to smooth the transition from one source to another. (Petriconsultants is the primary source for reserve additions in this report.

Energy Information Administration Internallonal Oil \& Gas

Exploration \& Development Activities Second Quarter 1990 
Flgure 4. Data Sources and Flow

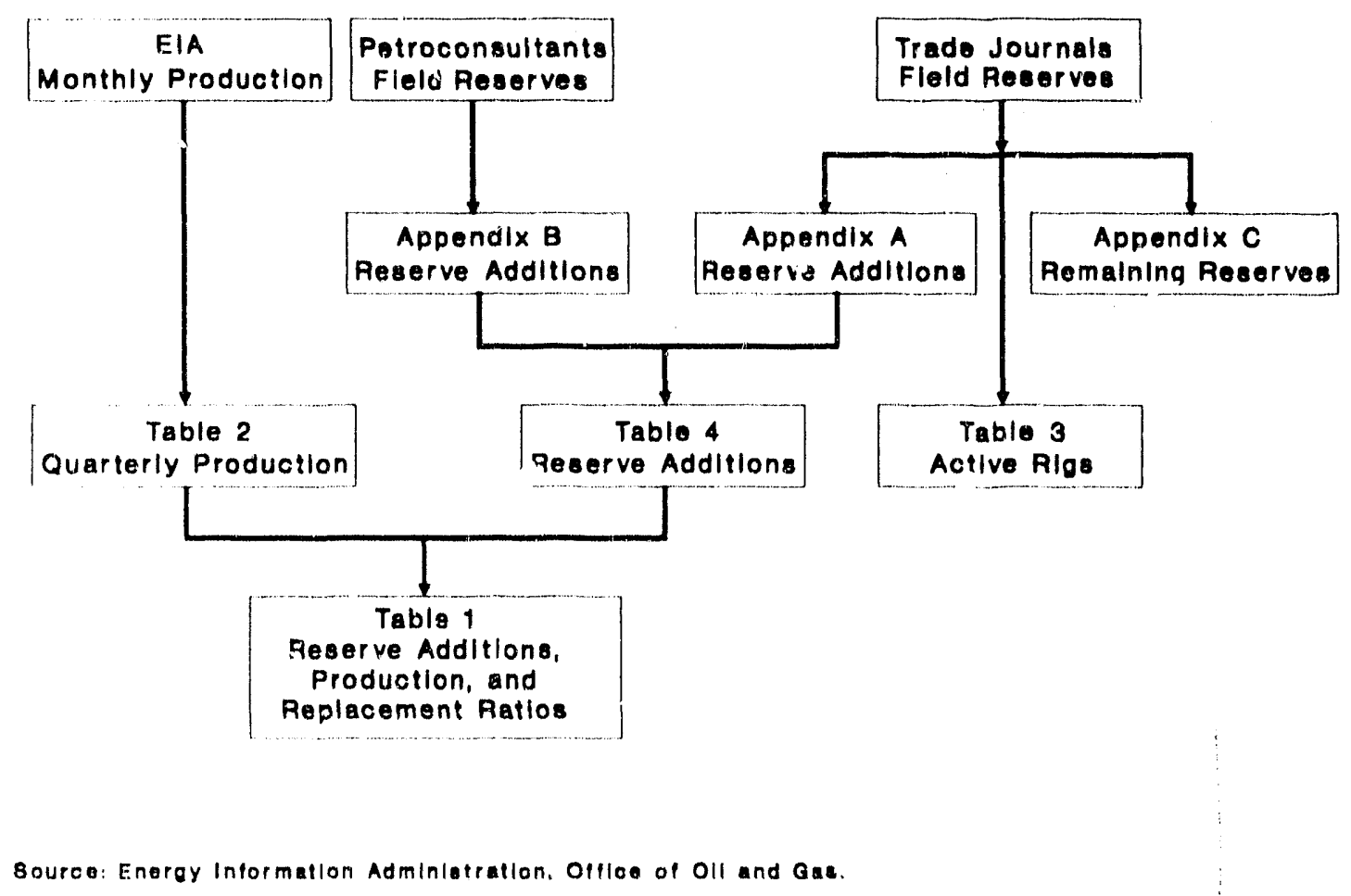

It is impractical for Petroconsultants to include every field for every country in its data base. Reserve additions calculated for a particular country from Petroconsultants data may not include reserve revisions for every field in that country. In fact, Petroconsultants does not include the United States and Canada in its data base because of the large number of fields in these two countries. Also, not every country is updated every quarter. Several years may elapse between updates for some countries. The result is that these countries may show larger reserve revisions occasionally rather than smaller more frequent reserve revisions. It should he kept in mind when drawing conclusions from the data presented in this repoit that a large change in reserves reported in a given quarter for a country could represent changes that actually occurred over several years.

Petroconsultants second quarter 1990 data contain 11,061 field entries, 1,732 more entries than in the second quarter 1987 data. Most of the reserve additions are from revisions to old fields and not from the 1,732 new entries. Many of the new eritries are for fields discovered before the second quarter 1987 and some may have been discovered 15 or 20 years ago (that is, the discovery well was drilled 15 or 20 years ago). In rost areas of the world, a field is not considered as having reserves until it is feasible to develop. A field may become feasible for development mi.ny years after discovery due to changes in economics. technology, infrastructure, etc. The Petroconsultants data base has two categories for its reserves, fields and discoveries. A field is defined as having commercial production or a firm commitment to develop it for production. Petroconsultints de fines a discovery as having no commercial production or commitment to develop, but has tested substantial quantities of oil and gats as determined by local economics. The reserves of both discoveries and fields are used in this report (both fields and discoveries are referred to as fields)

Reports of field reserves published in industry trade joumals ard some company annual or quarterly reports are listed in Appendix A. "Fonign ()il and (Gas Discoveries." The data are organized by country and field with the new entries shaded. The more significant new entries are discussed briefly and located on maps in the "Reserve Additions" section of this report. 
Unlike Petroconsultants data, the entries in Appendix A are not simply replaced when new data become available. Updates of a field's reserves are added to the appendix and do not replace previous entries so it is possible to note reserve estimate changes over time. Also, reservo ranges, when available, are entered to give the reader a sense of the field': additional porential.

Reserve additions for a field in Appendix A for any time period are the latest ultimate recuvery estimate in the time period minus the latest ultimate recovery estimate prior to the time period. For example, a new field first reported in July 1987 with it 20(1-million-barrel ullimate recovery estimate, an upward revision to 400 million barrels reported in July 1989, and a further upward revision to 600 million barrels in April 1990, would yield reserve additions of 200 million barrels in the last 3 months, 400 million harrels in the last 12 months, and 600 million barrels of $c_{i 1}$ in the last 36 months. Fields in Aprendix A marked with an asterisk $\left(^{*}\right.$ ) are also present in the Petroconsultants data base. Reserve additions for fields not marked with an asterisk were added to the reserve additions of Apnendix B, along with U.S. and Canadian reserve additions, to form Table 4, "World Oil and Gas Reserve Additions."

The path io 'Tahic 4, illustrated in Figure 4, has been from Petroconsultants field level reserves io Appendix B's reserve additions and from published field reserves in trade joumals to Appendi: $A$. Reserve anditions from fields in Appendix $A$ which are no: in Appendix B (no asterisk) were added to Appendix B along with U.S. and Canadian reserve additions to form Table 4 . Table 4 lists the oil and gas reserve additions for the last 3 months, last 12 months, and last 36 months by country through June 1990. For the last 12 months, oil reserve additions for the world are 32.2 billion barrels of oil. OPEC's reserve additions are 8.5 billion harrels of oil, 26 percent of the world total. The Non-OPEC ME reser e additions are 9.8 billion harrels of oil. 30 fercent of the world tot al. CPE serve additions are 13.9 billion barrels of oil, 4. percent of the world total. If the Soviey I mion's Tengiz. field is excluded, than OPEC would have 30 percent of world reserve additions, Non-OPEC lade v Id have 35 percent. and the CPE would have 35 percent for the last 12 months. For the last 36 months, world reserve additions are 2.43 billion, harrels of oil. OPEC"s reserve additions are 1.54 billion barrels of oil, 63 percent of the world total. The Non-1)PF: C MFt and ( PEE reserve additions contribute about 24 ard 13 percent, respectively, to the world total. The major portion of world is reserve iddditions came from OPEC. Once again, most of these reserve additions are due to revisions for ohler ficlds. mor new discoveries. In Table 4 and Appendix B for Saudi Arabia there is a decrease in gas reserves of about 1010 trillion cuhic feet Petriconsultants has corrected an error that indicated a reserve increase of the same magnitude in the lourth yuarter 1989 report.

It is mot surprising that oPEC has most of the oil reserve additions when the remaining reserves listed in Appendix $\mathrm{C}$ are considered. OPFC has 76 percent of the world's remaining oil reserves while the Non-OPEC ME have 16 percent and the CPE have 9 percent illiwld oil figures). Based on the production rates for the last 12 months, OPEC has an 81 -year supply of cill. The Non-1)PEC' ME have an 18-year supply, and the CPE have a 16-year supply of oil. Given 75 percent of the world's remiuning oil reserves with an 81 -year supply at current production rates, (OPEC has the potential for ongoing upward reserve nevismons for many years.

Finally. the reserve andditions data of Table 4 are divided by the production data of Table 2 to yield the reserve replacement rattice of Tathe 1 . For the last 36 and 12 months the world. OPEC. Non-OPEC MF, and CPE replacement ratios are shown. The replacemerll rathos in the tahte are equal to reported reserve additions divided by production. Also shown are net reserve addulors whuch are equal to reported reserve ardditions minus the production. A replacement ratio greater than 1:1 means that gross reserve additans are greater than production. A tatio of 5.1$): 1$ would indicate that gross reserve additions are 5 times the prestucen verlume

companed to last iquarter's repont. the world replacement ratio dropped from $3.8: 1$ 10 $3.7: 1$ for the last 36 months. OPEC:

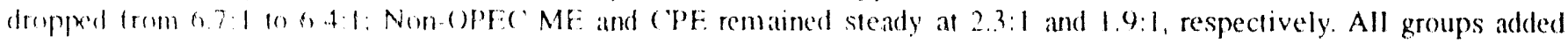
subutintrally more ull reserves than they produced in the last 3 months. For the last 12 months the world replacement ratio

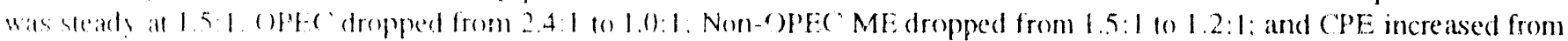

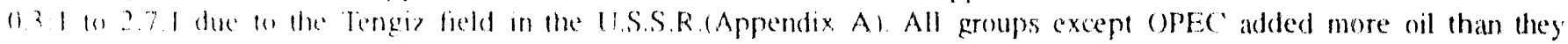
prodecied on the last 12 months: 1 )PFe' stilyed even.

The wil production wolumes losed in Tathe 1 for the last 12 months indicate that oPEC and Non-oPEC ME preduced approximately 39 and 27 percent of the world oil supply while the (PE prokluced 24 percent of the world supply. In the last

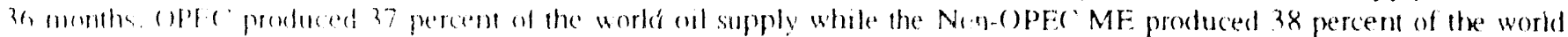


Table 4. World OII and Gas Reserve Additions

\begin{tabular}{|c|c|c|c|c|c|c|}
\hline \multirow[b]{2}{*}{ Country } & \multicolumn{3}{|c|}{ Oll, MMbbis } & \multicolumn{3}{|c|}{ Natural Gas, Bcf } \\
\hline & $\begin{array}{c}\text { Lasi } 3 \\
\text { Months } \\
4 / 90-6 / 90 \\
\end{array}$ & $\begin{array}{c}\text { Last } 12 \\
\text { Months } \\
7 / 89-6 / 90 \\
\end{array}$ & $\begin{array}{c}\text { Last } 36 \\
\text { Months } \\
i / 87-6 / 90\end{array}$ & $\begin{array}{c}\text { Last } 3 \\
\text { Months } \\
4 / 90-6 / 90 \\
\end{array}$ & $\begin{array}{c}\text { Last } 12 \\
\text { Months } \\
7 / 89 \cdot 6 / 90\end{array}$ & $\begin{array}{l}\text { Last } 36 \\
\text { Months } \\
7 / 87-6 / 90\end{array}$ \\
\hline \multicolumn{7}{|l|}{ North America } \\
\hline Canada & 190 & 199 & 1,309 & 300 & 5,790 & 9,533 \\
\hline Cuba & 0 & 59 & 60 & 0 & 139 & 139 \\
\hline Guatemala & 0 & -8 & 21 & 0 & -4 & -4 \\
\hline Mexico & 0 & 840 & 19,225 & 0 & $3 ; 899$ & 24,229 \\
\hline United States & 0 & 2,427 & 8,324 & 0 & 16,075 & 25,297 \\
\hline Total & 190 & 3,517 & 28,939 & 300 & 25,899 & 59,194 \\
\hline \multicolumn{7}{|l|}{ South America } \\
\hline Arjentina & 141 & 339 & $3,0,09$ & 410 & $-3,479$ & 25,117 \\
\hline Barbados & 0 & -2 & -3 & 0 & -3 & 8 \\
\hline Bolivia & 1 & 2 & 41 & 0 & 245 & 562 \\
\hline Brazil & 410 & 2,091 & 5,211 & 290 & 1,509 & 5,316 \\
\hline Chile & 0 & 24 & 168 & 0 & 99 & 7,274 \\
\hline Colombia & 50 & 513 & 1,285 & 1,248 & 1,700 & 2,192 \\
\hline Ecuador & 23 & 52 & 492 & 37 & 179 & -284 \\
\hline Peru & 0 & 32 & 20 & 0 & 0 & 11,636 \\
\hline Suriname & 0 & 0 & 9 & 0 & 0 & 0 \\
\hline Trinidad & 45 & 135 & 273 & 300 & 102 & 332 \\
\hline Venezuela & 196 & -146 & 21,334 & 3,242 & 5,802 & 16,352 \\
\hline Total & 866 & 3,040 & 31,839 & $5,52 i$ & 6,154 & 68,505 \\
\hline \multicolumn{7}{|l|}{ Western Europe } \\
\hline Austria & 5 & 2 & 29 & -4 & 75 & 350 \\
\hline Denmark & 32 & 76 & 357 & 123 & 241 & 118 \\
\hline France & -3 & 14 & 139 & 0 & 498 & 2,333 \\
\hline Greece & 0 & 0 & -46 & 0 & 0 & -15 \\
\hline Ireland & 1 & 1 & 11 & 2 & 302 & 349 \\
\hline Italy & -32 & -24 & 163 & 298 & 2,998 & 2,047 \\
\hline Netherlands & 10 & 4 & 156 & 1,953 & 4,1785 & 4,711 \\
\hline Norway & -219 & 1,271 & 3,592 & 660 & 5,365 & 5,465 \\
\hline Spain & 0 & -8 & 12 & 0 & -40 & -18 \\
\hline Svalbard & 0 & 0 & 0 & 500 & 500 & 500 \\
\hline Sweden & 0 & 0 & 64 & 0 & 0 & 0 \\
\hline Switzerland & 0 & 0 & 0 & 0 & 0 & 4 \\
\hline United Kingdom & -208 & 47 & 4,043 & 1,033 & 1,245 & 14,534 \\
\hline West Germany & 70 & 71 & 268 & .847 & -4 & $-1,292$ \\
\hline Total & -344 & 1,454 & 8,788 & 3,718 & 16,165 & 29,086 \\
\hline \multicolumn{7}{|l|}{ Eastern Europe } \\
\hline Bulgaria & 0 & 0 & 0 & 0 & 0 & -350 \\
\hline Poland & 0 & 0 & 0 & 0 & 25 & 27 \\
\hline Romirania & 0 & 75 & 213 & 0 & 0 & 282 \\
\hline U.S.S.R. & 1,000 & 8,735 & 19,355 & 35,000 & 303,487 & 364,847 \\
\hline Yugoslavia & 0 & 53 & 764 & 45 & 873 & 3,272 \\
\hline Total & 1,000 & 8,863 & 20,332 & 35,045 & 304,385 & 368,078 \\
\hline
\end{tabular}

See footnotes at end of table. 
Tavle 4. World Oll and Gas Reserve Additions (Continued)

\begin{tabular}{|c|c|c|c|c|c|c|}
\hline \multirow[b]{2}{*}{ Country } & \multicolumn{3}{|c|}{ OII, MMbbls } & \multicolumn{3}{|c|}{ Natural Gas, Bcf } \\
\hline & $\begin{array}{c}\text { Last } 3 \\
\text { Months } \\
4 / 90-6 / 90\end{array}$ & $\begin{array}{l}\text { Last } 12 \\
\text { Mionths } \\
7 / 89-6 / 90\end{array}$ & $\begin{array}{c}\text { Last } 36 \\
\text { Months } \\
7 / 87-6 / 90\end{array}$ & $\begin{array}{c}\text { Last } 3 \\
\text { Mor:ths } \\
4 / 90-6 / 90\end{array}$ & $\begin{array}{l}\text { Last } 12 \\
\text { Months } \\
7 / 89-6 / 90\end{array}$ & $\begin{array}{c}\text { Last } 36 \\
\text { Months } \\
7 / 87-6 / 90\end{array}$ \\
\hline \multicolumn{7}{|l|}{ Middle East } \\
\hline Abu Dhabi & 0 & 594 & 27,879 & 190 & 2,150 & 33,965 \\
\hline Bahrain & 0 & 0 & -50 & 0 & 500 & 2,000 \\
\hline Dubai & 0 & 70 & 70 & 0 & 0 & 250 \\
\hline Iran & 450 & 1,007 & 25,717 & 1,000 & 201,221 & 271,420 \\
\hline Iraq & 1,700 & 4,100 & 49,641 & 500 & 10,900 & 27,338 \\
\hline Israel & 0 & 0 & 25 & $\mathfrak{o}$ & 6 & 6 \\
\hline Jordan & 0 & -2 & -47 & 0 & 0 & 1,000 \\
\hline Kuwait' & 0 & 500 & 17,926 & 0 & 500 & 12,814 \\
\hline Oman & 0 & 921 & 2,090 & 0 & 605 & 2,934 \\
\hline Qatar & 0 & 50 & 460 & 0 & 25 & 148,535 \\
\hline Ras Al Khaimah & 0 & 0 & 0 & 0 & $-3,900$ & $-3,5 n 0$ \\
\hline Saudi Arabia' & $-3,187$ & -88 & 11,821 & $-416,146$ & $-1,646$ & 8,389 \\
\hline Sharjah & 0 & 0 & 14 & 0 & 0 & 493 \\
\hline Syria & 0 & 370 & 298 & 0 & 250 & 1,150 \\
\hline Turkey & 2 & 162 & 135 & 0 & -39 & 329 \\
\hline Umm Al Qaiwain & 0 & 0 & 0 & 0 & 0 & 250 \\
\hline Yemen & 0 & $85 \hat{3}$ & 1,303 & 0 & 7,800 & 11,300 \\
\hline Total & $-1,035$ & 8,537 & $+37,282$ & $.414,456$ & 218,360 & 221,190 \\
\hline \multicolumn{7}{|l|}{ Africa } \\
\hline Algeria & 30 & 1,057 & 966 & 3 & $-1,535$ & 24,770 \\
\hline Angola & 28 & 568 & 822 & 10 & 3,420 & 3,454 \\
\hline Benin & 0 & 3 & -80 & 0 & 0 & 0 \\
\hline Cameroon & 0 & 0 & 29 & 0 & 0 & $-1,157$ \\
\hline Chad & 10 & 15 & 94 & 0 & 0 & 0 \\
\hline Congo & 62 & 134 & 502 & 96 & 127 & -945 \\
\hline Cote D'Ivoire & 0 & 1 & -74 & 0 & -344 & 486 \\
\hline Egypt & 121 & 481 & 846 & 116 & 3,278 & 8,744 \\
\hline - Ethiopia & 0 & 0 & 0 & 0 & 0 & 850 \\
\hline Gabon & 22 & 181 & -140 & 5 & 97 & -436 \\
\hline Ghana & 0 & 0 & 5 & 0 & 1 & 2 \\
\hline Guinea Equatorial & 0 & 0 & 0 & 0 & 0 & 802 \\
\hline Libya & 1,367 & 892 & $-3,644$ & 146 & 3,318 & 4,004 \\
\hline Morocco & 0 & 0 & 10 & 0 & -9 & 28 \\
\hline Namibia & 0 & 0 & 0 & 0 & 0 & 1700 \\
\hline Nigeria & -80 & 111 & .885 & 1,137 & 13,145 & 66,655 \\
\hline Senegal & 0 & 0 & -90 & 0 & 0 & 15 \\
\hline So. Africa & 0 & 19 & 20 & 90 & 636 & 636 \\
\hline Sudan & 0 & 0 & 327 & 0 & 0 & 839 \\
\hline Tanzania & 0 & 0 & 0 & 0 & $-6,090$ & $-6,090$ \\
\hline Tunisia & -140 & -183 & -299 & 0 & -61 & $-1,048$ \\
\hline Zaire & 0 & 11 & -42 & 0 & 1 & $\begin{array}{r}-1,040 \\
2\end{array}$ \\
\hline Total & 1,420 & 3,290 & $-1,633$ & 1,603 & 15,984 & 103,311 \\
\hline
\end{tabular}

Seg footnotes at end of table. 
Table 4. World Oil and Gas Reserve Additions (Continued)

\begin{tabular}{|c|c|c|c|c|c|c|}
\hline \multirow[b]{2}{*}{ Country } & \multicolumn{3}{|c|}{ Oil, MMbbls } & \multicolumn{3}{|c|}{ Natursl Gas, Bcf } \\
\hline & $\begin{array}{c}\text { Last } 3 \\
\text { Months } \\
4 / 90-6 / 90\end{array}$ & $\begin{array}{c}\text { Last } 12 \\
\text { Months } \\
7 / 89-6 / 90\end{array}$ & $\begin{array}{c}\text { Last } 36 \\
\text { Months } \\
7 / 87-6 / 90\end{array}$ & $\begin{array}{c}\text { Last } 3 \\
\text { Months } \\
4 / 90-6 / 90\end{array}$ & $\begin{array}{c}\text { Last } 12 \\
\text { Months } \\
7 / 89-6 / 90\end{array}$ & $\begin{array}{c}\text { Last } 36 \\
\text { Months } \\
7 / 87-6 / 90\end{array}$ \\
\hline \multicolumn{7}{|l|}{ Asla-Pacific } \\
\hline Australia & -109 & 411 & 951 & 565 & 1,760 & 6,044 \\
\hline Bangladesh & 0 & 0 & 42 & 0 & 800 & 3,053 \\
\hline Brunei & 20 & 37 & 876 & 100 & -520 & 4,331 \\
\hline China & 2,109 & 4,929 & 12,683 & 2,482 & 7,486 & 14,687 \\
\hline India & -161 & 181 & 593 & 200 & -19 & 1,418 \\
\hline Indonesia & -119 & 113 & 1,946 & $-1,726$ & $-1,747$ & 66,552 \\
\hline Japan & 5 & 18 & 73 & 0 & 81 & 396 \\
\hline Málaysia & 7 & 495 & 1,077 & $-1,790$ & $-2,370$ & $-7,064$ \\
\hline Myanmar (Burma) & 1 & $-3,006$ & 81 & 0 & -538 & 1,234 \\
\hline New Zealand & 0 & 17 & 92 & 567 & 640 & 823 \\
\hline Pakistan & 14 & 119 & 256 & 178 & 2,225 & 4,785 \\
\hline Papua New Guinea & 0 & 120 & 185 & 550 & 1,030 & 4,406 \\
\hline Philippines & -1 & 5 & 39 & -70 & 605 & 331 \\
\hline So. Korea & 0 & 0 & 0 & 0 & 190 & 200 \\
\hline Taiwan & 0 & 0 & 11 & -97 & -101 & -83 \\
\hline Thailand & -1 & 7 & 10 & 167 & 419 & 4,347 \\
\hline Vietriam & -1 & 39 & $-1,905$ & -45 & -5 & 75 \\
\hline Total & 1,764 & 3,485 & 17,010 & 1,081 & 9,936 & 105,535 \\
\hline Total OPEC & 402 & 8,493 & 153,597 & $-411,612$ & 228,509 & 380,096 \\
\hline Total Non-OPEC ME & 351 & 9,803 & 57,790 & 6,948 & 56,369 & 191,824 \\
\hline Total CPE & 3,108 & 13,890 & 31,170 & 37,482 & 312,005 & 382,979 \\
\hline Total & 3,861 & 32,186 & 242,557 & $-367,182$ & 596,883 & 954,899 \\
\hline
\end{tabular}

'Includes one half of the reserve additions in the Neutral Zone.

Notes: The mid point values of reserve ranges listed in Appendix $A$ are used in calculating the supplemental reserve additions. The entries in this table are the net of upward and downward reserve revisions and additions. These volumes for a given period are the difference between what was reported in that period and what was reported in prior periods. A listing of OPEC, CPE, and ME countries is contained in the Glossary.

Column totals may not add due to independent rounding.

MMbbls :- Million barrels of oll.

Bcf = Billion cubic teet of natural gas.

Sources: United States data are based on reserve additions from the Energy Information Administration U.S. Crude Oil, Natural Gas, and Natural Gas Liquids Reserves, 1989, 1988, 1987, and 1986 Annual Reports (DOE/ElA-0216), excluding natural gas liquids. Canadian data are taken frum Appendix A for the last 3 months, and Statistics Canada The Crude Petroleum and Natural Gas Industry, 1989, 1988, and 1987, excluding pentanes olus, for the last 12 and 36 months. All other foreign data are from the commercial information services of Petroconsultants, S.A., and supplemented with Appendix A. 
supply. CPE countries supplied 25 percent of the world's oil in the last 36 months. Comparing the last 12 months with the last 36 months of production, OPEC's percentage of the world production has increased, while the Non-OPEC ME and CPE percentages have decreased slightly. 


\section{Reserve Additions for the 2nd Quarter 1990}

The following is a list of significa it discoveries with reserve information reported in the second quarter of 1990 . The location and ultimate recovery estimate for each entry are depicted in Figures 5 through 8 . Entries in the list are grouped geographically.

\section{Europe (Figure 5.)}

- United Kingdom - Conoco intends to have the results of six additional appraisal wells in Murdoch gas field and other prospects in the area by the end of 1990 to aid in the development decision for Murdoch. Reserves are currently estimared at 200 to 300 billion cubic feet of gas.

- Norway - Saga will submit a development plan by the end of 1990 to install a subsea production system for the Tordis field. The 10()-million-barrel oil field is located south of Snorre field in the North Sea.

- Netherlands - Ranger Oil has completed appraisal of the Markham gas field in the North Sea. Production of the 5()() billion-cubic-foot gas field is scheduled to begin in 1992.

Asla, U.S.S.R., and Middle East (Figure 6.)

- India - ONGC discovered the Mori oil field in the Krishna-Godavari basin onshore in Andhra Pradesh. Reserves are estimated at 22 million barrels of oil.

- India - OIL has found commercial oil in Assam Pradesh. Reserves for the new find in the Dikom structure are estimated to be 22 million barrels of oil.

\section{Africa (Figure 7.)}

- Tunisia - British Gas will decide later this year on development of the offshore Miskar gas field. Negotiation of a gas sales agreement is of key importance to development. Field reser'es are estimated at 1 trillion cubic feet of gas.

- Libya - Agip found a new geologic structure between Attifel and Fimal oil fields. The new field has estimated reserves of 60 to 70 million barrels of oil.

- Fgypt - Shell plans to develop an oil discovery in Zeit Bay. The 25-million-barrel oil field will be produced through the Zeit Bay field production facilities at about 5,000 barrels per day.

- Angola - Elf has made a significant discovery offshore with its Cobo \#1 well. Industry analysts have indicated that the field contains 140 million barrels of recoverable oil.

- Equatorial Giunea - Offshore acreage contrining the Alba gas condensate field has been offered for license. Repsol discovered the Alba field in 1984 and relinquished the acreage after failing to find a market for the gas. Field reserves are estimated at 1.3 trillion cubic feet of gas and 68 million barrels of condensate.

- Nigeria - Agip has completed development and officially commissioned the offshore Agbara oil tield 73 miles southwest of Port Harcourt. Field reserves are estimated at 6.5 million barrels of oil. 


\section{Oceanla (Figure 8.)}

- Australia - Barrack Energy discovered gas with its Beharra Springs \#1 well. The new field is located just over a mile from a pipeline and has estimated potential reserves of 120 billion cubic feet of gas.

- Australia - Wapet h:s declared two small fields on the Northwest Shelf commercial. Production of the Cowle and Yammaderry fields will begin in 1991. Reserves are estimated at 4 million barrels of oil for each field with a production life of 4 years. 
Figure 5. European Reserve Additions for the 2nd Quarter 1990

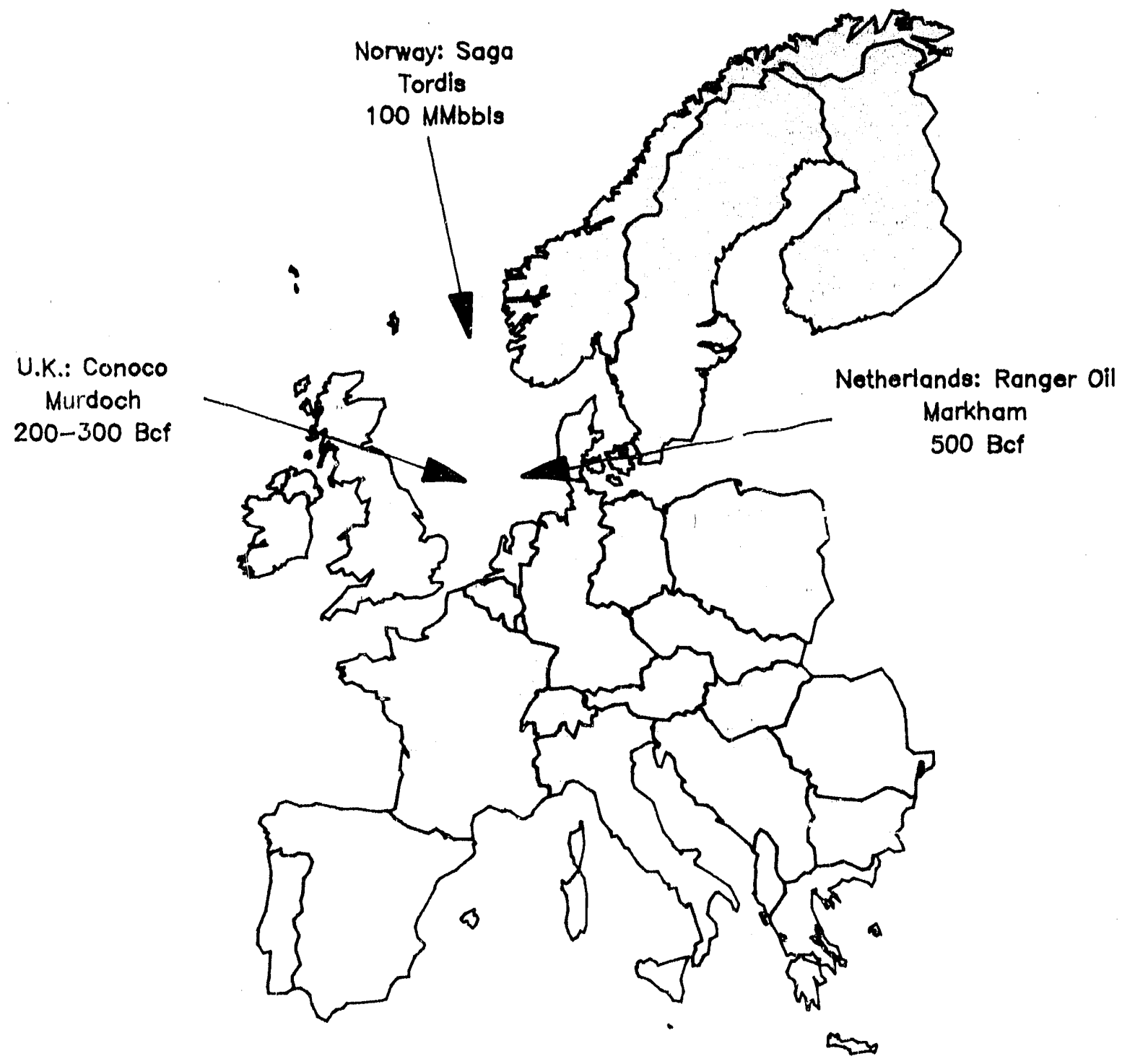

Source: Energy Information Administration, Office of Oll and Gas. 
Figure 6. Asian, U.S.S.R., and Middle Eastern Reserve Additions for the 2nd Quarter 1990

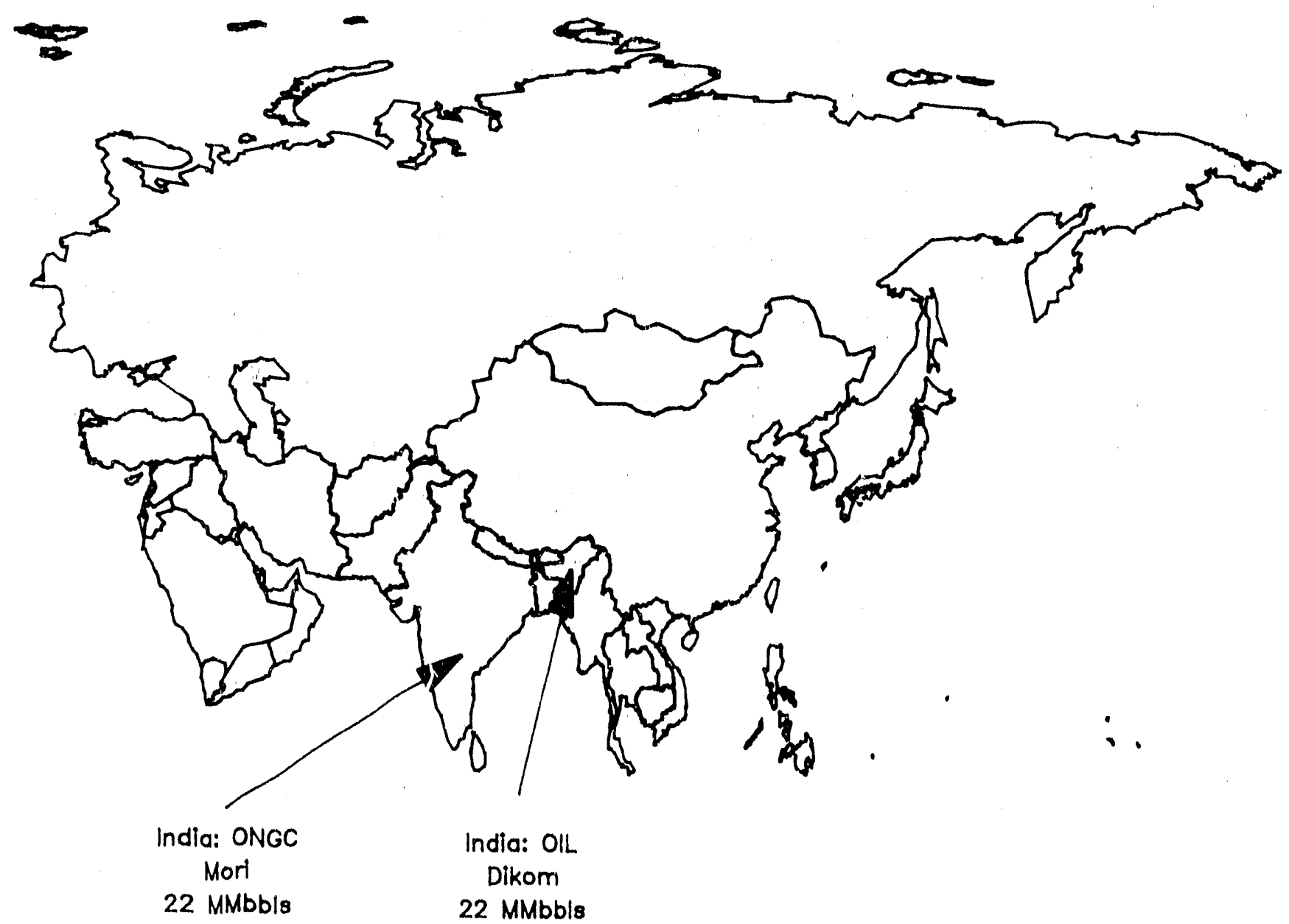

Source: Energy Information Administration, Office of Oll and Gas. 
Figure 7. African Reserve Additions for the 2nd Quarter 1990

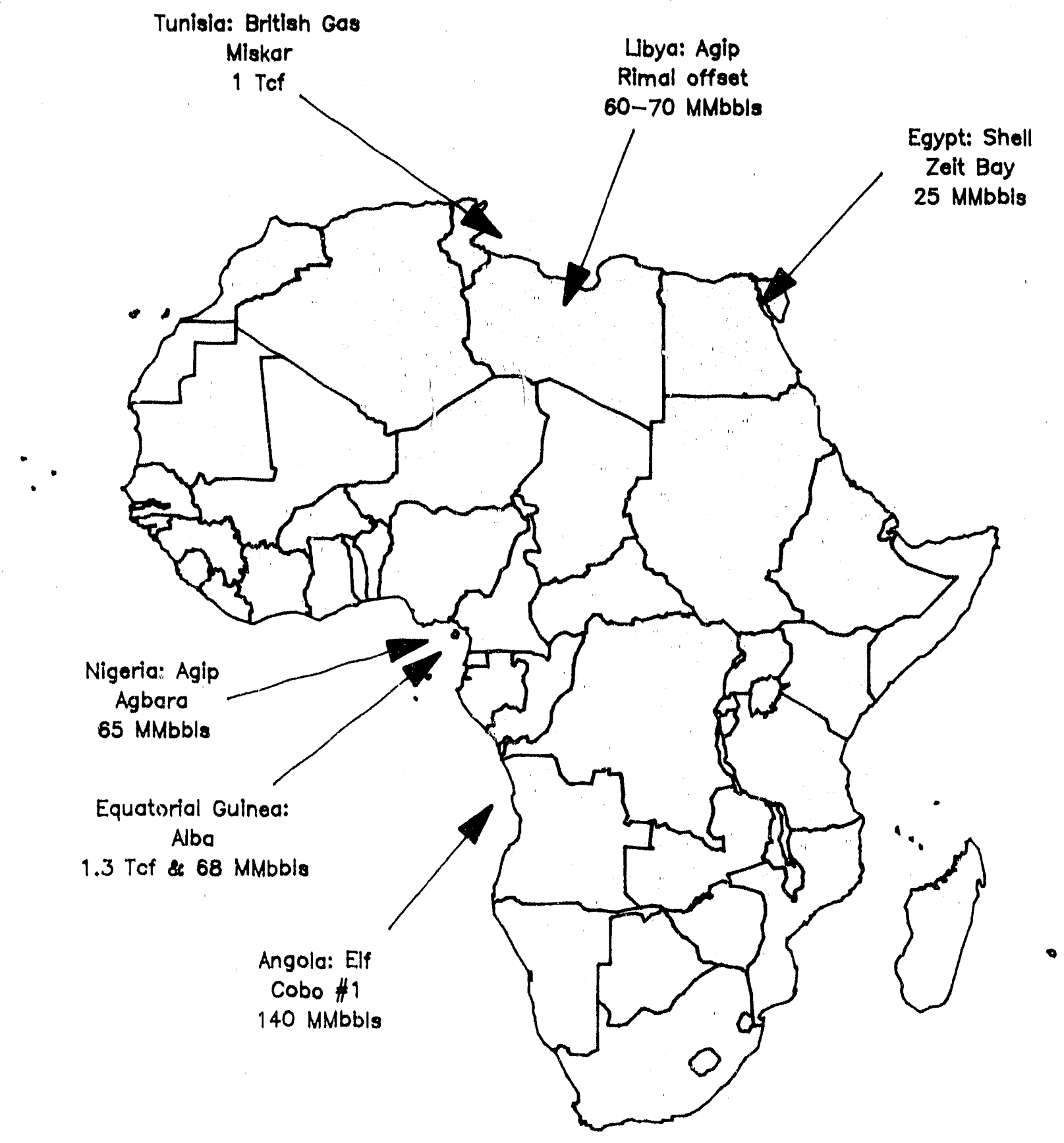

Source: Energy Information Administration, Offlce of Oll and Gos. 
Figure 8. Oceanian Reserve Additions for the 2nd Quarter 1990

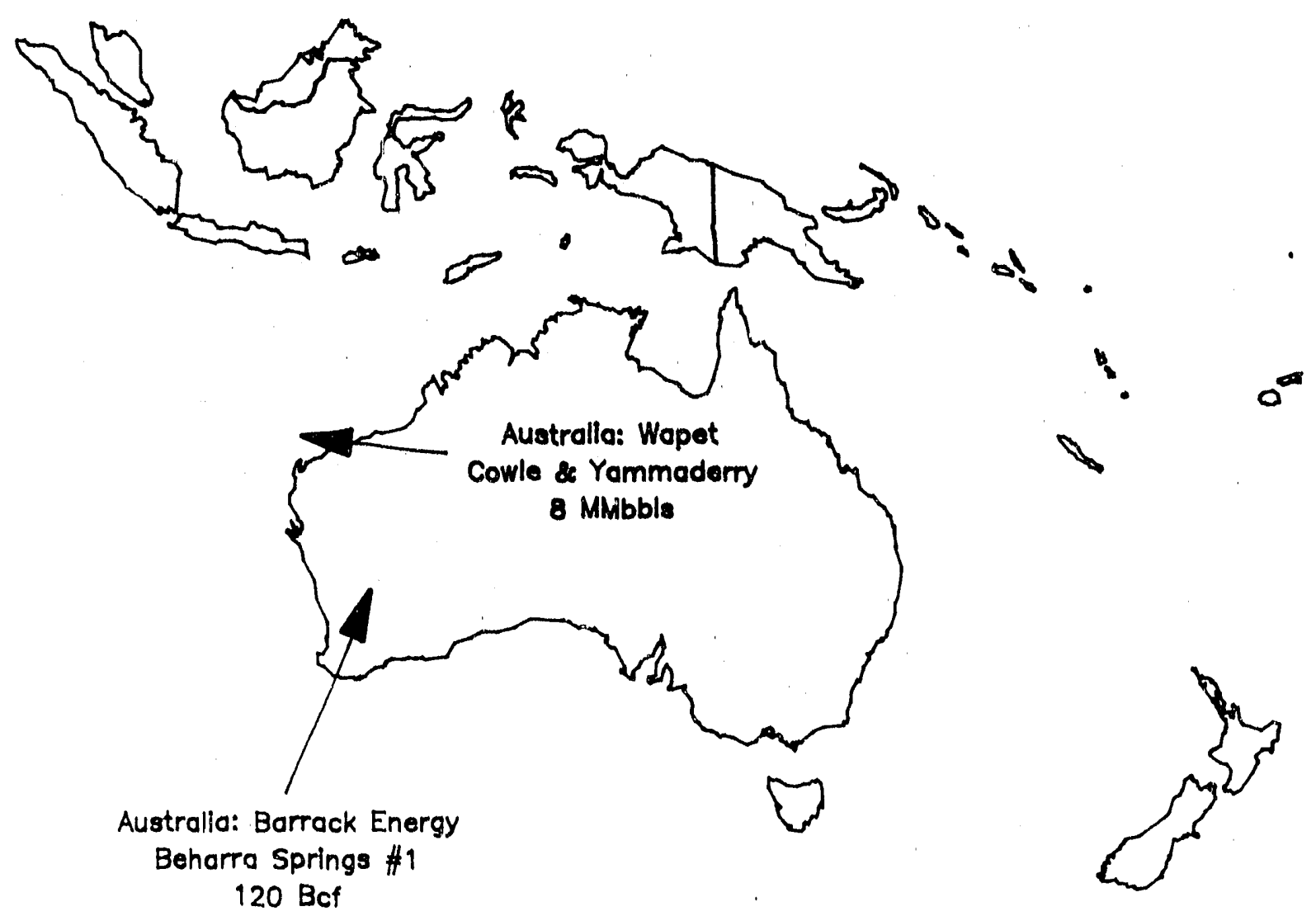

Source: Energy Information Adminiatration, Offlce of Oll and Gos. 


\section{References}

1. Oil and Gas Journal. "Prices Up, But Market Skeptical on CPEC Cuts." (May 14, 1990.) p. 24.

2. Petroleum Management. "The Month in the Oil Market." (June 1990.) p. 28.

3. Oil and Gas Journal. "Middle East Oil Producers Getting Set for Demand Surge in Mid-1990s." (April 9, 1990.) p. 21.

4. Oil and Gas. Journal. "Big E\&P Program Outlined in Saudi Arabia." (June 11, 1990.) p. 28.

5. Oil and Gas .Inurnal. "OGJ Newsletter." (June 25, 1990.).

6. World Oil. "Looking Ahead." (April 1990.) p. 13.

7. Oil and Gas Journal. "Middle East Presses Development." (April 16, 1990.) p. 22.

8. Oil and Gas.Journal. "International Briefs." (April 16, 1990.) p. 32.

9. Oil and (ras Journal. "International Briefs." (May 28, 1990.) p. 42.

10. Oil and (jas Journal. "International Briefs." (June 25, 1990.) p. 32.

11. World Oil. "International Insight." (May 1990.) p. 28.

12. Oil and Gas Journal. "Shell to Add Noble Rig in Nigeria." (June 4, 1990.) p. 26.

13. Oil and (Gas Journal. "OGJ Newsletter." (May 28, 1990.).

14. Oil and Gas .lournal. "West African Opportunities Draw Operators." (May 7, 1990.) p. 50.

15. Oil and (Gas Journal. "Soviet Venture May Include Tengiz." (June 11, 1990.) p. 18.

16. Oil and Gas. Journal. "Soviet Oil Exports Drop in Volume and Value." (April 30, 1990.) p. 26.

17. Oil and (ras Jourmal. "OPEC Cuts, N. Se:a Shutdowns Buoy Oil Prices." (May 21, 1990.) p. 20.

18. Oil and (ras. Iournal. "Stream of U.K. Offshore Developments Seen." (June 18, 1990.) p. 26.

19. ()il and (ias . Journal. "OGJ Newsletter." (June 18, 1990.).

20. World Oil. "Looking Ahead." (May 1990.) p. 13.

21. Oil and Gas Journal. "Steamflood Boosts Indonesia's Production and Proved Reserves." (June 25, 1990.) p. 48.

22. Oil and (ias Jourmal. "Rise in Indonesian Exploratory Drilling Seen." (June 11, 1990.) p. 20.

23. Oil and (ias. Journal. "OGJ Newsletter." (April 30, 1990.).

24. Petroleum Engincer International. "News Hi-lites." (June 1990.) p. 1.

25. Oil and (Fas Journal. "OCiJ Newsletter." (May 14, 1990.). 
Appendix A

Foreign Oil and Gas

Discoveries 


\section{Appendix A}

Table A1. Foreign Oll and Gas Reserve Discoverles

\begin{tabular}{|c|c|c|c|c|c|}
\hline Country/Field/Well & Company & $\begin{array}{l}\text { Disc } \\
\text { Date }\end{array}$ & $\begin{array}{l}\text { Report } \\
\text { Date }\end{array}$ & Source & Reserves and Comments \\
\hline \multicolumn{4}{|c|}{ NEW ENTRIES ARE BOXED AND SHAOED } & & \\
\hline Angola & & & & & \\
\hline
\end{tabular}

Abu Whabl

$\begin{array}{llllll}\text { •Bab \& Bu Hasa fields } & \text { Adco } & 1987 & 8 / 88 & \text { W. Oil } & 3.3 \text { Tcl deeper new gas resenroirs found } \\ \text {-Umm al-Anbar } & \text { Mubarraz Oil } & 1982 & 8 / 88 & \text { W. Oil } & 40 \text { MMbbls west of Mubarraz field offshore }\end{array}$

\begin{tabular}{|c|c|c|c|c|c|}
\hline 'Coorroo \#1 & Delhi Pet & 1986 & $1 / 87$ & Pol News & 3 MMbbls \\
\hline \multirow[t]{7}{*}{-Challis/Cassini } & BHP & 1984 & $8 / 87$ & W. Oil & 20.40 MMbbls Timor Sea \\
\hline & & & $2 / 88$ & OGJ & 40-50 MMbbls Timor Sea \\
\hline & & & $1 / 89$ & Ocn Ind & 25.45 MMbbls Timor Sea \\
\hline & & & $8 / 89$ & OGS & 42 MMbbls Timor Sea \\
\hline & & & $8 / 89$ & W. Oil & 75 MMbbls Timor Soa \\
\hline & & & $8 / 89$ & Pet Nows & 55 MMbbis Chalis onty Timor Sea \\
\hline & & & $1 / 90$ & Pot Nows & 42 MMbbis Timor Sea \\
\hline \multirow[t]{7}{*}{ - Jabiru } & $\mathrm{BHP}$ & 1983 & $8 / 87$ & W. Oil & 35.40 MMbbls Timor Sea \\
\hline & & & $2 / 88$ & OGJ & 30 MMbbls Timor Sea \\
\hline & & & $9 / 88$ & OGJ & 50 MMbbls Timor Sea \\
\hline & & & $1 / 89$ & Ocn Ind & 50-60 MMbbls Timor Sea \\
\hline & & & $8 / 89$ & OQJ & 82 MMbbls Timor Sea \\
\hline & & & $10 / 89$ & OQJ & 100 MMbbls Timor Sea \\
\hline & & & $1 / 90$ & Pet News & 82 MMbbls Timor Sea \\
\hline - Petrel & Elf Aquitaine & 1969 & $8 / 87$ & W. Oil & 6.7-15.5 Tci Timor Sea \\
\hline 'Tern & Elf Aquitaine & 1971 & $8 / 87$ & W. Oil & $1.2 .1 .8 \mathrm{Tcl}$ Timor Sea \\
\hline \multirow[t]{2}{*}{ 'N. Goodwyn } & Woodside & 1985 & $8 / 87$ & W. Oil & 200 MMbbls \& 2 Td NW Shelf \\
\hline & & & $10 / 87$ & AAPG & 200 MMibbls NW Shelf \\
\hline \multirow[t]{3}{*}{ 'Saladin } & Wapet & 1985 & $8 / 87$ & W. Oil & 20.30 MMbbls NW Shelf \\
\hline & & & $5 / 88$ & OGJ & 30-40 MMbbls Camarvon basin \\
\hline & & & $5 \longdiv { 9 0 }$ & Pot Engr & 20 MMbols offshore thevenard sland \\
\hline \multirow[t]{4}{*}{ 'Skua } & BHP Petroleum & 1986 & $2 / 88$ & OGJ & $20 \mathrm{MMbb} / \mathrm{s}$ \\
\hline & & & $8 / 88$ & W. Oil & $20.30 \mathrm{MMbbls}$ Timor Soa \\
\hline & & & $1 / 89$ & Ocn Ind & 40.50 MMbbls Timor Sea \\
\hline & & & $6 \longdiv { 8 0 }$ & OG & 30.5 MMbogs \\
\hline 'Bream & Esso.BHP & 1969 & $8 / 88$ & W. Oil & $35 \mathrm{MMbbls}$ Bass Strait \\
\hline 'Tanwhine & Esso. BHP & 1982 & $8 / 88$ & W. Oil & 7 MMbbls Bass Strait \\
\hline - Seahorse & Esso.BHP & 1978 & $8 / 88$ & W. Oil & 4.4 MMbbls Bass Strait \\
\hline "Whiting & Esso BHP & 1983 & $8 / 88$ & W. Oil & $21 \mathrm{MMbb} / \mathrm{s}$ Bass Strait \\
\hline \multirow[t]{2}{*}{-Talisman } & Marathon & 1984 & $9 / 88$ & OGJ & $10 \mathrm{MMbb} / \mathrm{N}$ NW Shelf \\
\hline & & & $1 / 89$ & Oen Ind & 10.15 MMbbls NW Shelf \\
\hline \multirow[t]{2}{*}{ 'Dolphin \& Perch fields } & Esso & 1967 & $12 / 88$ & Com Rpt & 19 MMbbls Bass Strait \\
\hline & & & $1 / 89$ & Ocn Ind & 19 MMbbls 13 MMbbls Perch , 6 MMbbis Dolphin Bass Strait \\
\hline \multirow[t]{2}{*}{ 'Echo \#1 } & Woodside & 1988 & $1 / 89$ & Ocn Ind & 1.2 Tcl $15.5 \mathrm{MMcld} \& 3858 \mathrm{bb} / \mathrm{d}$ cond Carnarvon basin \\
\hline & & & $4 / 89$ & Pet News & 1 Tef \& 150 MMbbls \\
\hline 'Bambra $z_{3}$ & Bond Corp & 1988 & $1 / 89$ & Oen Ind & 6 MMbbls \& $50 \mathrm{Bcl} 262$ bbVd \& 2 MMcld Carnarvon basin \\
\hline - Talbot & Sanios & 1989 & $1 / 90$ & Pot News & $40.50 \mathrm{MMbb} / \mathrm{s}$ Timor Sea \\
\hline "Yolla & Sagasco & 1985 & $2 / 90$ & Pot Engr & $270 \mathrm{Bcl}, 3 \mathrm{MMbb} / \mathrm{s}, \& 30 \mathrm{MMbbls}$ L.PG Bass Basin \\
\hline 'Cossack. Wanaea & Woodside & 1989 & $3 / 90$ & OGJ & 300 MMbbls Northwest SneH \\
\hline
\end{tabular}

See footnotes at end of table 
Table A1. Forelgn Oll and Gas Reserve Discoverles (Continued)

\begin{tabular}{|c|c|c|c|c|c|}
\hline Couniry/Fleld/Well & Company & $\begin{array}{l}\text { Disc } \\
\text { Date }\end{array}$ & $\begin{array}{l}\text { Report } \\
\text { Dale }\end{array}$ & Source & Reserves and Comments \\
\hline 'Grittin & BHP & 1989 & $3 / 90$ & OGJ & 100-150 MMMbbls Northwest SheH \\
\hline Beharra Springs H & Barrack Energy & 7900 & $\$ 60$ & ठब & T20 BC southwest Alstralia \\
\hline 'Cowle & Wapet & 1990 & $6 / 90$ & OGj & 4 MMibbls oftshore Northwest Shell \\
\hline LYammadary & Wapet & 1988 & $6 / 90$ & OQ & 4 MMbbls offshore Northwest Shat \\
\hline
\end{tabular}

\section{Bangladesh}

$\begin{array}{llllll}\text { 'Kailashtilla/Beanibazar } & \text { BOGMC } & 1962 & 8 / 87 & \text { W. Oil } & 40 \text { MMbbls Sylhet } \\ & & & 2 / 88 & \text { Pot News } 40 \text { MMbbls Sylhet } \\ \text { 'Fenchuganj } & \text { BOGMC } & 1987 & 2 / 89 & \text { Pet Nows } & 40 \text { MMbbls } \\ \text { Harip'.lr } & \text { BOGMC } & 1986 & 2 / 89 & \text { Pet News } & 40 \text { MMbbls First oil find in country } \\ \text { Jalalabad \#1 } & \text { Scimitar } & 1989 & 3 / 90 & \text { OGJ } & 1.5 \mathrm{Tct} \& 30 \text { MMbbls cond }\end{array}$

Brazil

'RJS-345 Covina

'Marlim

Petrobras

Petrobras

-Albacora

Petrobras

- Unicu

-Tubarao 1-PAS.4

'Merluza Field

"Malhado

4. RJS. 403

3.RNS. 120

1-RJS. 412

\section{Canada}

Amauligak

Gulf

Taglu

Terra Nova

Esso

Pelro Canada

Hibernia

Mobil

Whiterose E 09

Husky

$\begin{array}{lll}1986 & 8 / 87 & \text { W. Oil } \\ 1985 & 10 / 87 & \text { AAPG } \\ & 4 / 88 & \text { OGJ } \\ & 8 / 88 & \text { W. Oil } \\ 1984 & 10 / 87 & \text { AAPG } \\ & 5 / 88 & \text { OGJ } \\ & 8 / 88 & \text { W. Oil } \\ 1986 & 7 / 88 & \text { OGJ } \\ & 9 / 88 & \text { AAPG } \\ 1988 & 8 / 88 & \text { W. Oil } \\ 1984 & 9 / 88 & \text { AAPG } \\ & 8 / 89 & \text { W. Oil } \\ 1986 & 10 / 88 & \text { OGJ } \\ 1989 & 7 / 89 & \text { OGJ } \\ 1989 & 11 / 89 & \text { OGJ } \\ 1990 & 3 / 90 & \text { OGJ }\end{array}$

44 MMbbis Campos basin

1 Bbbls Campos basin

2.75 Bbols Campos basin

3.6 Bbbls \& 1.2 Tct Campos basin

500 MMbbls Campos basin

1.1 Bbbls Campos basin

1.1 Bbbls \& 2.3 Tcf Campos basin

150 MMbbls 40 API Upper Amazon

$150 \mathrm{MMbbls}$ oll, $250 \mathrm{MMbbls}$ cond, \& $3.5 \mathrm{Tcl}$

$100 \mathrm{MMbbls} 3200$ bbVd $50 \mathrm{API} \& 960$ Mcld of Parana state

$300 \mathrm{Bct} \& 10 \mathrm{MMbbls}$ cond Santos basin offshore

$350 \mathrm{Bcl} \& 10 \mathrm{MMbbls}$ cond Santos bain offshore

$30 \mathrm{MMbbl}$ Campos basin

125 MMbbls 500 MMbbls in place west of Marlim field

141 Bct \& 12 MMbbis cond off NE Brazil

100 MMbbls offshore Campos basin

\begin{tabular}{|c|c|c|c|}
\hline \multirow[t]{3}{*}{1986} & $8 / 87$ & W. Oil & $2 \mathrm{Tcl} S$. Alberta sour gas \\
\hline & $10 / 87$ & AAPG & 2. Tcf S. Alberta sour gas \\
\hline & $10 / 88$ & AAPG & $600 \mathrm{Bct}, 200 \mathrm{MM}$ bbls cond, \& 20 million metric tons sultur \\
\hline \multirow[t]{9}{*}{1984} & $8 / 87$ & W. Oil & 800 MMbbls Beautort Sea \\
\hline & $10 / 87$ & AAPG & 700.800 MMbbls Beautort S. 1a \\
\hline & 4/88 & OGJ & 500-600 MMbbls Beautort $\Sigma_{\theta a}$ \\
\hline & $8 / 88$ & OGJ & $500 \mathrm{MMbbls}$ Beautort Sea \\
\hline & $2 / 89$ & OGJ & $1.5 \mathrm{Tcl}$ Beautort Sea \\
\hline & 8,39 & OGJ & 450.500 MMbbls \& $2 \mathrm{Tcl}$ Beautort Sea \\
\hline & $3 / 90$ & OGJ & 335 MMbbls \& 2.2 Tcf Beautort Sea \\
\hline & ET90 & Com Rp & 500 MmbDls \& $2.5 \mathrm{TC}$ \\
\hline & $10 / 87$ & AAPG & $3 \mathrm{Tcl}$ Mackenzie Delta \\
\hline \multirow[t]{4}{*}{1984} & $12 / 87$ & AAPG & 500 MMbbls Jeanne D'Arc Basin \\
\hline & $3 / 88$ & OGJ & 130 MMbbls Jeanne D'Arc Basin \\
\hline & $5 / 88$ & OGJ & 150 MMbbls Jeanne D'Arc Basin \\
\hline & $2 / 90$ & Pet Engr & $400 \mathrm{MMbbls}$ \\
\hline \multirow[t]{3}{*}{1979} & $7 / 88$ & Com Rpt & 525.650 MMbbls $186 \mathrm{mi}$. east of St. Johris Newfoundland \\
\hline & $8 / 89$ & W. Oil & 500 MMbbls off St. John's, Newloundland \\
\hline & $6 / 90$ & Com Ror & 525 MाMEbाs \\
\hline 19 & $10 / 88$ & OGJ & 200.300 MMbbls 4999 bbVld \& 3.99 MMcid $6 / 9526-12086 \mathrm{H}$ \\
\hline
\end{tabular}

See loolnotes at and of table 
Table A1. Forelgn Oll and Gas Reserve Discoverles (Coitinued)

\begin{tabular}{|c|c|c|c|c|c|}
\hline Country/Fleld/Well & Company & $\begin{array}{l}\text { Disc } \\
\text { Date }\end{array}$ & $\begin{array}{l}\text { Report } \\
\text { Date }\end{array}$ & Source & Reserves and Comments \\
\hline Elmworth (B.C. ext) & Canadian Hunter & 1987 & $10 / 88$ & AAPG & 3.4 Tcf Elmworth extension into British Columbia \\
\hline Brassey & Canadian Hunter/BP & $11 / 87$ & $11 / 88$ & OQJ & 20 MMibbls Northeast British Coluinbla \\
\hline \multirow{2}{*}{ Parsons Lake } & Gulf & & $2 / 89$ & OGJ & 1.9 Tef Mackenzie Delta \\
\hline & & & $3 / 90$ & OGJ & 1.8 Tct \& 30 MMbble cond Mackenzie Delta \\
\hline$Y_{a} Y_{a}$ & & & $2 / 89$ & OGJ & 160 Bef Mackenzle Delta \\
\hline Inga & & & $2 / 89$ & OQN & 36 Mumbbls British Columbla \\
\hline Boundary Lake & Placer CEGO & & $3 / 89$ & OGJ & $200 \mathrm{Bcl} \& 2.5 \mathrm{MMbbls}$ i/2 zones $5700 \mathrm{H}($ sour qas) \& $6900 \mathrm{H}$ \\
\hline \multicolumn{6}{|l|}{ China } \\
\hline 'Xijiang 24-3.1 & Phillips & 1985 & $\begin{array}{l}4 / 87 \\
3 / 89\end{array}$ & $\begin{array}{l}\text { P. Times } \\
\text { OGJ }\end{array}$ & $\begin{array}{l}30.60 \text { MMbbls } \\
45 \text { MMbbls South China Sea }\end{array}$ \\
\hline & & 1986 & $10 / 87$ & AAPG & 293 MMbbls Henan Province \\
\hline \multirow{2}{*}{$\begin{array}{l}\text { Nanyang } \\
\text { 'Huizhou 21-1 }\end{array}$} & ACT & 1985 & $2 / 88$ & Pot Nows & 30 Mubbls South China Sea \\
\hline & & & $3 / 90$ & OQJ & 127 MMbbls South China Sea Pearl River basin \\
\hline \multirow[t]{4}{*}{ 'Suizhong 36.1} & Bohai Oil & 1986 & $2 / 88$ & Pet Nows & 900 MMbbls Luadong Bay \\
\hline & & & $3 / 88$ & OQJ & 1022 MMbbls Ladong Bay \\
\hline & & & $10 / 88$ & OGJ & 800 MMbbls 1.2 Bbbls In place 17 API heavy oll \\
\hline & & & $1 / 89$ & Oen Ind & 900 MMbbls 17 API Liadong Bay \\
\hline 'BZ 34-2/4E & JCODCO & 1983 & $2 / 88$ & Pet Nows & 35 MMbbls Bohal \\
\hline \multirow{2}{*}{ Luteng 13.1} & JHN & 1987 & $2 / 88$ & Pet Nows & 30-40 MMbbls South Cittna Sea \\
\hline & & & $4 / 89$ & Pet Nows & $30.60 \mathrm{MMbb} / \mathrm{s}$ \\
\hline Dagang & & 1964 & $3 / 88$ & OGJ & 730 MMbbls adcled Kongdian area \\
\hline Bonan & & 1987 & $3 / 88$ & OGJ & 1095 MMbbls Shengli basin \\
\hline Xixiapo Area & & 1987 & $3 / 88$ & OGJ & $2.92 \mathrm{Bbb} / \mathrm{s}$ \\
\hline "Huoshaoshan & & 1983 & $3 / 88$ & OGJ & 730 MMbbls Xinjlang Province Junggar basin \\
\hline \multirow[t]{2}{*}{ 'Liuhua $11-1$} & Amoco & 1987 & $8 / 88$ & OGJ & 730 MMbbls 21 API $1000 \mathrm{Ht}$ of water \\
\hline & & & $4 / 89$ & Pet Nows & 700 MMbbls \\
\hline Zhongyuan & & 1988 & $9 / 88$ & OGJ & 1.4-2.1 MMbbls added for new pay \& new fields in area \\
\hline \multirow[t]{3}{*}{ 'Yacheng 13.1} & ARCO/Cnove & 1983 & $1 / 89$ & OGJ & 2.1-3.53 Tct South of Hainan Island \\
\hline & & & $4 / 89$ & Pot Nows & $3.5 \mathrm{Tcf}$ \\
\hline & & & $8 / 89$ & OGJ & 2.47-3.53 Tct Hainan Island \\
\hline Moxi & & 1987 & $2 / 89$ & Pot Nows & 897 Bct Sichuan Province \\
\hline 'Aershan & & & $2 / 89$ & Pet Nows & 558.3 MMbbls Ertian Basin Inner Mongolla \\
\hline Gold Family & Bohai Dil & 1988 & $2 / 89$ & Pot nows & 183 MMbbls near Zibo in Huantal county S side of Yellow River \\
\hline - Jinzhou $20-2$ & Cnooc & 1984 & $3 / 89$ & OGJ & 533 MMbbls, 22 MMbbls cond, \& 706 Bet north Bohal Sea \\
\hline 'Bozhong 28.1 & JCODC & 1981 & $3 / 89$ & OGJ & 30 MMbbls south central Bohal Soa \\
\hline 'Liuhua $4 \cdot 1$ & & 1987 & $4 / 89$ & Pot Nows & $30 \mathrm{MMbb} / \mathrm{s}$ \\
\hline Yinggehai & ARCO & & $1 / 90$ & OGJ & 3 Tcf offshore Hainan Island \\
\hline 'Kekkeya & & 1977 & $1 / 90$ & OG. & 250 MMbbls \& 1.02 Tet SW Tarim basin \\
\hline
\end{tabular}

Colombia

\begin{tabular}{|c|c|c|c|c|c|}
\hline Amazonas Basin & Ecopetrol & & $8 / 87$ & W. Oil & $40 \mathrm{MMbb} / \mathrm{s} \& 10 \mathrm{Bct}$ \\
\hline \multirow[t]{2}{*}{ - Cano Limon } & Oxy & 1983 & $8 / 87$ & W. Oil & $1 \mathrm{Bbbis}$ \\
\hline & & & $2 / 88$ & AAPG & 1.5 Bbbls Colombia \& Venezuela \\
\hline \multirow[t]{3}{*}{ 'Rubiales } & Tuskar Resources & 1981 & $4 / 89$ & OGJ & 70-100 MMbbls southern Llanos basin \\
\hline & & & $8 / 89$ & W. Oil & $250 \mathrm{MMbb} / \mathrm{s}$ heavy oil \\
\hline & & & 490 & DG & उ50 MMEDIs \\
\hline 'Baicon & Ecopetrol & $8 / 88$ & $8 / 89$ & W. Oil & 160 MMbbls Upper Magdaisna Valley basin \\
\hline
\end{tabular}

Cote d'Ivolre

•Foxtrol Phillips $19828 / 89$ OGJ 940 Bet gas in place offshore 50 mi sw of Abidjan

See fontnoles at end of table. 
Table A1. Forelgn Oll and Gas Reserve Discoveries (Continued)

\begin{tabular}{|c|c|c|c|c|c|}
\hline Country/Fleld/Well & Company & $\begin{array}{l}\text { Disc } \\
\text { Date }\end{array}$ & $\begin{array}{l}\text { Report } \\
\text { Date }\end{array}$ & Source & Reserves and Comments \\
\hline \multicolumn{6}{|l|}{ Denmark } \\
\hline 'Dagmar & DUc & 1983 & $6 / 89$ & OGJ & 19 MMbbls offshore 1st Danish North Sea field with sour gas \\
\hline 'Gorm & DUC & 1971 & $8 / 89$ & OGJ & 20 MMbbls \& 15 Tet \\
\hline "Valdemar & DUC & 1977 & $8 / 89$ & $O Q J$ & $30 \mathrm{MMbb} / \mathrm{s} \& 210 \mathrm{Bct}$ \\
\hline "Harald & DUC & 1980 & $8 / 89$ & OGS & $900 \mathrm{Bct} \& 50 \mathrm{MMbb} / \mathrm{s}$ \\
\hline "Gent & DUC & 1987 & $8 / 89$ & OQJ & 120 MMbbls 50 MMbbls on Danish side 70 MMbbls on Nonvegian \\
\hline \multicolumn{6}{|l|}{ Ecuador } \\
\hline 'Payamino & CEPE & 1987 & 10/89 & OQJ & 24 MMbbls \\
\hline 'Cantagallo & Petro del Ecuador & 1988 & $12 / 89$ & OGJ & 45 MMbbls Oriente region \\
\hline 'Tiguino & Petro del Ecuador & 1971 & $12 / 89$ & OGJ & $25 \mathrm{MMbb} / \mathrm{s}$ Orienter region \\
\hline -Pucuna & Petro del Ecuador & 1972 & $12 / 89$ & OGJ & 20 MMbbls Oriente region \\
\hline 'Coca-Payamino & Petro del Ecuador & 1971 & $12 / 89$ & OGJ & 16 MMbbls Oriente region \\
\hline 'Paraiso' & Petro del Ecuador & 1987 & $12 / 89$ & OGJ & $4 \mathrm{MMbbls}$ Oriente region \\
\hline 'Frontera & Petro del Ecuador & 1987 & $12 / 89$ & OGJ & $3 \mathrm{MMbb} / \mathrm{s}$ Oriente region \\
\hline \multicolumn{6}{|l|}{ Egypt } \\
\hline "Meleiha Permit & Agiba & 1972 & $8 / 87$ & OGJ & 63 MMbbls Westem Desent \\
\hline 'Sinai $\# 1$ & Petrobel & 1987 & $10 / 88$ & $A A P G$ & 20 MMbbls oftshore GuH of Suez \\
\hline 'Badr al.Din & Shiell & 1982 & $8 / 89$ & W. 에 & 99 MMbbls Western Desert \\
\hline Magawish & Total & & $8 / 89$ & W. Oil & 55 MMbbbls southern Gulf of Suez \\
\hline Leil Bay salellite & Shell & 1990 & $5 / 90$ & OG & 25 Mutbo/s ofishore ZoltBay \\
\hline
\end{tabular}

Equatorial Guinea

TAlba 1984.490 वG

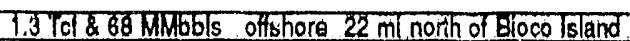

France

$\begin{array}{llllll}\text { 'Fontaine-au-Bron } \quad \text { Elf } & 1986 \quad 10 / 88 & \text { Com Rpt } & 4.2 \text { MMbbls }\end{array}$

Gabon

\begin{tabular}{|c|c|c|c|c|c|}
\hline \multirow{6}{*}{$\begin{array}{l}\text { "Kounga \#1 } \\
\text { "Rabi/Kounga }\end{array}$} & ShelveH & $7 / 86$ & $8 / 87$ & W. Oil & 360 MMbbls \\
\hline & Shell & 1985 & $10 / 87$ & AAPG & $500.600 \mathrm{MMbb} / \mathrm{s}$ \\
\hline & & & $2 / 88$ & AAPG & $1.3 \mathrm{Bbbls}$ \\
\hline & & & $5 / 88$ & OGJ & $500.600 \mathrm{MMbb} / \mathrm{s}$ \\
\hline & & & $8 / 88$ & W. Oil & $370 \mathrm{MMbb} / \mathrm{s}$ to $1.2 \mathrm{Bbbls}, 2 \mathrm{Bbbls}$ possible \\
\hline & & & $11 / 88$ & OGJ & $42.8 \mathrm{MMbbls}$ \\
\hline 'Rabi & Shell & & $11 / 87$ & OGS & $370 \mathrm{MMbbls}$ \\
\hline 'Echira \& Niungo & ShellVEH & $84 / 88$ & $12 / 89$ & OGJ & 36.5 MMbbls \\
\hline
\end{tabular}

Indla

$\begin{array}{llllll}\text { 'Gandhar } & \text { ONGC } & 1983 & 8 / 87 & \text { W. Oil } & 700 \text { MMbbls Gujarat State } \\ \text { 'Neelam } & \text { ONGC } & 1987 & 8 / 88 & \text { OGJ } & 314 \text { MMbbls oftshore western India } \\ \text { 'Mid Tapti } & \text { ONGC } & 1982 & 2 / 89 & \text { Pet News } & \text { ? ?6 Bef Gulf ol Khambhat (Cambay) } \\ \text { 'South Tapti } & \text { ONGC } & 1978 & 2 / 89 & \text { Pet News } & 230 \text { Bdf Gulf of Khambhat (Cambay) }\end{array}$

See tootnotes at end of table. 
Table A1. Foreign Oll and Gas Reserve Discoveries (Continued)

\begin{tabular}{|c|c|c|c|c|c|}
\hline Country/Field/Well & Company & $\begin{array}{l}\text { Disc } \\
\text { Date }\end{array}$ & $\begin{array}{l}\text { Report } \\
\text { Date }\end{array}$ & Source & Reserves and Comments \\
\hline 'Panna & ONGC & 1976 & $2 / 89$ & Pet News & $93 \mathrm{MMbb} / \mathrm{s} \& 244 \mathrm{Bcf}$ western oftshore region \\
\hline 'Tanot \#1 & OlL & 1988 & $8 / 89$ & W. ON & 27 Bof located in Rajasthan \\
\hline Mor & ONGC & 1960 & 480 & OGJ & 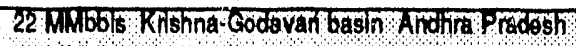 \\
\hline Dlkom & ONL & 1990 & $5 / 90$ & QQJ & 23 MNMbblo Asosm Prodesh \\
\hline
\end{tabular}

Indonesia

\begin{tabular}{|c|c|c|c|c|c|}
\hline 'Tunu & Total & 1977 & $10 / 87$ & AAPG & $10 \mathrm{Tct}$ Mahakam Delta \\
\hline 'Bima & ARCO & 1983 & $10 / 87$ & AAPG & 150 MMbbls NW Java \\
\hline \multirow[t]{2}{*}{ "IntanWidur' } & Maxus & 1987 & $6 / 88$ & OGJ & 275 MMbbls SE Sumatra \\
\hline & & & $2 / 89$ & Pot Nows & 225 MMbbls Widuri onty SE Sumatra \\
\hline \multirow[t]{3}{*}{ •Pagenungan } & ARCO & 1985 & $5 / 89$ & Com Rpt & 1.5 Tof offshore Bali \\
\hline & & & $8 / 89$ & Com Rpt & $1.4 \mathrm{Tct}$ \\
\hline & & & 559 & पढ़्ग & 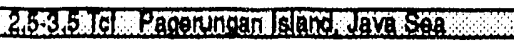 \\
\hline Northeast intan & Maxus & 1989 & $10 / 89$ & OGJ & 10 MMbbls off SE Sumatre \\
\hline 'Belanak & Conoco & 1982 & $12 / 89$ & OQN & 1 Tof W of Natuna Island S Chine Sea Block B \\
\hline TMinas & Calfex & T944. & 6790 & OG & 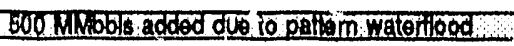 \\
\hline
\end{tabular}

Iran

Koohe Mand

Behbahan

$1988 \quad 12 / 88$ OGJ

$1988 \quad 12 / 88 \quad$ OGJ

10 Bbbls very heavy crude southeast of Bushire

Lamard

1989 10/89 तGJ

MMbbls east of Behbahan

Iraq

-East Baghdad

'Khabbaz

Anfal

Italy

-Villatortuna

'Irminio

Agip

Selm

Jordan

'Risha

NRA

Kuwait

"Magwa \& Minagish Fields

Magwa field area well

Libya

'Bouri

Agip

$\begin{array}{lll}1979 & 5 / 89 & \text { OGi } \\ & 8 / 89 & \text { W. Oil } \\ 1983 & 12 / 89 & \text { OGJ } \\ & 12 / 89 & \text { OGJ }\end{array}$

$7 \mathrm{Bbbls}$

10.8 Bbbls 22-24 API

2 Bbbls

4.5 Tct northern Iraq near Kirkuk $\begin{array}{llll}1984 & 6 / 88 & \text { OGJ } & <300 \text { MMbbls } 45 \text { API t/18700 ft River Tlcino } \\ 1982 & 8 / 89 & \text { W. Oil } & 20-40 \text { MMbbls \& } 10 \text { Bct SE Slaly }\end{array}$

$\begin{array}{llll}7 / 87 & 10 / 88 & \text { AAPG } & 1 \mathrm{Tct} 15 \mathrm{MMctd} \\ 3 / 90 & \text { OGJ } & 500 \mathrm{Bct}\end{array}$

1987 8/88 W. Oil 1 Bbbls I Marat outpost well

See footnoles at end of table.

Energy Information Administration/International Oll \& Gas

Exploration \& Development Activities Second Quarter 1990 
Table A1. Foreign OIl and Gas Reserve Discoverles (Continued)

\begin{tabular}{|c|c|c|c|c|c|}
\hline Country/Field/Weil & Company & $\begin{array}{l}\text { Disc } \\
\text { Date }\end{array}$ & $\begin{array}{l}\text { Report } \\
\text { Date }\end{array}$ & Source & Reserves and Comments \\
\hline & & & $\begin{array}{l}5 / 88 \\
9 / 88 \\
10 / 88 \\
1 / 89\end{array}$ & $\begin{array}{l}\text { Pot Mngt } \\
\text { OGJ } \\
\text { AAPG } \\
\text { OQJ }\end{array}$ & $\begin{array}{l}500.700 \text { MMbbls } \\
670 \text { MMbbls } \\
500 \text { MMbbls } \\
2.5 \text { Bbbls \& } 1.25 \text { Tct } 5 \text { Bbbls \& } 2.5 \text { Tct in place }\end{array}$ \\
\hline Anlinal offset. & Adip. & 1920 & 890 & ठदा & 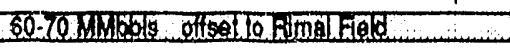 \\
\hline
\end{tabular}

\section{Malaysla}

$\begin{array}{llllll}\text { 'Seligi } & \text { Petronas } & 1971 & 1 / 89 & \text { Ocn Ind } & 420 \text { MMbbls } 171 \text { mi off Trengganu largest in country } \\ \text { - Jerneh } & \text { Esso } & 1969 & 7 / 89 & \text { Oil Dly } & 3 \text { Tct largest gas field In country off Trengganu } \\ \text { Block S8.1 } & \text { Shell } & 1988 & 8 / 89 & \text { W. Oil } & 150-200 \text { MMbbls off Kola KInabalu, Sabah }\end{array}$

\section{Myanmar}

\begin{tabular}{|c|c|c|c|c|c|c|}
\hline \multirow[t]{3}{*}{ Martaban } & \multirow{3}{*}{\multicolumn{2}{|c|}{ JNOC }} & $1 / 87$ & Pet News & 4 Tof & Gulf of Martaban \\
\hline & & & $8 / 87$ & W. OIl & 3.7 Tcf & Gulf of $\mathrm{Ma}$ \\
\hline & & & $11 / 89$ & Pet Nows & $4.3 \mathrm{Tcf}$ & Gulf of $N$ \\
\hline -3Da Structure & Myanma Oil Corp & 1983 & $2 / 89$ & Pot News & $4.3 \mathrm{Tct}$ & Gult of $\mathrm{MB}$ \\
\hline
\end{tabular}

Namibla

\begin{tabular}{|c|c|c|c|c|c|}
\hline \multirow[t]{2}{*}{ "Kudu } & SW Airican O\| Expl & 1974 & $8 / 87$ & W. Oil & 3-10 Tct \\
\hline & & & $8 / 89$ & W. Oil & 2 Tct off Orange River mouth \\
\hline
\end{tabular}

Netherlands

\begin{tabular}{|c|c|c|c|c|c|c|c|}
\hline$\cdot F / 15.4,5$ & Petroland & 1986 & $8 / 87$ & W. oil & $420 \mathrm{Bcf}$ & & \\
\hline${ }^{\circ} \mathrm{F} / 16.5$ & Statoil & 1986 & $10 / 87$ & AAPG & $<75$ MMbbls & North Sea & \\
\hline$* / 5 a$ & Elf Petroland & 1988 & $10 / 88$ & OGJ & $100 \cdot 200 \mathrm{Bct}$ & 36 MMcld & southern gas basin \\
\hline${ }^{\circ} K / 6$ & Petroland & 1936 & $5 / 89$ & OGJ & $353 \mathrm{Bct}$ & & \\
\hline Manhiam & Ranger Of & 1984 & $6 / 90$ & ठGJ & $500 \mathrm{BCT}$ DU & chNorth 50 & \\
\hline
\end{tabular}

New Zealand

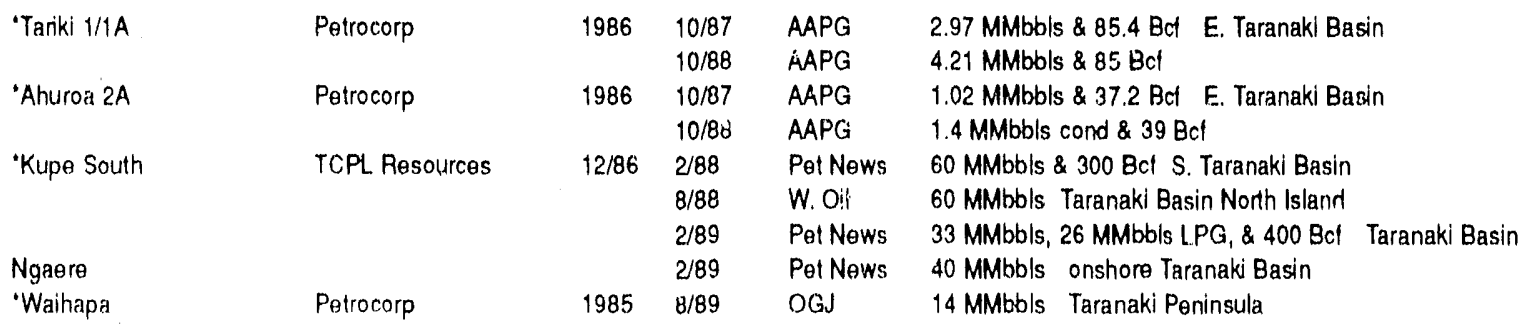

Nigerla

TTunu 41

'Bonin Estuary \#1 Bidll

Ososo \#1 Shell

-Gbetiokun \#1 Shell

'Opomoyo \#1 Shell

$\begin{array}{llll}1988 & 8 / 88 & \text { Oil Dly } & 65 \text { MMbbls } \\ 1988 & 8 / 88 & \text { Oil Dly } & 15 \text { MMbb!s \& } 100 \text { Bct } \\ 1988 & 8 / 88 & \text { Oil Dly } & 150 \text { Bct } \\ 1987 & 8 / 88 & \text { W. Oil } & 50 \text { MMbbls } \\ 1988 & 8 / 88 & \text { W. Oil } & 30 \text { MMbbls }\end{array}$

See footnotes at end of table 
Table A1. Foreign Oll and Gas Reserve Discoverles (Continued)

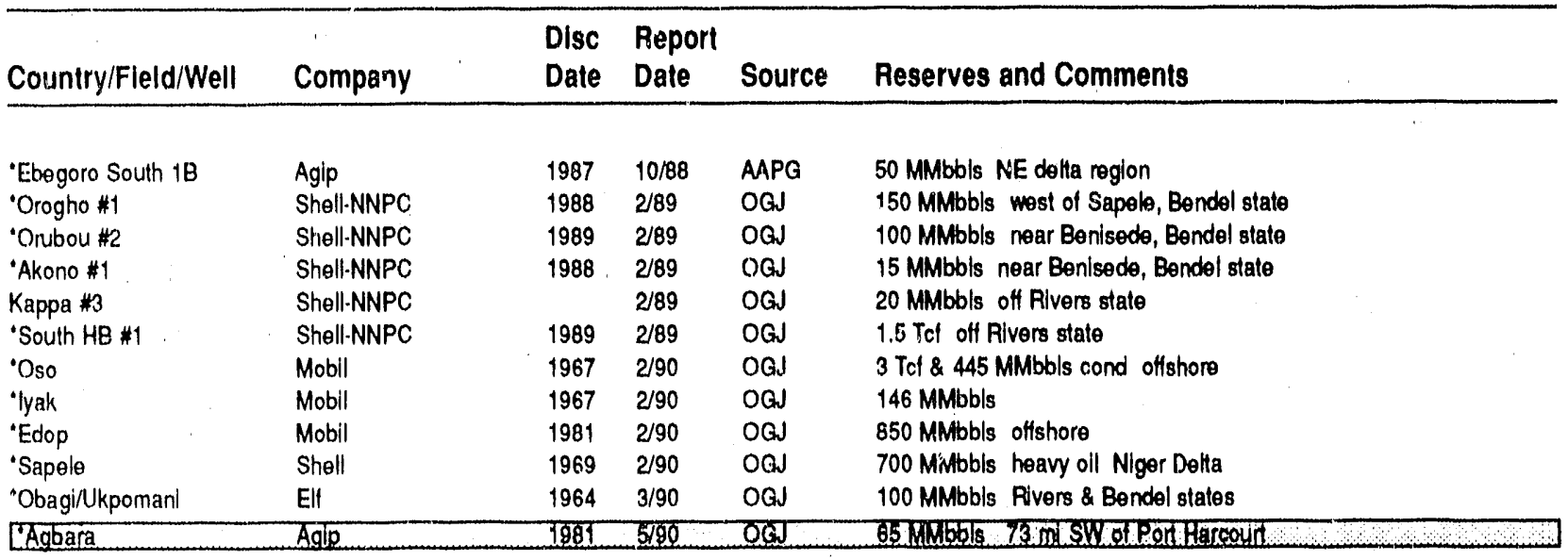

Norway

\begin{tabular}{|c|c|c|c|c|c|}
\hline \multirow[t]{7}{*}{ ‘Heidrun } & Conoco & 1985 & $8 / 87$ & W. 에 & 745 MMbbls \& $1.3 \mathrm{Tc} f$ \\
\hline & & & $4 / 89$ & W. OIl & 752 MMbbls \& $1.1 \mathrm{Tct}$ \\
\hline & & & $8 / 89$ & OGJ & 750 MMbbls \& 1.4 Tot Hallenbanken area \\
\hline & & & $10 / 89$ & OGJ & 756 MMbbls \& 1.06 Tof Haltenbanken area \\
\hline & & & $1 / 90$ & OQJ & 750 MMbbls \& 1-1.5 Tof Haltenbanken area \\
\hline & & & $2 / 90$ & JPT & $550 \mathrm{MMbbls} \& 1.02 \mathrm{Tct}$ \\
\hline & & & 5590 & का & 750 MWbols \& T T \\
\hline \multirow[t]{4}{*}{ "Draugen } & & 1984 & $8 / 87$ & W. Oil & $400 \mathrm{MMbbls} \& 60 \mathrm{Bcl}$ \\
\hline & & & $2 / 88$ & AAPG & 1 Bbbls \\
\hline & & & $11 / 88$ & OGJ & 422. MMbbls \& 106 Bcf \\
\hline & & & $8 / 89$ & OGJ & 400 MMbbls \& 60 Bcf Hattenbanken area \\
\hline \multirow[t]{4}{*}{ 'Snorra } & & 1979 & $8 / 87$ & W. Oil & 700 MMbbls \& $250 \mathrm{Bd}$ \\
\hline & & & 4/89 & W. Oil & 722 MMbbls \& $314 \mathrm{Bcf}$ \\
\hline & & & $7 / 89$ & OGN & $667.680 \mathrm{MMbbls}$ \\
\hline & & & $8 / 89$ & OGJ & $680 \mathrm{MMbb} / \mathrm{s} \& 250 \mathrm{Bct}$ \\
\hline Haltenbanken Area & & & $2 / 88$ & AAPG & 1.9 Bbbls \\
\hline \multirow[t]{2}{*}{ "Veslefrikk } & Statoil & 1981 & $8 / 88$ & Pel Engr & $230 \mathrm{MMbbls}$ block $30 / 3$ \\
\hline & & & $4 / 89$ & W. Oil & $191 \mathrm{MM}$ bbls \& $124 \mathrm{Bct}$ \\
\hline$\cdot 34 / 7.12$ & Saga & 1987 & $8 / 88$ & W. Oil & $200.500 \mathrm{MMbbls} 9385 \mathrm{bb} / \mathrm{d}$ \\
\hline $34 / 7-13$ & Saga & 1988 & $8 / 88$ & W. Oil & $30.60 \mathrm{MMbbls} 8491 \mathrm{bbVd}$ \\
\hline \multirow[t]{2}{*}{ "North Slafjord 33/9-4 } & Statoll & 1977 & $8 / 88$ & W. Oil & $120 \mathrm{MMbbbls} 8900 \mathrm{bbV} / \mathrm{d}$ \\
\hline & & & $11 / 88$ & OGJ & 126 MMbbls \\
\hline 'East Stattjord & Statoil & 1976 & $11 / 88$ & OQJ & $95 \mathrm{MMbbls}$ \\
\hline \multirow[t]{2}{*}{ •Ula } & $\mathrm{BP}$ & 1976 & $12 / 88$ & OGJ & 80 MMbbls Upward Revision $1 / 250-330$ MMbbls \\
\hline & & & $10 / 89$ & OGJ & 90 MMbbls added, 420 MMbbls total Block $7 / 12$ \\
\hline \multirow[t]{3}{*}{ 'Oseberg } & Norsk Hydro & 1979 & $4 / 89$ & W. Oil & 125 MMbbls \\
\hline & & & $5 / 89$ & OGJ & $1.57 \mathrm{Bbbls} 80 \mathrm{mi}$ west of Bergen \\
\hline & & & $2 / 90$ & Pet Mngt & 1.46 Gbbls \\
\hline 'Gyda & $\mathrm{BP}$ & 1980 & $4 / 89$ & W. Oil & 212 MMbbls \& 116 Bct \\
\hline • Hod & Amoco & 1974 & $4 / 89$ & W. Oil & $37 \mathrm{MMbb} / \mathrm{s} \& 141 \mathrm{Bct}$ \\
\hline -Sleipner & Statoil & 1974 & $4 / 89$ & W. Oil & 175 MMbbls \& $1.75 \mathrm{Tct}$ \\
\hline - East Troll & Statoil & & $4 / 89$ & W. Oll & 13.2 Tct \& 34 MMbbls \\
\hline \multirow[t]{2}{*}{ •Troll } & Statoil & 1979 & $6 / 89$ & OGJ & 43.8 Tct includes both East \& West Troll \\
\hline & & & $8 / 89$ & OGJ & $45.5 \mathrm{Tct}$ \\
\hline \multirow[t]{3}{*}{ ·West Flark, Troil } & Statoil & & $6 / 89$ & OGJ & 258 MMbbls western rim of Troll \\
\hline & & & $1 / 90$ & OGJ & 260 MMbbls western lobe of Troll \\
\hline & & & 590 & DGJ & 4TI MMbob sostern province \\
\hline \multirow[t]{3}{*}{ 'Brage } & Norsk Hydro & 1980 & $6 / 89$ & OGJ & 243 MMbbls \& 98 Bef offshore \\
\hline & & & $2 / 90$ & OGJ & 240 MMbbls \& $12 \mathrm{Bct}$ \\
\hline & & & $3 / 90$ & Pot Mngt & $240 \mathrm{MMbbls} \& 40 \mathrm{Bct}$ \\
\hline Njord 6407/7.1 & Norsk Hydro & 1986 & $8 / 89$ & OGJ & 250 MMbbls \& 300 Bef Haltenbanken area \\
\hline
\end{tabular}

Sefe tootnctes al end of table. 
Table A1. Forelgn Oil and Gas Reserve Discoveries (Continued)

\begin{tabular}{|c|c|c|c|c|c|}
\hline Country/Fleld/Well & Company & $\begin{array}{l}\text { Disc } \\
\text { Date }\end{array}$ & $\begin{array}{l}\text { Report } \\
\text { Date }\end{array}$ & Source & Reserves and Comments \\
\hline $6407 / 7-4$ & Norsk Hydro & 1989 & $8 / 89$ & W. Oil & 250 MMbbis \& 353 Bct \\
\hline 'East Sleipner & & 1981 & $8 / 89$ & W. Oll & $1.8 \mathrm{Tol} \& 406 \mathrm{MMbbls}$ \\
\hline 'Odin & Esso & 1974 & $8 / 89$ & Pot Engr & 1.2 Tof North Sea Block 30/40 \\
\hline \multirow[t]{2}{*}{ 'Froy } & Elf & 1988 & $8 / 89$ & Pot Engr & 100-125 MMbbls \& $200 \mathrm{Bcl}$ North Sea Block 25/5 \\
\hline & & & $2 / 90$ & OQJ & 95-125 MMbbls \\
\hline 'GuHtaks & Statoil & 1978 & $12 / 89$ & OGJ & $126 \mathrm{MMbb} / \mathrm{s}$ added, $1.449 \mathrm{Bbbls}$ total \\
\hline 'Mldgard & Saga & 1981 & $1 / 90$ & Pet Engr & 3.4 Tct \& 100 MMbbls cond Haltenbanken area \\
\hline Froy Satellite & Elf & 1989 & $2 / 90$ & OQJ & 30.60 MMbbls North of Froy structure \\
\hline $3 / 7 / 04$ & Shell & 1990 & $2 / 90$ & OQJ & 40-50 MMbbis \& $300-400$ Bct Sojne basin \\
\hline Tordis & Saga & & $5 / 90$ & ठक्र & 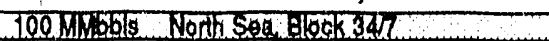 \\
\hline
\end{tabular}

Oman

$\begin{array}{llllll}\text { 'Bukha } & \text { IPC } & 1979 & 10 / 87 & \text { AAPG } & 40 \text { MMbbls } \\ \text { 'Saiah } & \text { Occidental } & 1983 & 4 / 89 & \text { Com Rpt } & 50 \text { MMbbls increasa } 1 / 21.71 \text { MMbbls due lo development drilling } \\ \text { Saih Nihayda (deep) } & \text { PDO } & 1989 & 6 / 89 & \text { Oll Dly } & 353 \text { Bdt } \\ \text { 'Salh Nihayda (sliallow) } & \text { PDO } & 1972 & 6 / 89 & \text { Oil Dly } & 1.2 \text { Tct }\end{array}$

Papua New Guinea

\begin{tabular}{|c|c|c|c|c|c|}
\hline \multirow[t]{3}{*}{ •Juha } & Niugini Gulf & 1982 & $8 / 87$ & W. Oll & 65 MMbbls \& $1 \mathrm{Tcl}$ Suspended Development \\
\hline & & & $2 / 88$ & Pet News & $32 \mathrm{MMbb} / \mathrm{s} \& .8 \mathrm{Tct}$ \\
\hline & & & $3 / 89$ & OGJ & $90 \mathrm{MMbb} / \mathrm{s} \& 1.1 \mathrm{Tct}$ \\
\hline \multirow[t]{3}{*}{ "lagifu } & Niugini Gulf & 1985 & $8 / 87$ & W. Oil & $500 \mathrm{MMbbls}$ Southern Highlands \\
\hline & & & $2 / 88$ & Pet News & $500 \mathrm{MMbbls}$ \\
\hline & & & $10 / 88$ & AAPG & $400 \mathrm{MMbbls} 46 \mathrm{API}$ \\
\hline \multirow[t]{5}{*}{ "Hides \#1 } & BF Dev & 1987 & $1 / 88$ & OGJ & 1.5 Tof 27.97 MMcld \& $447 \mathrm{bbl} / \mathrm{d} 2$ zones Southern Highlands \\
\hline & & & $2 / 88$ & Pet News & $1.5 \mathrm{Tct}$ \\
\hline & & & $3 / 89$ & OG.J & 2 Tct \& $60 \mathrm{MMbbls}$ cond \\
\hline & & & $9 / 89$ & Pel News & $1.5 \mathrm{Tc} \& 39 \mathrm{MMbbls}$ cond Southern Highlands \\
\hline & & & 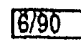 & Pellnows & $2 \mathrm{TCl}$ \\
\hline \multirow[t]{3}{*}{ 'Pasca A } & Kelvin Energy & 1968 & $2 / 88$ & Pet News & 30 MMbbls \& $300-410 \mathrm{Bct}$ \\
\hline & & & $2 / 89$ & Pet news & 36 MMbbls \& $300 \mathrm{Bct}$ \\
\hline & & & $9 / 89$ & Pet News & $36 \mathrm{MMbbls} \& 350 \mathrm{Bct}$ offshore \\
\hline \multirow[t]{2}{*}{-Pandora } & IPC & 1988 & $12 / 88$ & OGJ & 3 Tct oftshore \\
\hline & & & $9 / 89$ & Pot Nows & 4 Tol proved, 1.7 Tef probable, 2.7 Tof possible offshore \\
\hline "lagifu \& NW Hedinia & & & $12 / 88$ & Pot Nows & $130 \mathrm{MMbbls}$ \\
\hline \multirow[t]{2}{*}{ 'lagifu Hedinia-SE Hedinia } & Chevron Niugini Gulf & & $2 / 89$ & Pet News & $115.500 \mathrm{MMbb} / \mathrm{s}$ \\
\hline & & & $8 / 89$ & W. Oil & 230 MMbbls \\
\hline "lagifu \& Hedinia & Chevron & & $3 / 89$ & OGJ & $30-300 \mathrm{MMbb} / \mathrm{s}$ \\
\hline 'Agogo & Chevron & 1989 & $8 / 89$ & W. Oil & 50 MMbbls on trend with lagitu and Hedinla \\
\hline Thaifu, Hedina, Agogo & Chevren & & $5 / 90$ & OG & $1701 \times 1656$ \\
\hline
\end{tabular}

Peru

\begin{tabular}{|c|c|c|c|c|c|}
\hline 'Cashiriari & Shell & 1986 & $10 / 87$ & AAPG & $4 \mathrm{Td}$ \\
\hline \multirow[t]{2}{*}{ 'San Martin } & Shell & 1984 & $10 / 87$ & AAPG & $3 \mathrm{Tcl}$ \\
\hline & & & $2 / 88$ & AAPG & 1.8 Bbbls $\theta q$ \\
\hline \multirow[t]{3}{*}{ 'San Martin'Cashirian' } & Shell & & $3 / 88$ & OGJ & $12 \mathrm{Tct} \& 650 \mathrm{MMbb} / \mathrm{s}$ \\
\hline & & & $8 / 88$ & W. Oil & $10 \mathrm{Tcl} \& 600 \mathrm{MMbbls}$ cond \\
\hline & & & $8 / 89$ & OGJ & $10 \mathrm{Tcl} \& 750 \mathrm{MM}$ sbls a.h.a. Camisea south central jungle \\
\hline 'Chambira $123 \mathrm{X}$ & Petroperu & 1989 & $8 / 89$ & OGJ & 30.50 MMbbls 26 API northern jungle \\
\hline
\end{tabular}

See lootnotes al and of table. 
Table A1. Foreign Oll and Gas Reserve Discoveries (Continued)

\begin{tabular}{llllll}
\hline Country/Field/Well & Company & $\begin{array}{l}\text { Disc } \\
\text { Date }\end{array}$ & $\begin{array}{l}\text { Report } \\
\text { Date }\end{array}$ & Source & Reserves and \\
\hline Phillippines & & & & & \\
& & & & & \\
'Matinloc & Alcorn & 1978 & $7 / 89$ & OGJ & $1.45 \mathrm{MMbb} / \mathrm{s}$ \\
'North Matinloc & Alcorn & 1989 & $7 / 89$ & OGJ & $4.157 \mathrm{MMbbls}$ \\
'Galoc & Alcorn & 1981 & $7 / 89$ & OGJ & $40.50 \mathrm{MMbbls}$ \\
'Nido & Alcorn & 1976 & $7 / 89$ & OGJ & $0.735 \mathrm{MMbb} / \mathrm{s}$ \\
'Cadlao & Alcorn & 1977 & $7 / 89$ & OGJ & $11.2 \mathrm{MMbbls}$
\end{tabular}

Qatar

'North Fiele

QGPC

$\begin{array}{llll}1971 & 8 / 87 & \text { W. Oll } & 130 \text { Tct } \\ & 5 / 89 & \text { OQJ } & 150 \text { Tct }\end{array}$

Romanla

'E. \& W. Lebada

W. OAl

73 MMbbls Black Ser

Sáudl Arabla

-Centrai Provinco

Saudi Aramco

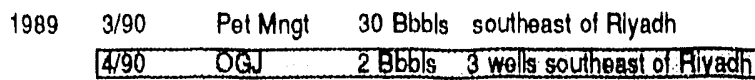

South Atrica

iMossel Bay Area

Soekor

$8 / 87$

W. Oll $\quad 1$ Tet

Sudan

'Suakin

W. Oil

123 MMbbls \& 864 Bct Red Sea $30 \mathrm{ml}$ from Port Sudan

Sweden

Klints Bank

Satellite Explor

$1989 \quad 4 / 89 \quad$ OGJ

63 MMbbls Swodish Battic Sea ofl NE Gotland

Talwan

$\cdot \mathrm{BKK}$

CPC

$1979 \quad 1 / 87$

Pel News 5.10 MMbbls \& 108 Bd

$2 / 88$ Pet News 5-10 MMbbls Strails of Talwan

Thalland

Total CFP

"Kaphong

"Nam Phong

Unocal

Esso

Shell

$\begin{array}{ll}1973 & 7 / 8 \\ & 10 \\ & 12 \\ & 1 / 90 \\ & \\ 1979 & 7 / 88 \\ 1982 & 12 / 88 \\ 1981 & 2 / 89\end{array}$

\begin{tabular}{l}
$7 / 88$ \\
$10 / 89$ \\
$12 / 89$ \\
$1 / 90$ \\
1490 \\
\hline $7 / 88$ \\
$12 / 88$ \\
$2 / 89$
\end{tabular}

OGJ $\quad 1.8 \mathrm{Tct}, 6 \mathrm{Tet}$ possible

Pol Nows 3.5 Tct

OGJ $\quad 1.8 \mathrm{Tcl} \& 32 \mathrm{MMbbls}$ cond

OGJ $3.5 \mathrm{Tel}$ Gulf of Thalland

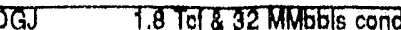

OGJ 376 Bct \& $8.699 \mathrm{MMbbls}$

OGJ 1.5 Tct Kaen Province $310 \mathrm{mI} \mathrm{NE}$ of Bangkok $100 \mathrm{ppm} \mathrm{H} 2 \mathrm{~S}$

OGJ $2.0 \mathrm{MMbbls}$, a $40 \%$ increase $1070 \mathrm{MMbbls}$

\footnotetext{
See tootnotes at end of table
} 
Table A1. Foreign Oll and Gas Reserve Discoverles (Continued)

\begin{tabular}{lllll}
\hline Country/Field/Well & Company & $\begin{array}{l}\text { Disc } \\
\text { Date }\end{array}$ & $\begin{array}{l}\text { Report } \\
\text { Date }\end{array}$ & Source Reserves and Comments \\
\hline 'E.5 Structure & Esso & $1981 \quad 10 / 89 \quad$ Pot Nows 1.5 Tof located in Khon Kaen
\end{tabular}

Trinidad \& Tobago

$\begin{array}{lllll}\text { •Pellcan } & 1977 \quad 8 / 89 & \text { W. Oll } 21 \text { MMbbls \& } 740 \text { Bof }\end{array}$

Tunisia

WIEkar Britsh Gas 1975 6/90 09 TाC offirat

Turkey

"Karakus

'Zeynel \#1

"Nomnt "1

United Kingdom

-Amethyst East \& West

BP

$\mathrm{BP}$

- Forties

-Magnus

Nolson

-Gryphon

Forth

- PickereWalkụie area

'N \& S Welland

"Venture

- Lancelot area

- Anglia

- Camelot

"North Ravenspurn

Sole Pits area

'Gannet Group

- Joanne \& Judy

'Tittany \& Toni
TPAO

Alladin Middle East

Alladin Middle East

$\begin{array}{lll}1988 & 12 / 89 & \text { OQJ } \\ 1989 & 2 / 90 & \text { JPT }\end{array}$

$\begin{array}{lll}1989 & 2 / 90 & \text { JPT } \\ 1990 & 2 / 90 & \text { JPT }\end{array}$
112 MMbbls near Kahta

10 MMbbls SE Turkey

$25 \mathrm{MMbb} / \mathrm{s}$ SE Turkey

\begin{tabular}{|c|c|c|c|}
\hline \multirow[t]{2}{*}{1977} & $4 / 87$ & P. Times & $50 \mathrm{MMbb} / \mathrm{s}$ \\
\hline & $8 / 88$ & Pel Engr & $56 \mathrm{MMbb} / \mathrm{s}$ \\
\hline \multirow[t]{3}{*}{1972} & $4 / 87$ & P. Times & $283 \mathrm{Bcf}$ \\
\hline & $8 / 88$ & OQJ & $850 \mathrm{Bcf}$ \\
\hline & $4 / 89$ & W. Oll & 850 Bof \& 9 MMbbls cond \\
\hline 1970 & $8 / 87$ & W. OII & 319 MMbbls Upward Rovision \\
\hline 1974 & $8 / 87$ & W. Oll & $100 \mathrm{MMbb} / \mathrm{s}$ Upward Revision \\
\hline \multirow[t]{2}{*}{1987} & $3 / 88$ & OQJ & $150.175 \mathrm{MMbbls} 6500 \mathrm{bbVd} 40 \mathrm{API}$ \\
\hline & $4 / 89$ & W. OIl & $320 \mathrm{MMbb} / \mathrm{s}$ \\
\hline
\end{tabular}

Enterprise/Shell

W. OI

OGJ $\quad 350 \mathrm{MMbb} / \mathrm{s} \& 100 \mathrm{Bcf}$

$\mathrm{Ker} \cdot \mathrm{McG}_{\theta \theta}$

1987

Pet Mngt

Pet Engr $\quad 300.700 \mathrm{MMbb} / \mathrm{s}$

W. 에 $\quad 175-250$ MMbbls

AAPG $250 \mathrm{MMbbis}$ Block 9/18b

OGJ $250 \mathrm{MMbb} / \mathrm{s}$

Pet Mngt $200 \mathrm{MMbb} / \mathrm{s} \& 60 \mathrm{Bct}$

OGJ $200 \mathrm{MMbb} / \mathrm{s} \& 600 \mathrm{Bct}$

OGJ $850 \mathrm{BCf}$

OGJ 75 Bct Pickerill only

OQJ $\quad 300 \mathrm{Bct}$

OQJ $60 \mathrm{Bct}$

OGJ $600 \mathrm{Bct}$

OLJ $250 \mathrm{BCt}$

OGJ 2.00 Bct Blocks 48/18b \& 48/19b North Sea

OGJ $250 \mathrm{Bct}$

Com Rpt 210 Bct

OQJ $250 \mathrm{Bct}$

OGJ $\quad 1.3 \mathrm{Tcf}$ reserves 2 Tct in place

W. OIl $1.2 \mathrm{Tcf}$

OGJ $3 \mathrm{TCl}$

OGJ $500 \mathrm{Bc}$

Pel Engr 170 Mimbbls \& 700 Bd 112 mi east of Aberdeon

$19818 / 88$ OGJ 400 Bct \& $150 \mathrm{MMbbls}$

$6 / 90$ PelMngt 600 Bo \& 150 MMEb/s JElock

1977 8/88 OGJ 125 Bct \& 180 MMbbls T-block 16/17

See tootnotes at end of table. 
Table A1. Forelgn OIl and Gas Reserve Discoveries (Continued)

\begin{tabular}{|c|c|c|c|c|c|}
\hline Country/Fleld/Well & Company & $\begin{array}{l}\text { Disc } \\
\text { Date }\end{array}$ & $\begin{array}{l}\text { Report } \\
\text { Date }\end{array}$ & Source & Reserves and Comments \\
\hline -Abroath & Amoco & $12 / 69$ & $8 / 88$ & Pol Engr & 103 MMbbls $5 \mathrm{ml}$ tMontrose field \\
\hline \multirow[t]{4}{*}{ "Miller } & $\mathrm{BP}$ & 1983 & $8 / 88$ & Pol Engr & 300 MNbbls blocks $16 / 7$ \& $16 / 8$ \\
\hline & & & $10 / 88$ & OGJ & 300 MMbbls \& 570 Bct \\
\hline & & & $4 / 89$ & W. 에 & $326 \mathrm{MMbb} / \mathrm{s} \& 470 \mathrm{Bcf}$ \\
\hline & & & $7 / 89$ & OGJ & 300 MMbbls \& 570 Bct of sour gas \\
\hline "Kittiwake & Shell Expro & 1981 & $8 / 88$ & Pet Engr & $70 \mathrm{mMbb} / \mathrm{s}$ block $21 / 18$ \\
\hline \multirow[t]{4}{*}{ 'Scolt (Waverley/Brunel) } & Amerada Hess & 1984 & $8 / 88$ & Pet Engr & 160.200 MMbble blocks $15 / 21$ a \& $15 / 22$ \\
\hline & & & $10 / 88$ & OGJ & 250 MMbbls combined Waverley \& Brunel \\
\hline & & & $12 / 88$ & OGJ & $400 \mathrm{MMbbls}$ comblnod Waverley \& Brunel \\
\hline & & & 690 & Com Bol. & 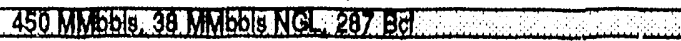 \\
\hline $16 / 28 c \cdot 11$ & $\mathrm{BP}$ & 1988 & $9 / 88$ & OQJ & $10 \mathrm{MMbbls} 6000 \mathrm{bbl} / \mathrm{d}$ 1st honzontal well $1 / \mathrm{seml}$ off U.K. \\
\hline "Hudson Field 210/24a & Amoco & 1987 & $10 / 88$ & AAPG & $100 \mathrm{MMbb} / \mathrm{s}$ \\
\hline 'Crawtord 9/28 & Hamltton Bros & 1975 & $10 / 88$ & OGJ & $14.6 \mathrm{MMbbls} 140 \mathrm{ml}$ east of Orkney Islands \\
\hline 'Osprey & Shell & 1974 & $12 / 88$ & OQJ & $60 \mathrm{MMbb} / \mathrm{s}$ \\
\hline 'Wytch Farm ottshore & $\mathrm{BP}$ & 1988 & $12 / 88$ & OGJ & $100 \mathrm{MMbbis}$ oftshore extension to Wytoh Farm fletd \\
\hline \multirow[t]{2}{*}{ - Clipper \& Barque flelds } & Shell & 1971 & $12 / 88$ & Com Rpt & 860 Bof Sole Pit area southem North Sea \\
\hline & & & 4/89 & W. OII & $874 \mathrm{Bct}$ \\
\hline \multirow[t]{2}{*}{ 'Emerald } & Soverelgn & 1978 & $2 / 89$ & OGJ & $43 \mathrm{MMbbls} 24 \mathrm{API} \quad 1 / 5150.5600 \mathrm{ft} \quad 70 \mathrm{ml}$ E of Shetlands \\
\hline & & & $8 / 89$ & OGJ & $40 \mathrm{MMbbls}$ \\
\hline 'Claymore & Occidental & 1974 & $2 / 89$ & OGJ & 46 MMbbls, a $31 \%$ increase to $195 \mathrm{MMbb} / \mathrm{s}$ total remalning \\
\hline 'Chanter & Occidental & 1985 & $4 / 89$ & W. Oll & 9 MMbbls \& 29 Bof \\
\hline \multirow[t]{3}{*}{ ‘cyrus } & $\mathrm{BP}$ & 1979 & $4 / 89$ & W. Oil & $15 \mathrm{MMbbls}$ \\
\hline & & & $8 / 89$ & OQJ & $11.4 \mathrm{MMbbis}$ \\
\hline & & & $10 / 89$ & OGJ & $13 \mathrm{MMbb} / \mathrm{s}$ \\
\hline \multirow[t]{2}{*}{ ‘Glamis/Blair } & Sun & 1982 & $4 / 89$ & W: Oll & $18 \mathrm{MMbb} / \mathrm{s}$ \\
\hline & & & $8 / 89$ & OGJ & $17.5 \mathrm{MMbb} / \mathrm{s}$ \\
\hline \multirow[t]{2}{*}{ "Ivanhoe/Rob Roy } & Amerada Hess & 1975 & $4 / 89$ & W. 에 & 88 MMbbls \& 30 Bot \\
\hline & & & $5 / 89$ & OGJ & $105 \mathrm{MMbbls} \& 65$ Bet Block 15/21a, $110 \mathrm{ml}$ east of Aberdeen \\
\hline ·Tern & Shell & 1975 & $4 / 89$ & W. Oli & $175 \mathrm{MMbbls}$ \\
\hline \multirow[t]{2}{*}{ "Wyich Farm } & $\mathrm{BP}$ & 1974 & $7 / 89$ & OGJ & $230 \mathrm{MMbb} / \mathrm{s}$ \\
\hline & & & $2 / 90$ & OQJ & $300 \mathrm{MMbbls}$ on and offshore \\
\hline \multirow[t]{2}{*}{ 'Bruce } & $\mathrm{BP}$ & 1974 & $8 / 89$ & OQJ & $2.5 \mathrm{Tct} \& 210 \mathrm{MMbb} / \mathrm{s}$ \\
\hline & & & $9 / 89$ & OGJ & $2.6 \mathrm{Tcl} \& 210 \mathrm{MMbbls}$ cond \& NGL Blocks $9 / 8 \mathrm{a}, 9 / 9 \mathrm{a}, 9 / 9 \mathrm{~b}$ \\
\hline - East Braa & Marathon & 1980 & $8 / 89$ & OGJ & $300 \mathrm{MMbbls} \& 1.2 \mathrm{Tcf}$ \\
\hline \multirow[t]{3}{*}{ 'Alba } & Chevron & $8 / 84$ & $8 / 89$ & OQJ & $320 \mathrm{MMbb} / \mathrm{s}$ \\
\hline & & & $11 / 89$ & OQJ & 250 MMbbls 20 API 1 Bbbls In place Block $16 / 26$ \\
\hline & & & 490 & OGJ & 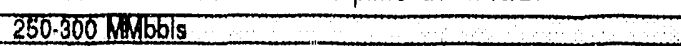 \\
\hline 'Block 4/26 & Ranger & 1985 & $8 / 89$ & OQJ & $150 \mathrm{Act}$ \\
\hline Franklin & Ultramar & 1986 & $8 / 89$ & OGJ & 2 Tot \& 200 MMbbls Block 29/5 North Sea \\
\hline - Eidar & & 1976 & $8 / 89$ & W. Oil & $88 \mathrm{MMbbls}$ \\
\hline 'Alwy" North & & 1975 & $8 / 89$ & W. Oil & 950 Bct \\
\hline "Audrey & & 1976 & $8 / 89$ & W. Oil & $1 \mathrm{Tct}$ \\
\hline 'Cleoton \& S Ravenspurn & & 1983 & $8 / 89$ & W. Oll & $1.2 \mathrm{Tct}$ \\
\hline 'Wellon & & 1982 & $8 / 89$ & W. Oil & $20 \mathrm{MMbb} / \mathrm{s}$ \\
\hline \multirow[t]{3}{*}{ •Saltire (East Piper) } & Occidental & 1988 & $8 / 89$ & Pot Engr & $60 \mathrm{MMbb} / \mathrm{s}$ \\
\hline & & & $8 / 89$ & Com Rpt & 100 MMbbls Block $15 / 17$ \\
\hline & & & $6 / 90$ & Com Hol & $130 \mathrm{MT}$ b5/s \\
\hline 'Molra & Phillips & 1988 & $9 / 89$ & OQJ & 5.5 MMbbis Block $16 / 29 \mathrm{a}$ \\
\hline 'Linnhe & Mobil & 1988 & $9 / 89$ & OQJ & $10 \mathrm{MMbb} / \mathrm{s}$ \\
\hline "Block 15/20a & $\mathrm{BP}$ & 1987 & $10 / 89$ & OGJ & $21 \mathrm{MMbbls} 160 \mathrm{mi}$ NE of Aberdeen \\
\hline 'Thistle & $\mathrm{BP}$ & 1973 & $11 / 89$ & OQJ & $57 \mathrm{MMbbls}$ added, $420 \mathrm{MMbbls}$ total \\
\hline 'Beatrice & $\mathrm{BP}$ & 1976 & $11 / 89$ & OGJ & $18 \mathrm{MMbbls}$ added, $130 \mathrm{MMbb} / \mathrm{s}$ total \\
\hline Ninian & Chevron & 1974 & $1 / 90$ & OQJ & $55.155 \mathrm{MMbbl}$ increase to $1.1-1.2 \mathrm{Bbbls} 100 \mathrm{ml} \mathrm{E}$ of Shetland is \\
\hline 'Hamish & Amerda Hess & 1988 & $2 / 90$ & OQJ & 1.5 MMbbls Biock $15 / 2.1 \mathrm{~b}$ closa to Rob Roy \\
\hline Wareham & $\mathrm{BP}$ & 1964 & $2 / 90$ & OGJ & 6 Misbbls close to Wytch Farm \\
\hline Murdoch & Conoco & 1964 & E) & ठGJ & 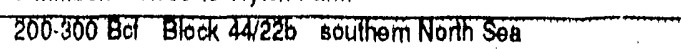 \\
\hline -Andrews & & 1974 & $6 / 90$ & Pot Mngl & 75 MMbbls \& 150 Bat Nenth 89 \\
\hline
\end{tabular}

See tootnotes at end of table. 
Table A1. Foreign Oll and Gas Reserve Discoveries (Continued)

\begin{tabular}{|c|c|c|c|c|c|}
\hline Couniry/Fleld/Well & Cnmpany & $\begin{array}{l}\text { Disc } \\
\text { Date }\end{array}$ & $\begin{array}{l}\text { Repori } \\
\text { Date }\end{array}$ & Source & Reserves and Comments \\
\hline \multicolumn{6}{|l|}{ USSR } \\
\hline 'Bovanenko/Kharasavey & & 1971 & $8 / 87$ & W. OII & 190 Tet Yamal Peninsula \\
\hline \multirow[t]{6}{*}{ Tenglz } & & 1979 & $4 / 88$ & OGJ & 18.25 Bbbls oil in place NE Caspian basin \\
\hline & & & $4 / 88$ & PIW & 14-19 Bbbls oll in placo \\
\hline & & & $8 / 88$ & W. Oll & 18.25 Bbbls ofl in place North Casplan basin \\
\hline & & & 4/89 & OGJ & 6.7 Bbbls $16 \mathrm{Bbb} / \mathrm{s}$ oil in place \\
\hline & & & $8 / 89$ & W. 에 & 9.5 Bbbls officlally reported Soviet reserves \\
\hline & & & 690 & OG & 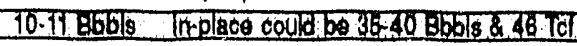 \\
\hline \multirow[t]{2}{*}{ 'Bovanenkovskoye } & & 1971 & $8 / 88$ & W. OII & 79 Tof Yamal Poninsula \\
\hline & & & $2 / 89$ & OGJ & 146 Tet Yamal Peninsula \\
\hline "Komsomolskoye & & 1966 & $2 / 89$ & OQJ & 16 Tof western Slberia proved \& probable \\
\hline "Yubllelnoye & & 1969 & $3 / 89$ & OQJ & 12.1 Tof westem Siberia proved \& probable \\
\hline Peltunastokskoye & & & $4 / 89$ & OGJ & 200 MMbbls off Sakhalln Island Soa of Okhotsk \\
\hline \multirow[t]{3}{*}{ Shtokmanovskoye } & & 1988 & $9 / 89$ & OQJ & 105-141 Tof Barents Sea \\
\hline & & & $1 / 90$ & OG.J & 106 Tof Barents Sea $250 \mathrm{mi}$ NE of Murmansk \\
\hline & & & 6960 & OGI & गयाल \\
\hline Russanovskoye & & 1989 & $12 / 89$ & AAPG & 210 Tet Kara Sea \\
\hline Husgkoye & & $\sqrt{968}$ & $6 / 90$ & ठब & 5. IC northem tyumen province \\
\hline
\end{tabular}

Veriezuela

\begin{tabular}{|c|c|c|c|c|c|}
\hline ORS. 52 & Lagoven & $1 / 86$ & $11 / 86$ & AAPG & 70 MMbbls \& $870 \mathrm{Bcf}$ \\
\hline \multirow[t]{3}{*}{ Orinoco Heavy Oil Belt } & & & $11 / 86$ & AAPG & $267 \mathrm{Bbbls}$ \\
\hline & & & $8 / 87$ & W. Oil & $18.200 \mathrm{Bbb} / \mathrm{s}$ \\
\hline & & & $7 / 89$ & OGJ & 500 Bbbls 1.25 Tbbls in place \\
\hline \multirow[t]{6}{*}{ 'El Furrial } & Lagoven & $12 / 85$ & $11 / 86$ & AAPG & 1.07 Bbbls \& $3.7 \mathrm{Tct}$ \\
\hline & & 1986 & $8 / 87$ & W. OII & $528 \mathrm{MMbb} / \mathrm{s}$ Monagas State \\
\hline & & 1986 & $10 / 87$ & AAPG & $.5-1$ Bbbls Monagas Stalo \\
\hline & & 1986 & $2 / 88$ & AAPG & 2 Bbbls \& 2.8 Tct Monagas State \\
\hline & & & $6 / 88$ & OGJ & $832 \mathrm{MMbb}$ bls Monagas Stato \\
\hline & & & $8 / 89$ & W. OII & $307 \mathrm{MMbb} / \mathrm{s} \& 542 \mathrm{Bcf}$ \\
\hline S. Lakø Maracaibo & Lagoven & 1986 & $8 / 87$ & W. OII & 200 MMbbls S. Lake Maracalbo \\
\hline Apure Area & Conpoven & 1986 & $8 / 87$ & W. Oil & 600.700 MMbbls Apure Area \\
\hline \multirow[t]{2}{*}{ Eastern Venezuela Basin } & & & $2 / 88$ & AAPG & $500 \mathrm{Bbbls}$ \\
\hline & & & $3 / 88$ & OGJ & $11.3 \mathrm{Bbb} / \mathrm{s}$ \\
\hline Monagas El Furrial Fields & & & $3 / 88$ & OGJ & 8.6 Bbbls Monagas State Only \\
\hline "Ceuta V/LG $3725 X$ & Maraven & & $8 / 88$ & W. Oil & $140 \mathrm{MMbb} / \mathrm{s}$ \\
\hline 'El Carito \#1X & Corpoven & 1988 & $8 / 88$ & W. Oil & 1.2 Bbbls \& $2.8 \mathrm{Tct} 8000 \mathrm{bbldd} 35 \mathrm{API}$ \\
\hline west Lake Naracalbo & PDVSA & $7 / 87$ & $8 / 88$ & W. OII & $819 \mathrm{MMbb}$ ls western Lake Maracalbo region new fleld \\
\hline El Furrial Norte $\# 1$ & Lagoven & 1988 & $9 / 88$ & OGJ & $150 \mathrm{MMbbls} 7057 \mathrm{bbV} / \mathrm{d} 23.5 \mathrm{API}$ TVD $16420 \mathrm{ft}$ \\
\hline 'Ceuta South-Southeast & Maraven & 1985 & $9 / 88$ & AAPG & $800 \mathrm{MMbb} / \mathrm{s}$ south of Lake Maracalbo \\
\hline "Musipan & & 1987 & $8 / 89$ & W. Oil & $520 \mathrm{MMbb} / \mathrm{s}$ Monagas State \\
\hline 'Guafita & & 1984 & $8 / 89$ & W. Oil & $450 \mathrm{MMbb} / \mathrm{s}$ Apure State \\
\hline 'Boqueron & Lagoven & 1989 & $8 / 89$ & Oil Dly & $380 \mathrm{MMbb} / \mathrm{s}$ Monagas State \\
\hline
\end{tabular}

Vietnam

\begin{tabular}{|c|c|c|c|c|c|}
\hline 'White Tiger (Bach Ho) & VielSovpetro & 1970 & $\begin{array}{l}2 / 89 \\
2 / 89\end{array}$ & $\begin{array}{l}\text { Pet News } \\
\text { AAPG }\end{array}$ & $\begin{array}{l}2.1 \text { Bbbls offshore Ho Chi Minh City } \\
20 \text { MMbbls } 50-100 \text { MMbbls possible }\end{array}$ \\
\hline & & & $10 / 89$ & Pet News & 80.100 MMbbls \\
\hline${ }^{\circ} \mathrm{G}$ & Petrovietnam & 1988 & $2 / 89$ & Pet News & $\operatorname{linh} C$ \\
\hline
\end{tabular}

\footnotetext{
Seo footnoles at and of table.
} 
Table A1. Foreign Oll and Gas Reserve Discoverles (Continued)

\begin{tabular}{|c|c|c|c|c|c|}
\hline Country/Fleld/Well & Company & $\begin{array}{l}\text { Disc } \\
\text { Date }\end{array}$ & $\begin{array}{l}\text { Report } \\
\text { Date }\end{array}$ & Source & Reserves and Comments \\
\hline \multicolumn{6}{|l|}{ West Germany } \\
\hline "Mittelplate & Texaco/Wintershall & 1980 & $8 / 87$ & W. O에 & 115 MMbbls Heawy OIl \\
\hline$B / 4$ & BEB & 1988 & $4 / 89$ & W. Oil & $50 \mathrm{Bct}$ oftshore \\
\hline \multicolumn{6}{|l|}{ Yemen } \\
\hline •Alif & Yemen Hunt Oll & 7/84 & $8 / 87$ & W. O에 & 500 MMbbls Martb \\
\hline -Wadi al Jawt Area & Yepco & 1986 & $8 / 87$ & W. 에 & 500 MMbbls \& 6 Tct In Addition to Allf \\
\hline 'Asa'ad Al-Kamil & YEPCO & $12 / 87$ & $8 / 89$ & OGJ & 2.7 Tct \& 133 MMbbls \\
\hline
\end{tabular}

- Field is also in Petroconsultants data base which does not necessarily have the same reserve value.

Sources: AAPG: 'American Assoclation of F'etroleum Gjologists Bulletin or Explorer. Com Rpt: Company Report elther annual or quarterty stock holders reports. JPT: Journal al Petroleum Technology. Oen Ind: Ocean Industries. OGJ: Oll and Gas Joumal. OH Dhy: The Oil Daily. PIW: Petroleum Inteligence Wookly. P. Times: Petroloum Times. Pot Engr: Petroleum Engineor Intemational. Pot Mngt: Petroleum Management. Pat Nows: Petroloum News. W. On: World Oil. 
Appendix B

Modified

Petroconsultants

Reserve Additions 


\section{Appendix B}

Table B1. Modifled Petroconsultants Reserve Additions

\begin{tabular}{|c|c|c|c|c|c|c|}
\hline \multirow[b]{2}{*}{ Country } & \multicolumn{3}{|c|}{ Oll, MMbbis } & \multicolumn{3}{|c|}{ Natural Gas, Bcf } \\
\hline & $\begin{array}{c}\text { Last } 3 \\
\text { Months } \\
4 / 90-6 / 90\end{array}$ & $\begin{array}{c}\text { Last } 12 \\
\text { Months } \\
7 / 89-6 / 90\end{array}$ & $\begin{array}{c}\text { Last } 36 \\
\text { Months } \\
7 / 87-6 / 90\end{array}$ & $\begin{array}{c}\text { Last } 3 \\
\text { Months } \\
4 / 90-6 / 90\end{array}$ & $\begin{array}{c}\text { Last } 12 \\
\text { Months } \\
7 / 89-6 / 90\end{array}$ & $\begin{array}{c}\text { Last } 36 \\
\text { Months } \\
7 / 87-6 / 90\end{array}$ \\
\hline \multicolumn{7}{|l|}{ North America } \\
\hline Cuba & 0 & 59 & 60 & 0 & 139 & 139 \\
\hline Guatemala & 0 & -8 & 21 & 0 & -4 & -4 \\
\hline Mexico & 0 & 840 & 19,225 & 0 & 3,899 & 24,229 \\
\hline Total & 0 & 891 & 19,306 & 0 & 4,034 & 24,364 \\
\hline \multicolumn{7}{|l|}{ South America } \\
\hline Argentina & 141 & 339 & 3,009 & 410 & $-3,479$ & 25,117 \\
\hline Barbados & 0 & -2 & -3 & 0 & -3 & 8 \\
\hline Bolivia & 1 & 2 & 41 & 0 & 245 & 562 \\
\hline Brazil & 410 & 1,954 & 5,074 & 290 & 1,368 & 5,175 \\
\hline Chile & 0 & 24 & 168 & 0 & 99 & 7,274 \\
\hline Colombia & 50 & 513 & 1,285 & 1,248 & 1,700 & 2,192 \\
\hline Ecuador & 23 & 52 & 492 & 37 & 179 & -284 \\
\hline Peru & 0 & 32 & 20 & 0 & 0 & 11,636 \\
\hline Suriname & 0 & 0 & 9 & 0 & 0 & 0 \\
\hline Trinidad & 45 & 135 & 273 & 300 & 102 & 332 \\
\hline Venezuela & 196 & -146 & 20,165 & 3,242 & 5,802 & 16,352 \\
\hline Total & 866 & 2,903 & 30,533 & 5,527 & 6,013 & 68,364 \\
\hline \multicolumn{7}{|l|}{ Western Europe } \\
\hline Austria & 5 & 2 & 29 & -4 & 75 & 350 \\
\hline Denmark & 32 & 76 & 357 & 123 & 241 & 118 \\
\hline France & -3 & 14 & 139 & 0 & 498 & 2,333 \\
\hline Greece & 0 & 0 & -46 & 0 & 0 & -15 \\
\hline Ireland & 1 & 1 & 11 & 2 & 302 & 349 \\
\hline Italy & -32 & -24 & 163 & 298 & 2,998 & 2,047 \\
\hline Netherlands & 10 & 4 & 156 & 1,953 & 4,985 & 4,711 \\
\hline Norway & -319 & 876 & 3,197 & 660 & 5,012 & 5,112 \\
\hline Spain & 0 & -8 & 12 & 0 & -40 & -18 \\
\hline Svalbard & 0 & 0 & 0 & 500 & 500 & 500 \\
\hline Sweden & 0 & 0 & 1 & 0 & 0 & 0 \\
\hline Switzerland & 0 & 0 & 0 & 0 & 0 & 4 \\
\hline United Kingdom & -208 & 47 & 033 & 1,033 & 1,245 & 14,534 \\
\hline West Germany & 70 & 71 & 268 & -847 & -4 & $-1,342$ \\
\hline Total & -444 & 1,059 & 8,320 & 3,718 & 15,812 & 28,683 \\
\hline \multicolumn{7}{|l|}{ Eastern Europe } \\
\hline Bulgaria & 0 & 0 & 0 & 0 & 0 & -350 \\
\hline Poland & 0 & 0 & 0 & 0 & 25 & 27 \\
\hline Romania & 0 & 75 & 213 & 0 & 0 & 282 \\
\hline U.S.S.R. & 0 & 4,735 & 8,655 & 0 & $-47,513$ & 13,847 \\
\hline Yugoslavia & 0 & 53 & 764 & 45 & 873 & 3,272 \\
\hline Total & 0 & 4,863 & 9,632 & 45 & $-46,615$ & 17,078 \\
\hline
\end{tabular}

See footnotes at end of table. 
Table B1. Modified Petroconsultants Reserve Additions (Continued)

\begin{tabular}{|c|c|c|c|c|c|c|}
\hline \multirow[b]{2}{*}{ Country } & \multicolumn{3}{|c|}{ Oil, MMbbls } & \multicolumn{3}{|c|}{ Natural Gas, Bcf } \\
\hline & $\begin{array}{c}\text { Last } 3 \\
\text { Months } \\
4 / 90-6 / 90 \\
\end{array}$ & $\begin{array}{c}\text { Last } 12 \\
\text { Months } \\
7 / 89-6 / 90\end{array}$ & $\begin{array}{c}\text { Last } 36 \\
\text { Months } \\
7 / 87-6 / 90 \\
\end{array}$ & $\begin{array}{c}\text { Last } 3 \\
\text { Months } \\
4 / 90-6 / 90\end{array}$ & $\begin{array}{c}\text { Last } 12 \\
\text { Months } \\
7 / 89-6 / 90\end{array}$ & $\begin{array}{c}\text { Last } 36 \\
\text { Months } \\
7 / 87-6 / 90\end{array}$ \\
\hline \multicolumn{7}{|l|}{ Middle East } \\
\hline Abu Dhabi & 0 & 594 & 27,879 & 190 & 2,150 & 33,965 \\
\hline Bahrain & 0 & 0 & -50 & 0 & 500 & 2,000 \\
\hline Dubai & 0 & 70 & 70 & 0 & 0 & 250 \\
\hline Iran & 450 & 1,007 & 15,517 & 1,000 & 193,221 & 263,420 \\
\hline Iraq & 1,700 & 4,100 & 49,641 & 500 & 6,400 & 22,838 \\
\hline Israel & 0 & 0 & 25 & 0 & -6 & -6 \\
\hline Jordan & 0 & -2 & -47 & 0 & 0 & 1,000 \\
\hline Kuwait' ${ }^{1}$ & 0 & 500 & 16,926 & 0 & 500 & 12,814 \\
\hline Oman & 0 & 921 & 2,090 & 0 & 605 & 2,581 \\
\hline Qatar & 0 & 50 & 460 & 0 & 25 & $-148,535$ \\
\hline Ras Al Khaimah & 0 & 0 & 0 & 0 & $-3,900$ & $-3,900$ \\
\hline Saudi Arabia' & $-3,187$ & -88 & 11,821 & $-416,146$ & $-1,646$ & 8,389 \\
\hline Sharjah & 0 & 0 & 14 & 0 & 0 & 493 \\
\hline Syria & 0 & 370 & 298 & 0 & 250 & 1,150 \\
\hline Turkey & 2 & 162 & 135 & 0 & -39 & 329 \\
\hline Umm Al Qaiwain & 0 & 0 & 0 & 0 & 0 & 250 \\
\hline Yemien & 0 & 853 & 1,303 & 0 & 7,800 & 11,300 \\
\hline Tolal & $-1,035$ & 8,537 & 126,082 & $-414,456$ & 205,860 & 208,337 \\
\hline \multicolumn{7}{|l|}{ Africa } \\
\hline Algeria & 30 & 1,057 & 966 & 3 & $-1,535$ & 24,770 \\
\hline Angola & 28 & 568 & 822 & 10 & 3,420 & 3,454 \\
\hline Benin & 0 & 3 & $\cdot 80$ & 0 & 0 & 0 \\
\hline Cameroon & 0 & 0 & 29 & 0 & 0 & $-1,157$ \\
\hline Chad & 10 & 15 & 94 & 0 & 0 & 0 \\
\hline Congo & 62 & 134 & 502 & 96 & 127 & .945 \\
\hline Cote D'Ivoire & 0 & 1 & -74 & 0 & -344 & 486 \\
\hline Egypt & 96 & 401 & 766 & 116 & 3,278 & 8,744 \\
\hline Ethiopia & 0 & 0 & 0 & 0 & 0 & 850 \\
\hline Gabon & 22 & 181 & -140 & 5 & 97 & -436 \\
\hline Ghana & 0 & 0 & 5 & 0 & 1 & 2 \\
\hline Guinea Fquatorial & 0 & 0 & 0 & 0 & 0 & 802 \\
\hline Libya & 1,302 & 827 & $-3,709$ & 146 & 3,318 & 4,004 \\
\hline Morocco & 0 & 0 & 10 & 0 & -9 & 28 \\
\hline Namibia & 0 & 0 & 0 & 0 & 0 & 1,700 \\
\hline Nigeria & -80 & 111 & -905 & 1,137 & 13,145 & 66,655 \\
\hline Senegal & 0 & 0 & -90 & 0 & 0 & 15 \\
\hline So. Africa & 0 & 19 & 20 & 90 & 636 & 636 \\
\hline Sudan & 0 & 0 & 327 & 0 & 0 & 839 \\
\hline Tanzania & 0 & 0 & 0 & 0 & $-6,090$ & $-6,090$ \\
\hline Tunisia & -140 & -183 & -299 & 0 & -61 & $-1,048$ \\
\hline Zaire & 0 & 11 & -42 & 0 & 1 & 2 \\
\hline Total & 1,330 & 3,145 & $-1,798$ & 1,603 & 15,984 & 103,311 \\
\hline
\end{tabular}

Soo footnoter at and of tablo 
Table B1. Modifled Petroconsultants Reserve Additions (Continued)

\begin{tabular}{|c|c|c|c|c|c|c|}
\hline \multirow[b]{2}{*}{ Country } & \multicolumn{3}{|c|}{ Oll, MMbbls } & \multicolumn{3}{|c|}{ Natural Gas, Bcf } \\
\hline & $\begin{array}{c}\text { Last } 3 \\
\text { Months } \\
4 / 90-6 / 90\end{array}$ & $\begin{array}{c}\text { Last } 12 \\
\text { Months } \\
7 / 89-6 / 90\end{array}$ & $\begin{array}{c}\text { Last } 36 \\
\text { Months } \\
7 / 87-6 / 90\end{array}$ & $\begin{array}{c}\text { Last } 3 \\
\text { Months } \\
4 / 90-6 / 90\end{array}$ & $\begin{array}{c}\text { Last } 12 \\
\text { Months } \\
7 / 89-6 / 90\end{array}$ & $\begin{array}{c}\text { Last } 36 \\
\text { Months } \\
7 / 87-6 / 90\end{array}$ \\
\hline \multicolumn{7}{|l|}{ Asia-Pacific } \\
\hline Australia & -109 & 411 & 951 & 445 & 1,640 & 5,924 \\
\hline Bangladesh & 0 & 0 & 2 & 0 & 800 & 3,053 \\
\hline Brunei & 20 & 37 & 876 & 100 & -520 & 4,331 \\
\hline China & 2,109 & 4,929 & 10,380 & 2,482 & 4,486 & 10,790 \\
\hline India & -205 & 137 & 549 & 200 & -19 & 1,418 \\
\hline Indonesla & -119 & 103 & 1,936 & $-1,726$ & $-1,747$ & 66,552 \\
\hline Japan & 5 & 18 & 73 & 0 & 81 & 396 \\
\hline Malaysia & 7 & 320 & 902 & $-1,790$ & $-2,370$ & $-7,064$ \\
\hline Myanmar (Burma) & 1 & $-3,006$ & 81 & 0 & 162 & 934 \\
\hline New Zealand & 0 & 17 & 52 & 567 & 640 & 823 \\
\hline Pakistan & 14 & 119 & 256 & 178 & 2,225 & 4,785 \\
\hline Papua New Guinea & 0 & 120 & 185 & 550 & 1,030 & 4,406 \\
\hline Philippines & -1 & 5 & 39 & -70 & 605 & 331 \\
\hline So. Korea & 0 & 0 & 0 & 0 & 190 & 200 \\
\hline Taiwan & 0 & 0 & 11 & -97 & -101 & -83 \\
\hline Thailand & -1 & 7 & 10 & 167 & 419 & 4,347 \\
\hline Vietnam & -1 & 39 & $-1,905$ & -45 & -5 & 75 \\
\hline Total & 1,720 & 3,256 & 14,398 & 961 & 7,516 & 101,218 \\
\hline Total OPEC & 337 & 8,418 & 141,133 & $-411,612$ & 216,009 & 367,596 \\
\hline Total Non-OPEC ME & -8 & 6,346 & 47,173 & 6,528 & 34,590 & 155,677 \\
\hline Total CPE & 2,108 & 9,890 & 18,167 & 2,482 & $-41,995$ & 28,082 \\
\hline Total & 2,437 & 24,654 & 206,473 & $-402,602$ & 208,604 & 551,355 \\
\hline
\end{tabular}

'Includes one-half of the reserve additions in the Neutral Zone.

Note: A listing of OPEC, CPE, and ME countries is contained in the Glossary. Column totals may not add due to independent rounding.

Source: Petroconsultants, S.A. with some historical data from Appendix A not present in Petroconsultants. 
Appendix C

World Oil and Natural Gas Reserves 


\section{Appendix C}

Table C1. World Oll and Natural Gas Reserves

\begin{tabular}{|c|c|c|c|c|}
\hline \multirow[b]{2}{*}{ Region/Country } & \multicolumn{2}{|c|}{$\begin{array}{c}\text { Oll } \\
\text { (Billion Barrels) }\end{array}$} & \multicolumn{2}{|c|}{$\begin{array}{c}\text { Natural Gas } \\
\text { (Trillion Cublc Feet) }\end{array}$} \\
\hline & $\begin{array}{c}\text { Oll \& Gas } \\
\text { Journal } \\
12 / 31 / 89 \\
\end{array}$ & $\begin{array}{c}\text { World } \\
\text { Oil } \\
12 / 31 / 89 \\
\end{array}$ & $\begin{array}{c}\text { Oll \& Gas } \\
\text { Journal } \\
12 / 31 / 89 \\
\end{array}$ & $\begin{array}{c}\text { Woild } \\
\text { Oll } \\
12 / 31 / 89 \\
\end{array}$ \\
\hline \multicolumn{5}{|l|}{ North America } \\
\hline Canada & 6.1 & 6.8 & 94.3 & 97.0 \\
\hline Mexico & 56.4 & 52.0 & $73: 4$ & \%27 \\
\hline United States' & 26.5 & 26.5 & 175.4 & 175.4 \\
\hline Other & 0,0 & 0.2 & 00 & 00 \\
\hline Total & 89.0 & 85.4 & 343.1 & 345.2 \\
\hline \multicolumn{5}{|l|}{ South America } \\
\hline Argentina & 2.3 & 2.2 & 27.3 & 26.3 \\
\hline Bolivia & 0.2 & 0.2 & 56 & 87 \\
\hline Brazil & 2.8 & 2.8 & 3.8 & 4.1 \\
\hline Chlle & 0.3 & 0.3 & $\begin{array}{r}42 \\
\end{array}$ & 41 \\
\hline Colombia & 2.1 & 2.0 & 4.0 & 4.0 \\
\hline Eouador & 1.5 & 1.4 & 40 & 40 \\
\hline Peru & 0.4 & 0.8 & 0.7 & 0.7 \\
\hline Trinidad and Tobago & 0.5 & 0.6 & 100 & 8.7 \\
\hline Venezuela & 58.5 & 60.5 & 100.8 & 105.7 \\
\hline Other & 0.0 & 0.0 & 00 & $0: 0$ \\
\hline Total & 68.6 & 70.8 & 160.3 & 163.3 \\
\hline \multicolumn{5}{|l|}{ Western Europe } \\
\hline Austria & 0.1 & 0.1 & 0.4 & 0.4 \\
\hline Denmark & 0.8 & 0.5 & 4.5 & 3.0 \\
\hline France & 0.2 & 0.2 & 1.2 & 1.3 \\
\hline Germany, West & 0.4 & 0.2 & $6 ; 6$ & 6.4 \\
\hline Greace & 0.1 & 0.0 & 0.2 & 0.0 \\
\hline Italy & 0.7 & 0,7 & 117 & 11,6 \\
\hline Netherlands & 0.2 & 0.2 & 61.1 & 60.9 \\
\hline Nonway & 11.5 & 11.0 & 82.2 & 931 \\
\hline Spain & 0.0 & 0.0 & 0.8 & 0.2 \\
\hline United Kingdom & 4.3 & 3.8 & 20.8 & $19: 8$ \\
\hline Other & 0.0 & 0.0 & 0.0 & 0.8 \\
\hline Tolal & 18.3 & 16.8 & 189.5 & 197.6 \\
\hline \multicolumn{5}{|l|}{ Eastern Europe } \\
\hline U.S.S.A. & 58.4 & 57.9 & $1,500.0$ & $1,550.0$ \\
\hline Other ${ }^{2}$ & 1.7 & 1.9 & 28.0 & $21: 0$ \\
\hline Tolal & 60.1 & 59.8 & $1,528.0$ & $1,571.0$ \\
\hline \multicolumn{5}{|l|}{ Middle East } \\
\hline Abu Dhabi & 92.2 & 54.4 & 182.9 & 182.7 \\
\hline Bahrain & 0.1 & 0.1 & 6.5 & $6: 3$ \\
\hline Dubai & 4.0 & 1.3 & 4.9 & 1.7 \\
\hline Iran & 92.9 & 62.5 & 500.0 & $600: 0$ \\
\hline Iraq & 100.0 & 100.0 & 95.0 & 110.0 \\
\hline Jordan & 0.0 & 0.0 & 0.1 & 0.4 \\
\hline Kuwait & 97.1 & 98.4 & 54.6 & 52.6 \\
\hline Oman & 4.3 & 4.3 & 9.3 & 9.9 \\
\hline Qatar & 4.5 & 2.6 & 163.1 & 162.0 \\
\hline Saudi Arabla ${ }^{3}$ & 257.6 & 262.5 & 187.3 & 188.4 \\
\hline Syria & 1.7 & 2.0 & 4.0 & 5.5 \\
\hline Turkey & 0.5 & 0.3 & 0.7 & 0.7 \\
\hline Yemen & 4.0 & 4.3 & 5.5 & 12.0 \\
\hline Other & 1.9 & 0.0 & 13.0 & 9.0 \\
\hline Tolal & 660.8 & 592.8 & $1,226.9$ & $1,341,2$ \\
\hline
\end{tabular}

See footnotes at end of tabie. 


\begin{tabular}{|c|c|c|c|c|}
\hline \multirow[b]{2}{*}{ Reglon/Country } & \multicolumn{2}{|c|}{$\begin{array}{c}\text { Oll } \\
\text { (Billion Barrels) }\end{array}$} & \multicolumn{2}{|c|}{$\begin{array}{c}\text { Natural Gas } \\
\text { (Trillion Cubic Feet) }\end{array}$} \\
\hline & $\begin{array}{c}\text { Oll \& Gas } \\
\text { Journal } \\
12 / 31 / 89\end{array}$ & $\begin{array}{c}\text { World } \\
\text { Oil } \\
12 / 31 / 89\end{array}$ & $\begin{array}{c}\text { Oll \& Gas } \\
\text { Journal } \\
12 / 31 / 89\end{array}$ & $\begin{array}{c}\text { World } \\
\text { Oll } \\
12 / 31 / 89\end{array}$ \\
\hline \multicolumn{5}{|l|}{ Atrica } \\
\hline Algeria & 9.2 & 9.2 & 114.0 & 114.2 \\
\hline Angola & 2.0 & 2.1 & 2.1 & 1.8 \\
\hline Cameroon & 0.4 & 0.5 & 3.9 & 3.8 \\
\hline Congo & 0.8 & 0.7 & 2.6 & 2.5 \\
\hline Egypt & 4.5 & 4.3 & 11.7 & 11.5 \\
\hline Gabon & 0.7 & 1.0 & 0.6 & 0.5 \\
\hline Libya & 22.8 & 22.8 & 25.5 & 29.2 \\
\hline Morocco & 0.0 & 0.0 & 0.1 & 0.1 \\
\hline Nigeria & 16.0 & 16.7 & 87.4 & 47.4 \\
\hline South Africa & 0.0 & 0.0 & 1.8 & 1.5 \\
\hline Tunisia & 1.8 & 1.8 & 3.1 & 3.1 \\
\hline Other & 0.6 & 1.7 & 14.0 & 6.0 \\
\hline Total & 58.8 & 60.8 & 266.7 & 221.6 \\
\hline \multicolumn{5}{|l|}{ Asla-Pacific } \\
\hline Australia & 1.7 & 2.8 & 16.5 & 73.5 \\
\hline Brunel & 1.4 & 1.2 & 11.4 & 12.2 \\
\hline China & 24.0 & 21.5 & 35.3 & 33.0 \\
\hline India & 7.5 & 4.3 & 23.0 & 20.9 \\
\hline Indonesia & 8.2 & 12.0 & 87.0 & 85.7 \\
\hline Japan & 0.1 & 0,0 & 1.1 & 1.3 \\
\hline Malaysia & 3.0 & 3.7 & 51.9 & 53.6 \\
\hline Myanmar (Burma) & 0.1 & 0.2 & 9.4 & 5.1 \\
\hline New Zealand & 0.1 & 0.2 & 5.1 & 4.0 \\
\hline Paklstan & 0.1 & 0.3 & 18.0 & 23.0 \\
\hline Taiwan & 0.0 & 0.0 & 0.8 & 0.6 \\
\hline Thalland & 0.2 & 0.3 & 6.9 & 14.5 \\
\hline Other & 0.2 & 0.3 & 16.9 & 18.4 \\
\hline Total & 46.5 & 46.8 & 283.3 & 345.7 \\
\hline Total OPEC & 767.1 & 705.3 & $1,620.2$ & $1,693.2$ \\
\hline Tolal Non-OPEC ME & 151.0 & 146.5 & 814.3 & 888.3 \\
\hline Total CPE & 84.1 & 81.3 & $1,563.3$ & $1,604.0$ \\
\hline World Total & $1,002.2$ & 933.1 & $3,997.8$ & $4,185.5$ \\
\hline
\end{tabular}

'United States reserves are from Energy Information Administration, U.S. Crude OIl, Natural Gas, and Natural Gas Liquids Reserves, 1989 Annual Report.

${ }^{2}$ Oil and Gas Journal includes Albania, Bulgaria, Cuba, Czechoslovakia, East Germany, Hungary, Mongolia, North Korea, Poland, Romania, Yugoslavia, and Vietnam. World Oil includes Albania, Bulgaria, Czechoslovakia, East Germany, Hungary, Poland, Romania, and Yugoslavla. ${ }^{3}$ Includes one-halt of the reserves in the Neutral Zone.

Note: Column totals may not add due to independent rounding.

Sources: PennWell Publishing Company, Oil and Gas Journal, December 25, 1989, pp, 44-45. Gulf Publishing Company, World Oil, August, 1990, p. 26. The Energy Information Administration does not certify these international reserves data but reproduces the information as a matter of convenience for the reader. 
Glossary 


\section{Glossary}

\section{Abbreviations}

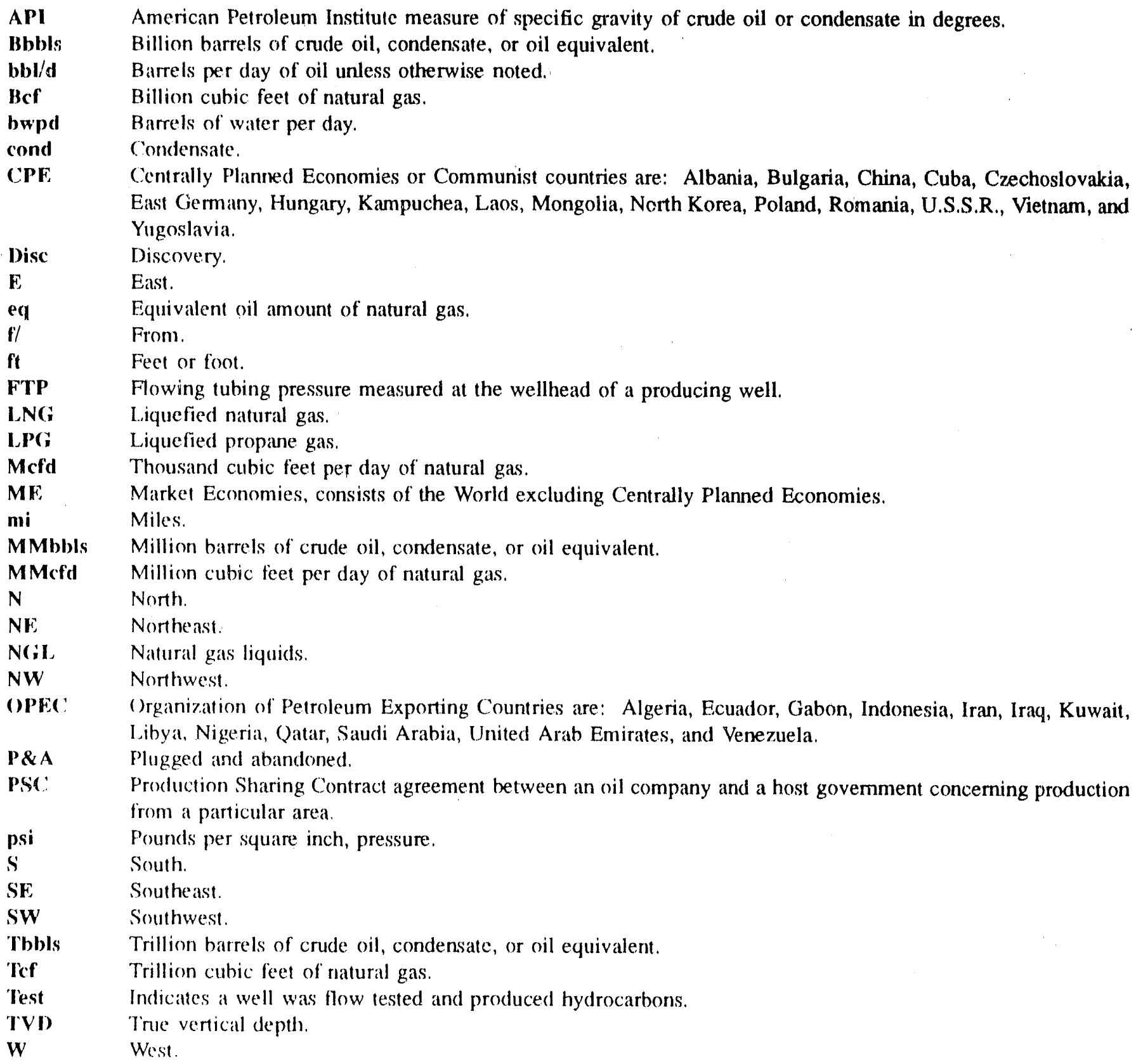




\section{Your Entrée to}

Federal Statistics!

\section{CENSUS \\ CATALOG AND GUIDE: 1990}

\section{Helps you select from all the products}

Every Census Bureau product issued mid-1988--1989:

Reports Microfiche Computer tapes CD-ROM

Maps Floppy disks Online access

Key statlstical publications from other Federal agencles (NEW!)

Features facts about each product

Topics Areas Dates Prices

\section{Makes finding the right product easy}

Extensive overview chapter Title index

Detailed subject index Guides to each statistical subject

Identifies sources of assistance

1,400 State Data Center organizations

200 Census Bureau specialists

1,500 depository libraries

Other Federal statistical agencies

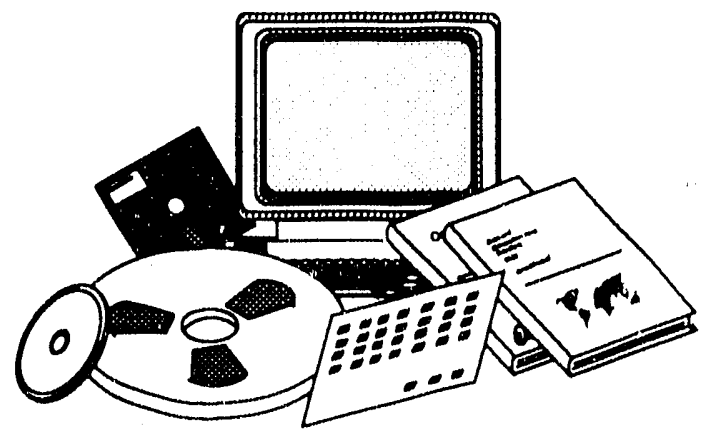

4 other directory lists

\section{*6835 Superintendent of Documents Publication Order Form}

Yes, please send me: copies of Census Catalog and Gulde: 1990 at $\$ 14, \mathrm{~S} / \mathrm{N} 003-024-07169 \cdots$.

1. The total cost of my order is $\$$

(International customers please add $25 \%$ ) All prices include regular domestic postage and handling and are good through 1/91. After this date, please call Order and Information Desk at 202-783-3238 to verify prices.

\section{Contents}

General and Reference

Agriculture

Business

Construction and Housing

Foreign Trade

Geography

Governments

International

Manufacturing and Mineral Industries

Population

Transportation

1990 Census Product Plans (NEWI)

Sources of Assistance

Factfinder Guides
2. Please Type or Print

(Company or personal name)

(Additional address/attention line)

(Street address)

(City, State, ZIP Code)

(Daytime phone including area $\operatorname{cod} \theta$ )

\section{Please Choose Method of Payment:}

1 Check payable to the Superintendent of Documents GPO Deposit Accourit

VISA or MasterCard Account

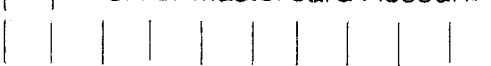

(Credit card expiration date)
Charge your older

It's easy!

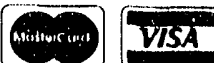

Mall To: Superintendent of Documents, Government Printing Office, Washington, DC 20402-9325 

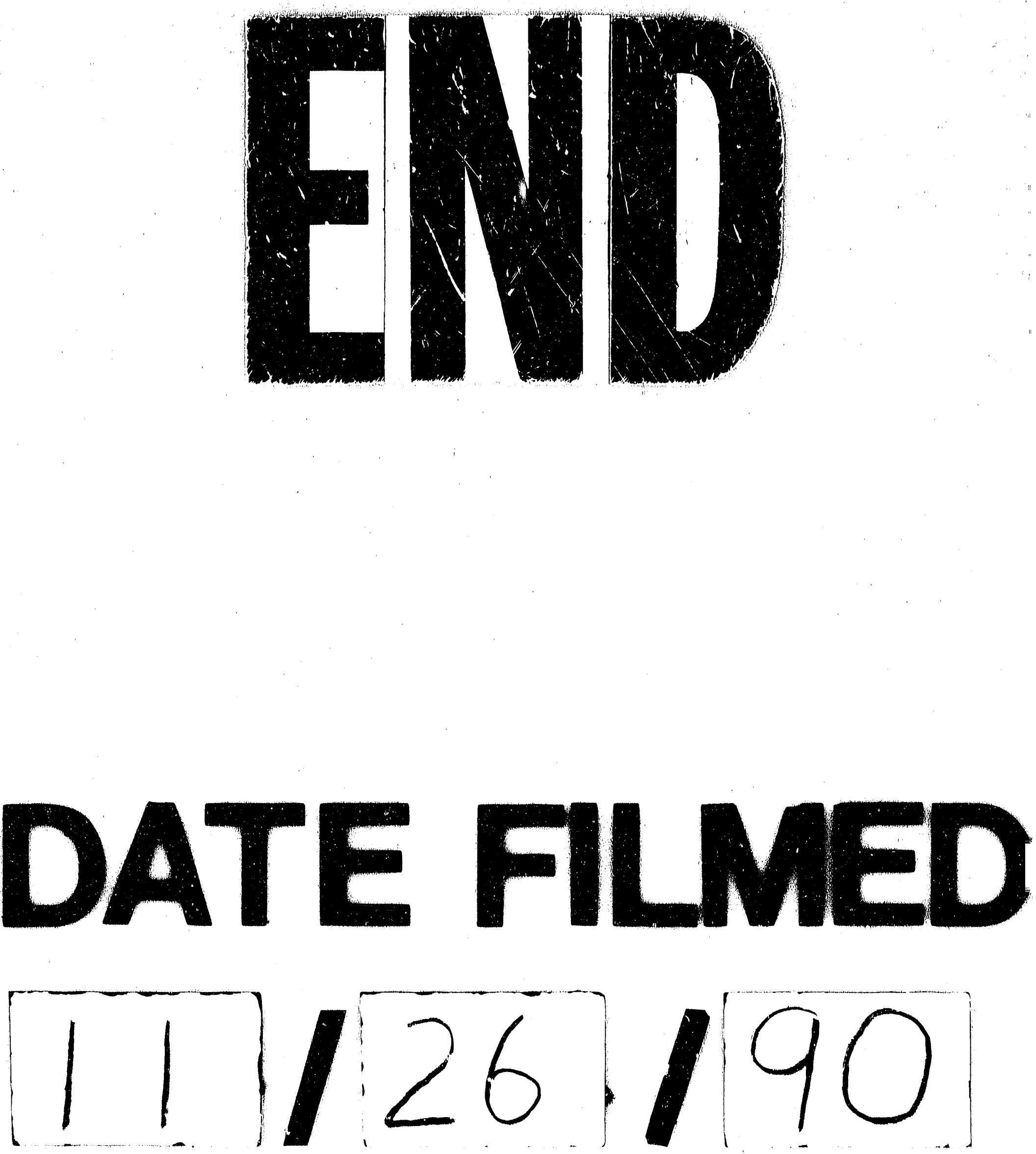
